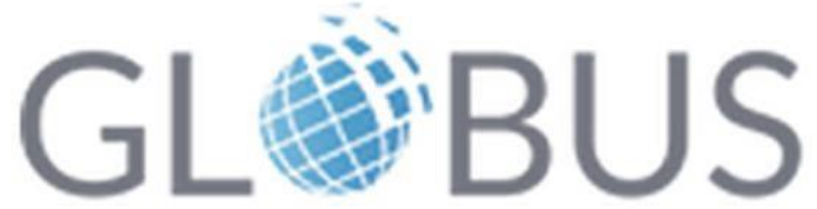 \\ научные журналы
}

\author{
НАУЧНЫЙ ЖУРНАЛ "GLOBUS" \\ МУЛЬТИДИСЦИПЛИНАРНЫЙ \\ СБОРНИК НАУЧНЫХ ПУБЛИКАЦИЙ
}

«ДОСТИЖЕНИЯ И ПРОБЛЕМЫ СОВРЕМЕННОЙ НАУКИ»

ВЫПУСК 7 (40)

(03 июля 2019г.)

г. Санкт-Петербург- 2019

(C) Научный журнал "Globus" 
УДК 082

ББК 94.3

ISSN: $2658-5197$

Редакционная коллегия:

Кежинбаева.А.М канд. экон. наук профессор Фролов М.Г канд. мед. наук Научный сотрудник

Гамбарян.О,А д-р психол. наук Старший научный сотрудник

Максимов В.П канд. техн. наук Преподаватель

Герман А.О доцент

Сборник публикаций научного журнала "Globus" «Достижения и проблемы современной науки» Выпуск 7 (40) г. Санкт-Петербурга: сборник со статьями (уровень стандарта, академический уровень). - С-П.: Научный журнал "Globus", 2019. - 156c.

Тираж - 300 экз.

УДК 082

ББК 94.3

ISSN: 2658-5197

Издательство не несет ответственности за материалы, опубликованные в сборнике. Все материалы поданы в авторской редакции и отображают персональную позицию участника конференции.

Контактная информация организационного комитета конференции:

Научный журнал "Globus"

Электронная почта: info@globus-science.ru

Официальный сайm: www.globus-science.ru 


\section{СОДЕРЖАНИЕ}

\section{ВЕТЕРИНАРНЫЕ НАУКИ}

Саввинова М. С.

ОПТИМИЗАЦИЯ ПАРАМЕТРОВ МИКРОКЛИМАТА ПТИЧНИКОВ В УСЛОВИЯХ КРИОЛИТОЗОНЫ 5

\section{ИСТОРИЧЕСКИЕ НАУКИ}

Бродникова А. Д.

АГИТАЦИОННАЯ БОРЬБА МЕЖДУ РУССКОЙ ПРАВОСЛАВНОЙ ЦЕРКОВЬЮ И СОВЕТСКОЙ ВЛАСТЬЮ НА СТРАНИЦАХ ПЕРИОДИЧЕСКОЙ ПЕЧАТИ В 1917-1922 ГГ. (ПО МАТЕРИАЛАМ ЕНИСЕЙСКОЙ ГУБЕРНИИ)......9

\section{кУЛЬТУРоЛогИя}

\section{Сu Юŭ}

АНАЛИЗ ПУТИ РАЗВИТИЯ ПУБЛИЧНОГО ОБРАЗА КИТАЙСКОГО УШУ С ТОЧКИ ЗРЕНИЯ «МАСС» 13

\section{МЕДИЦИНСКИЕ НАУКИ}

Искандаров Т. И., Романова Л.Х.,

Славинская Н. В., Искандарова Г. Т.

КРИТЕРИИ БЕЗОПАСНОГО ПРИМЕНЕНИЯ ДЕФОЛИАНТА ХЛОПЧАТНИКА «ФАНБАРАКА» В СЕЛЬСКОМ ХОЗЯЙСТВЕ

\section{ПЕДАГОГИЧЕСКИЕ НАУКИ}

Гребеникова Н. Г.

ФОРМИРОВАНИЕ ПРЕДСТАВЛЕНИЙ О ВРЕМЕНАХ ГОДА У ДЕТЕЙ СТАРШЕГО ДОШКОЛЬНОГО ВОЗРАСТА 19 Колчанов А.Л.

ШКОЛЬНАЯ СРЕДА КАК УСЛОВИЕ АККУЛЬТУРАЦИИ ДЕТЕЙ-МИГРАНТОВ (ИНОФОНОВ) НА ПРИМЕРЕ ШКОЛЫ № 36 Г. ПЕРМИ.

Ноздрякова Е. В.

ОСОБЕННОСТИ РАЗВИТИЯ КОММУНИКАТИВНОЙ КОМПЕТЕНТНОСТИ ОБУЧАЮЩИХСЯ В ИНТЕРАКТИВНОМ ОБРАЗОВАТЕЛЬНОМ ПРОЦЕССЕ.

Бартаева П.П.

ПОЗНАВАТЕЛЬНО ИССЛЕДОВАТЕЛЬСКАЯ ДЕЯТЕЛЬНОСТЬ В ДОО

Тазетдинова Е. $\mathrm{H}$.

НЕОБХОДИМОСТЬ И ВОЗМОЖНОСТИ ФОРМИРОВАНИЯ ГРАЖДАНСКОЙ ИДЕНТИЧНОСТИ ОБУЧАЮЩИХСЯ КОЛЛЕДЖА

Ушакова О. А.

РАЗВИТИЕ ИГРОВОЙ ДЕЯТЕЛЬНОСТИ СТАРШИХ ДОШКОЛЬНИКОВ СРЕДСТВАМИ ИНТЕРАКТИВНОГО ТЕАТРА

\section{ПОЛИТИЧЕСКИЕ НАУКИ}

Саенко П. А., Шабуров А. С.

ВОЙНА - ПРОДОЛЖЕНИЕ ПОЛИТИКИ, В ТОМ ЧИСЛЕ ЖЕНСКИМИ РУКАМИ 45

\section{ПСИХОЛОГИЧЕСКИЕ НАУКИ}

Трушкова С. В., Калашникова Д. Д.

СТРАТЕГИИ ПРЕОДОЛЕНИЯ СТРЕССА С УЧЁТОМ ТЕМПЕРАМЕНТА РАБОТНИКА. 


\section{СОЦИОЛОГИЧЕСКИЕ НАУКИ}

Ян Цзе

СОЦИАЛЬНО-ДЕМАГРАФИЧЕСКАЯ СТРУКТУРА В ТАДЖИКСКОЙ РЕСПУБЛИКЕ

.54

\section{ТЕХНИЧЕСКИЕ НАУКИ}

Долгов Ю. А.,

Балашова Ю. В., Терещенко Е. В.

АЛГОРИТМ ПОДГОТОВКИ ТАБЛИЦЫ МНОГОМЕРНЫХ ПАССИВНЫХ ЭКСПЕРИМЕНТАЛЬНЫХ ДАННЫХ ДЛЯ ПОЛУЧЕНИЯ АДЕКВАТНЫХ МАТЕМАТИЧЕСКИХ МОДЕЛЕЙ

Сергеев A. B.

РАЗРАБОТКА МОДЕЛИ УПРАВЛЕНИЯ ПРОИЗВОДСТВЕННОЙ СИСТЕМОЙ НА БАЗЕ КЛАССИЧЕСКОЙ ТЕОРИИ АВТОМАТИЧЕСКОГО УПРАВЛЕНИЯ

Труфанова И. С., Попова Ю. М.

ОСОБЕННОСТИ ПРИМЕНЕНИЯ ТРАНСПОРТНОЙ СИСТЕМЫ RAIL-VEYOR .67

\section{ФИЛОЛОГИЧЕСКИЕ НАУКИ}

Балута A. A.

ИМЯ ДЕЙСТВИЯ/ДЕЯТЕЛЯ В ДРЕВНИХ И НОВЫХ ИНДОЕВРОПЕЙСКИХ И СЕМИТСКИХ ЯЗЫКАХ. .71

Краутман Т. Е.

ГРАММАТИЧЕСКИЕ ТРАНСФОРМАЦИИ ПРИ ПЕРЕВОДЕ ТЕКСТА ЗАКОНА С АНГЛИЙСКОГО ЯЗЫКА НА РУССКИЙ

\section{ЭКОНОМИЧЕСКИЕ НАУКИ}

Исаев M.X.

РАЗВИТИЕ САМОЗАНЯТОСТИ НАСЕЛЕНИЯ КАК ПУТЬ РЕШЕНИЯ ПРОБЛЕМЫ ЗАНЯТОСТИ .76

Эглит Я.Я.,

Андорская А.В., Шаповалова М. И.

Перспективы перевозок скоропортящихся грузов в России .78

\section{ЮРИДИЧЕСКИЕ НАУКИ}

Кулинич В. В.,

Белова С. Л., Чапурко Т. М.

СОВРЕМЕННЫЕ ПРОБЛЕМЫ ПРАВОПРИМЕНИТЕЛЬНОЙ ДЕЯТЕЛЬНОСТИ В СФЕРЕ УГОЛОВНО-ПРАВОВОЙ ОХРАНЫ ПРАВ И ИНТЕРЕСОВ НЕСОВЕРШЕННОЛЕТНИХ С ПОЗИЦИЙ ВВЕДЕНИЯ «УГОЛОВНОГО ПРОСТУПКА» В ДЕЙСТВУЮЩЕЕ УГОЛОВНОЕ ЗАКОНОДАТЕЛЬСТВО 


\title{
ВЕТЕРИНАРНЫЕ НАУКИ
}

\section{УДК 637.4:614.31 \\ ОПТИМИЗАЦИЯ ПАРАМЕТРОВ МИКРОКЛИМАТА ПТИЧНИКОВ В УСЛОВИЯХ КРИОЛИТОЗОНЫ}

\author{
Саввинова Маргарита Семеновна \\ профессор, \\ доктор ветеринарных наук, \\ ФГБОУ ВО Якутская государственная сельскохозяйственная академия, \\ профессор кафедры ветеринарно-санитарной экспертизы и гигиены \\ 2. Якутск
}

\begin{abstract}
Промышленное птицеводство, как самая наукоемкая и динамичная отрасль агропромышленного комплекса, вносит весомый вклад в обеспечение населения развитых стран продовольствием $[2,4]$.

Практика деятельности птицеводческих предприятий на Крайнем Севере свидетельствует о необходимости оптимизации параметров микроклимата при помощи эффективных систем обеспечения микроклимата[1, 3].

Изыскание научно-обоснованных оптимальных норм в условиях Крайнего Севера для условий обитания сельскохозяйственных животных и птиц с целью повышения неспецифической устойчивости организма всегда было крайне актуальной задачей в разработке системы мероприятий по обеспечению ветеринарного благополучия и получения высококачественной продукции [3].

Цель работы - разработка мероприятий по оптимизации параметров микроклимата птичников в экстремальных условиях криолитозоны.

Для достижения поставленной цели были поставлены следующие задачи:

- изучить условия содержания кур-несушек в условиях Якутии;

- провести ветеринарно-гигиенические исследования микроклимата птичников в разные периоды года;

- определить влияние микроклимата на естественную резистентность, продуктивность и сохранность
\end{abstract} птиц.

Работу выполняли в условиях ОАО «Якутская птицефабрика», на базе клинико-диагностической лаборатории кафедры ветеринарно-санитарной экспертизы и гигиены с использованием общепринятых методов зоогигиенических исследований. Методы исследования: для промера показаний микроклимата использованы приборы «Метеометр М-17» и ТК-3 БКМ - модель 41, газоанализатор универсальный УГ-2. Опытную и контрольную группы птиц выбирали по принципу аналогов. Опыты проведены на курахнесушках породы Нy Line. Опытная группа птиц содержалась в условиях нововведенной энергосберегающей системы вентиляции для оптимизации параметров микроклимата, а контрольная группа птиц - в условиях работы традиционной вентиляционной системы.

В результате ветеринарно-гигиенической оценки микроклимата в птичниках птицефабрики г. Якутска для улучшения его параметров нами были рекомендованы следующие мероприятия, которые внедрены в производство:

- реконструкция одноэтажных птичников с напольным содержанием птицы в клеточное многоярусное для облегчения обслуживания и регулирования параметров микроклимата, повышения сохранности и продуктивности птицы;

- реконструкция вентиляционно-отопительной системы в птичниках с использованием электрокалориферов типа СФО для обогрева воздуха и улучшения микроклимата в связи с частой поломкой водяной системы вследствие замерзания воды в теплоносителе при температуре наружного воздуха минус $30{ }^{\circ} \mathrm{C}$ и ниже.

Проект одноэтажного птичника после реконструкции по нашим предложениям представляет собой удлиненное безоконное здание. Фундамент свайный, железо-бетонный, с сохранением вечномерзлых грунтов путем устройства проветриваемого подполья. Стены из крупных стеновых керамзито-бетонных блоков, внутренние стены и перегородки - кирпичные, полы в помещении основного назначения цементные, в остальном - цементно-бетонные. Покрытие совмещенное, рулонная кровля сборными железобетонными плитами.

Каждый производственный зал оборудован приточно-вытяжной вентиляцией с механическим побуждением воздуха. Приточная вентиляция ЦМ-6 подает воздух через калориферы КФС-8. Воздуховоды приточной вентиляции расположены по верхней части зала и идут по всей длине зала. Удаление отработанного воздуха из зала предусмотрено при помощи вентиляторов ВО-7, расположенных в нижней части продольных и торцовых стен здания.

Яйценоскость кур после реконструкции вентиляционно-отопительной системы повысилась от 208 до 250 штук в год от одной курицы. Внедрение новой технологии производства, применение безоконного 
содержания с регулируемым световым режимом и в связи с этим резкое улучшение микроклимата в птичниках позволило увеличить производство яиц в целом по птицефабрике до 48 млн штук в год.

Применение клеточного содержания без расширения производственных площадей улучшило условия труда работников и содержания птицы, увеличило мощность предприятия, сократило количество обслуживающего персонала и расходы на отопление помещений, снизило затраты труда и кормов на единицу продукции. Производительность труда повысилась в 2,5 раза, прибыль птицефабрики возросла. Благодаря клеточному содержанию птицы сохранность взрослого поголовья повысилась с 95,6 до 98,8 \%, а молодняка - с 90 до $96 \%$.

При переходе на клеточное содержание переоборудование систем для создания оптимального микроклимата вызвало большое опасение у специалистов птицефабрики. Несмотря на жестокие морозы для удаления вредных веществ и излишней влаги за один час нужно обновить воздух помещения в полтора раза. Это значит, что если общая площадь птичника составляет 5 тыс. м², то за час из него необходимо удалить и, соответственно, подать взамен 7,5 тыс. м³ наружного воздуха. В зимний период надо его еще подогреть от минус $40-45^{\circ} \mathrm{C}$ до плюс $16-18^{\circ} \mathrm{C}$. При реконструкции каждого цеха по нашим предложениям менялась вентиляция и вся система обеспечения микроклимата.

Температура внутри птичников поддерживалась регулированием мощности электрокалорифера. Снижение относительной влажности воздуха производилось регулированием воздухообмена, осуществляемого изменением скорости вращения электродвигателей приточных и вытяжных вентиляторов и использованием перфорированного воздуховода в клетках. В результате проведенных нами исследований установлено, что температура воздуха внутри клеток была выше, чем в зале на 3-4 \%.

Схема системы вентиляции, рекомендованная нами для Якутской ПТФ, состояла в следующем: подача воздуха должна осуществляться в холодное время через электрический калорифер (по нашему предложению заменили водяную систему на электрическую) по четырем воздуховодам, идущим по опорным балкам от торцов здания к центру. В переходный период открываются заслонки всех приточных вентиляционных шахт, расположенных в потолочном перекрытии. В теплое время года подача воздуха - через шахты в потолочном перекрытии естественным путем. Удаление воздуха во все периоды года из нижней зоны при помощи осевых вентиляторов, вмонтированных в стеновые отверстия.

При оценке влияния регулирования температурно-влажностного и светового режимов при клеточном содержании птицы в широкогабаритных птичниках одноэтажного исполнения нами в качестве физиологических тестов были взяты гематологические показатели и продуктивность кур-несушек.

Большую концентрацию гемоглобина в крови несушек одноэтажного птичника можно объяснить повышенными адаптационными процессами и естественной резистентности организма в экстремальных условиях, меньшей стрессовой нагрузки вследствие меньших габаритов производственного зала и плотности птицы.

В переходный период года стабилизируется воздействие вечной мерзлоты на объекты окружающей среды. При этом в условиях температуры наружного воздуха $-30^{\circ} \mathrm{C}$ температура в производственных залах птичников становилась в пределах оптимальной нормы, хотя, как нами отмечено, относительная влажность в одноэтажных птичниках оказывалась выше нормы на 7,6 $\pm 1,8$ \%. Это вызвано разницей в режиме работы вентиляционно-отопительной системы (автономной - в одноэтажных). При указанных условиях микроклимата этого периода в птичниках у кур-несушек наблюдалось нарастание гемоглобина на 1,2 $\pm 0,05$ $\Gamma \%$.

В переходный период года количество лейкоцитов в крови кур, размещенных во всех типах птичников Якутской птицефабрики, было выше физиологической нормы на 2,4 \pm 0,08 \%. Однако в теплый период в условиях температуры наружного воздуха $+30 \ldots+32^{\circ} \mathrm{C}$ количество лейкоцитов уменьшалось на $1,35 \pm 0,04$ \%, что вызывалось недостаточностью воздухообмена в этих помещениях.

Результаты исследований содержания общего белка и его фракций в сыворотке крови кур-несушек показали, что концентрация общего белка находилась в пределах верхней границы нормы, а в некоторых случаях была выше ее. Это можно объяснить повышением резистентности организма птицы и адаптации в экстремальных условиях содержания.

Продуктивность кур-несушек при снижении температуры воздуха в птичниках с +12 до $+5^{\circ} \mathrm{C}$ уменьшалась на $12 \%$, а при повышении температуры до $+30^{\circ} \mathrm{C}$ падала на $28-30 \%$. При резком снижении или повышении температуры в этих помещениях установлено уменьшение яйценоскости до 50 \%.

Взрослая птица выделяла тепла по нашим данным 5,39-10,5 Вт на 1 кг живой массы. В среднем 1000 несушек (массой по 1,94 кг при нормальной плотности посадки) выделяли 10456,6 Вт тепла.

При дыхании и испражнении птицы образуются водяные пары: зимой - до 2-3 г/ч на 1 кг живой массы; летом (при высокой температуре окружающего воздуха) - до 6-7 г/ч.

Интенсивность освещения меньше влияет на продуктивность птицы, чем его продолжительность. Освещенность помещения в этом предприятии была в пределах нормы - 20-30 люксов. Освещенность во всех корпусах искусственная - при помощи люминесцентных ламп ЛБ-40, которые были подвешены в середине проходов между клеточными батареями на уровне верхнего края клетки на расстоянии 3,5-4 м друг от друга. Интенсивность света во время проведения научно-исследовательских работ была в помещении одинаковой. Для регулирования светового режима использовали автоматическую установку УПУС-1 с 
программным управлением. Продолжительность светового дня была установлена при постановке птицы на производство и выдерживался установленный график, согласно рекомендациям.

На основании проведенных нами исследований можно сделать заключение, что в условиях криолитозоны развитие птицеводства сдерживается рядом природно-экологических и экономических факторов. К их числу относятся: суровый климат с низкой среднегодовой и зимней температурой при резком колебании световой экспозиции.

В условиях Якутии нами установлено, что при поддержании оптимального температурновлажностного и светового режима резких колебаний физиологических показателей у кур-несушек не возникает. Продуктивность их была высокой. При этом состояние резистентности кур-несушек полностью зависело от основных физических показателей микроклимата, то есть от температурно-влажностного режима в птичниках, в свою очередь зависимых от влияния экстремальных условий Севера, т.е. от сильного холода в зимний и жары в летний периоды.

Относительная влажность в холодный период года имела значительные колебания и была выше допустимой на 18,2 $\pm 2,4$ \%, в переходный период превышала ее на 7,6 $\pm 1,8$ \%, а в теплый период года оказывалась, наоборот, ниже на $6,7 \pm 0,5$ \%, что было вызвано недостаточным воздухообменом, так как в холодный период под влиянием экстремальных условий среды температура воздуха снижалась ниже оптимальной и в последующем имела прямую зависимость от температуры среды.

В летний период наблюдалось увеличение запыленности и бактериальной загрязненности воздуха: в одноэтажных птичниках при условиях воздухообмена в пределах 32,06-56,75 тыс.м³/ч и 192,54-225,87 тыс/ $\mathbf{M}^{3}$.

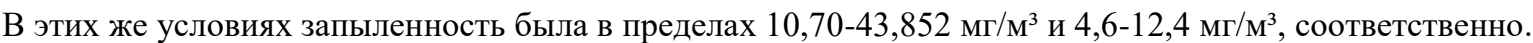
Несмотря на интенсивную бактериальную обсемененность в указанный период в многоэтажном птичнике запыленность была меньше, чем в птичниках одноэтажного исполнения, что было следствием недостаточного воздухообмена.

Среднее содержание аммиака во все периоды наблюдения в одноэтажных птичниках превышало ПДК на 3-5 мг/м.

При этом установлено, что в условиях оптимального температурно-влажностного и светового режимов резких отклонений в физиологическом показателе кур не возникало.

При этом взрослая птица выделяла углекислого газа 0,174 л/ч на 1 кг живой массы. При экстенсивном содержании птицы выделялось около 23,32-25,00 тыс. Вт тепла. В то же время при интенсивном содержании в одноэтажных птичниках соответствующие показатели составляли 93-110 тыс. Вт, а в многоэтажном только в одном зале - 250-287,46 тыс. Вт. Соответственно увеличивалось и выделение влаги: зимой до 2830 кг/ч и 108,5-110 кг/ч, летом - 140-150 кг/ч и 294-315,98 кг/ч. Одновременно резко увеличивалось количество выделяемого птицей углекислого газа: 1252,8 л/ч и 4854-8852 л/ч, что оказалось выше в 3,877,06 раза, чем в первом случае.

Из птичников в зависимости от функционального режима выбрасываются в атмосферу различные вредные вещества: вентиляционные выбросы из птичников содержат аммиак, органическую пыль и др. Другим источником образования вредных газов и запахов, кроме перечисленных, является помет в процессе его удаления, транспортировки, хранения, обработки и утилизации.

Распространение загрязняющих веществ в воздухе от Якутской птицефабрики изучали вокруг одноэтажных птичников.

Якутская птицефабрика имеет поля компостирования площадью 14 га и пометохранилище объемом 40 тыс. м². С полей компостирования, по нашим подсчетам, в атмосферу выделялось 154 т/год аммиака и 132 т/год сероводорода, а с площадки пометохранилища (с учетом его хранения без добавления других компонентов) - 7,7 т/год аммиака, 6,6 т/год сероводорода.

Как видно, большой валовый выброс загрязняющих веществ происходил с площадок компостирования и пометохранилища. Эти источники вредных веществ находились лишь в 3 км к северо-западу от населенного пункта, а господствующие ветры северного и северо-западного направления расширяли зону распространения загрязняющих веществ, т.е. аммиака и сероводорода до поселка и дачной зоны. Об этом свидетельствовали многочисленные жалобы населения.

Из одноэтажного птичника павильонной застройки, имеющего многоточечный выброс отработанного воздуха осевыми вентиляторами, в окружающую среду выбрасывается в холодный период за одни сутки 1,89 кг пыли, 1,6 тыс. м. т., 1,85 кг аммиака; в переходный соответственно 2,77 кг, 5,34 тыс. м. т., 3,85 кг; в теплый период - 12,97 кг пыли, 14,2 тыс. м.т., 12,05 кг аммиака.

Следует заметить, что в силу незначительной дальности распространения вредных веществ в атмосферном воздухе зоны Якутской птицефабрики, согласно СН 245-71 (составляющей 1 км), приземные концентрации за пределами санитарно-защитных зон птицефабрики по некоторым вредным веществам приближались к значениям ПДК. Хотя зона влияния фабрики согласно методике ОНД-86 (когда суммарное количество загрязнений атмосферы превышает 0,05 ПДК) составляла более 1000 м.

Влияние источников загрязнения Якутской птицефабрики, расположенных в зоне равнины Туймаада, значительно сказывается на санитарно-гигиеническом состоянии воздуха г. Якутска. 
Для определения фонового загрязнения, как правило, брали данные наблюдений максимально разовых концентраций вредных веществ.

Газообразные выделения (аммиак, сероводород, меркаптан и др.) контаминировали воздух в рабочих помещениях, через вентиляторы попадали в воздушный бассейн птицефабрики.

Вытяжная механическая вентиляция птичников в среднем за 1 ч подавала в атмосферу в зимний период: бактерий - 2,2 тыс. м. т., пыли - 3,75 кг, аммиака - 18 мг; весной соответственно: 3,78 тыс. м. т. На расстоянии 50 м от комплекса специфического запаха при органолептической оценке не ощущалось.

Таким образом, ширина санитарно-защитной зоны Якутской птицефабрики г. Якутска нами определена в размере 500 м от населенного пункта.

Санитарно-защитная зона изученных нами объектов может быть увеличена после мониторинга экологической системы и ветеринарно-гигиенического обоснования, но не более чем в 2 раза при неблагоприятных аэрологических условиях выбросов. Ограничение это связано особенностью ранимого ландшафта и трудностью самоочищения биосферы Крайнего Севера.

Также изучена динамика микробной контаминации птицеводческого цеха и сектора, где содержится молодняк кур. При этом установлена общая обсемененность, которая в основном представлена мезофильными аэробными факультативно-анаэробными микроорганизмами (МАФАнМ) как в воздухе, так и на поверхности, а также единичный рост плесневых и токсигенных видов грибов родов Mucor ramosissimus и Aspergillus fumigatus. Наши данные исследований позволили отнести МАФАнМ к типичным представителям спорообразующих аэробных бактерий[4].

\section{Выводы:}

1. При понижении температуры наружного воздуха до $-45^{\circ} \mathrm{C}$ и ниже температурно-влажностный режим не отвечал требованиям НТП. СХ.4-00: температура была ниже, а влажность выше, влажный холодный воздух отрицательно действовал на организм птиц. Однако после реконструкции вентиляционноотопительной системы в птичниках, когда подавался теплый подогретый воздух по периметру помещения, относительная влажность снизилась, воздух стал суше и температура в помещении повысилась, что послужило для оптимизации параметров микроклимата.

2. Относительная влажность в холодный период года имела значительные колебания и была выше допустимой на $18,2 \pm 2,4$ \%, в переходный период превышала ее на 7,6 $\pm 1,8$ \%, а в теплый период года оказывалась, наоборот, ниже на $6,7 \pm 0,5$ \%, что было вызвано недостаточным воздухообменом, так как в холодный период под влиянием экстремальных условий среды температура воздуха снижалась ниже оптимальной и в последующем имела прямую зависимость от температуры среды.

3. В условиях Якутии нами установлено, что при поддержании оптимального температурновлажностного и светового режима резких колебаний физиологических показателей у кур-несушек не возникает.

В условиях Якутии при температуре наружного воздуха $-50^{\circ} \mathrm{C}$ и ниже немаловажное значение имеет организация утеплительных работ для ограждающих конструкций, эффективная отопительная и вентиляционная система.

\section{Список использованных источников:}

1. Егорова В.С. Санитарно-гигиеническая оценка воздушной среды птичников при их реконструкции и внедрении инновационных технологий в условиях Якутии / Егорова В.С., Саввинова М.С.//Аграрный вестник Урала.- №10.- 2011.- С.18.

2. Волков Г.К. Контроль за проектированием и строительством животноводческих объектов/ Волков Г.К., Дорофеев А.А. // Ветеринария, 1971.-№ 9.- С.16.

3. Саввинова М.С. Гигиена содержания животных в природно-климатических условиях Якутии,-М.: Стерх, 2005.- 140 c.

4. Фисинин В.И. Перспективы развития птицеводства//Экономика. - 2000. - № 5.- С. 67. 


\section{ИСТОРИЧЕСКИЕ НАУКИ}

\section{АГИТАЦИОННАЯ БОРЬБА МЕЖДУ РУССКОЙ ПРАВОСЛАВНОЙ ЦЕРКОВЬЮ И СОВЕТСКОЙ ВЛАСТЬЮ НА СТРАНИЦАХ ПЕРИОДИЧЕСКОЙ ПЕЧАТИ В 1917-1922 ГГ. (ПО МАТЕРИАЛАМ ЕНИСЕЙСКОЙ ГУБЕРНИИ).}

Бродникова Алина Дмитриевна

Русская православная церковь испокон веков являлась важнейшим инструментом в руках царской власти. Государь закреплял за собой статус «помазанник божий», влияя тем самым на представления о высшей власти в русском обществе. Данная государственная политика оптимально подходила для процветания высших кругов Российской империи. Народ продолжал верить в царя, беспрекословно подчиняться, молиться за своего батюшку-царя, который является защитником русской Православной церкви, а значит и простого люда в целом. Но в 1917 г. происходит немыслимое, Церковь остаётся без своего покровителя, на смену Николаю II приходит Временное правительство, а затем советы. Русская православная церковь теперь же должна выживать самостоятельно и бороться на неравных условиях с плохо настроенной по отношению к ней новой социалистической властью.

В 1917-1922 гг. проблема взаимоотношений духовенства и правительственной власти выдвигается на первый план. Советы проводили антирелигиозную политику по отношению к церкви. Прежде всего, это объяснялась в различиях идеологических установок большевистской власти и Церкви. Объявив Церковь буржуазным институтом и главным контрреволюционером против новой власти, Советы стали вести широкую агитацию против Русской православной церкви и священнослужителей.

Такая агитация проводилась местными органами власти и активно освещалась в советской периодической печати того времени. На страницах газет Церковь выступала одним из главнейших врагов советской власти, а священнослужители разорителями рабочих и крестьян. Часто можно встретить такие заголовки, как «Попы заедают», «Попы радуются и белогвардейцы тоже», «Бессилие бога», «Нужны ли богу мельницы», «Поповская лавочка - хороший заработок», «Против богов. Как я раззнакомился с богом».

В «Деревенской правде» описывался крестный ход, который проходил в Петрограде 21 января 1918 г. В данной статье крестный ход воспринимался, как антиправительственное выступление: «Враги народа, потерпевшие поражение повсюду пробуют теперь новые средства, чтобы хоть как-нибудь возбудить народ против Советской власти». ${ }^{1}$ Указывалось, что участниками крестного хода являются по большей мере буржуазия, а также люди, которые с помощью веры прикрывали свою политику: «Сжатые кулаки по направлению к Совету, избили старика 63-х лет за то, что тот не успел снять шапку. Требовали убийства шофера, раздвинувшего для проезда автомобиля шествие. Требовали самосуда над ним, срывая злобно объявления, призывающие к спокойствию. Всё это показало, что крестный ход вовсе не веру Христову защищать, а защищать бархатные одежды тех, кто шел в середине, еле переваливаясь от жира... Мы знаем: в глухих селениях - даже там прозревают слепые. И даже там, где ещё могут избить меня за правдивое обличие жадных попов, даже там такие крестные ходы покажут народу, для чего они. И если бы Христос воскрес бы сейчас, эти жадные и корыстные служители золотого тельца убили бы его снова». ${ }^{2}$

Церковь воспринималась главной контрреволюционной силой против советской власти: «Можно признать аксиомой, что в каждом контрреволюционном заговоре найдется в качестве участника хотя бы один поп. Точно также можно считать аксиомой, что искреннее сочувствие служителей культа рабочекрестьянской власти рано или поздно приводит их к «снятию сана». Из бесчисленных примеров, интересно привести письмо Иркутского архиерея Зосимы, отрекшегося от церкви. «Сложение сана святителя, - пишет Зосима, - продиктовано мне исключительно свободной волей и собственным пониманием событий. Путем долгой работы над своей совестью я пришел к решительному выводу, что позиция, занятая православной церковью в гражданской войне с рабоче-крестьянской властью, нахождение священнослужителей в одних рядах с палачами, карателями и погромщиками непримиримо с началами христианства». ${ }^{3}$

Также в периодической печати публиковали статьи возмущенных крестьян, которые якобы столкнулись с несправедливостью и злодеяниями духовных лиц по отношению к ним. В большей степени данные статьи были направлены на грабёж общенародной собственности. В «Деревенской правде» была опубликована жалоба местного жителя, который возмущался тем, что священник проповедуют закрепить водяные мельницы за церковью, дабы не нарушать «собственность помещиков». ${ }^{4}$ Попы требовали от крестьян огромных денег и продовольствия за совершение какого-либо обряда, будь то крестины, отпевание или венчание. На страницах газет часто встречаются заголовки: «Нужна ли богу собственность?», «Нужны

\footnotetext{
${ }^{1}$ Деревенская правда. 1918. 23 января. С.1.

2 Деревенская правда. 1918. 4 февраля. С.2.

${ }^{3}$ Красноярский рабочий. 1921. 19 января. С.3.

${ }^{4}$ Деревенская правда. 1918 . 4 февраля. С.4.
} 
ли богу деньги?», и т.п. «В селе Канторке Канского уезда, священник собирает разверстку, не посылая никаких агентов. Сами крестьяне везут добровольно, да еще с поклонами. А поповская разверстка вовсе не мала: за свадьбу 2 пуда муки. Долго ли заработать попу муки 2 пуда. А вот рабочему трудновато. Крестьяне до сих пор не видят, от кого им больше пользы - от попа, который их морочит, или от рабочего - труженика, что трудится, не покладая рук. Докуда крестьяне будут откармливать паразитов, обманывающих и обирающих их. Докуда будет выполняться поповская разверстка в ущерб общегосударственной? Интересно, когда власть призывает мужичка выполнить его долг-разверстку, мужичек клянется и божится, что у него хлеба нет, что он умирает чуть-ли не сегодня сам с голода и его рабочий скот, но, когда идет за разверсткой поп, то этот же мужичек ничего не жалеет для дармоеда и смерть от него куда-то прячется». ${ }^{1}$

Советская периодическая печать пыталась внушить общественности, что церковь насильно заставляет граждан протестовать против крестьянской и рабочей власти. Под жестким натиском «попов» писались жалобы против Советов и устраивались саботажи против проводимых декретов, указывая на то, что духовенство имеет огромное влияние среди крестьян. ${ }^{2}$ Акцентировалось внимание на том, что православие - это оплот царской власти, что при самодержавии священнослужители обладали лучшими землями и не знали, что такое труд. В феврале 1921 г. был опубликован декрет Совнаркома «О порядке предоставления работы служителям религиозных культов». Данный декрет расценивался, как ещё один шаг вперёд по пути полного искоренения в Советской республике тунеядства: «Весьма обширная группа населения Республики, - так называемые - «служители религиозного культа»: ксендзы, раввины, муллы, наши попы и т.д., до сих пор жившие исключительно за счет эксплуатации народной темноты, невежества и религиозных предрассудков, привлекаются ныне к отбыванию трудовой повинности, сообразно своим силам, знаниям и способностям, наравне со всеми остальными гражданами Советской России». Они могут быть, как и все граждане, регистрируемы и посылаемы на работу учреждениями Учрабсилы. Тем не менее, Советская власть не закрыла глаза на особенные специфические качества «служителей религиозного культа» и предоставление им работы, обставила рядом ограничений и отступлений от общего порядка. Так, ввиду установленного множества фактов враждебного отношения «служителей религиозных культов к рабочекрестьянской власти и склонности их к пропаганде восстановления буржуазной государственности, с ее официальным ханжеством и лицемерием, - «служители культов» не допускаются на работу в сельские местности, а в городах и в отделы: народного образования, земледелия, рабкрина, ... и продовольствия. Затем в виду малой подготовленности к общеполезному труду и навыков к праздной жизни, установлен максимальный предел оплаты труда «служителей религиозных культов», - не выше 16-го разряда тарифных ставок. Столь же естественным представляется и требование выхода «служителей религиозных культов» на работу в гражданском одеянии, одинаковом с платьем всех трудящихся Республики, а не в каких либо особых костюмах, свидетельствующих об особом привилегированном положении «служителей», их особом избранном отличии от всей остальной трудовой массы. Ограничения эти вовсе не продиктованы какой-либо особо враждебной настроенностью Рабоче-Крестьянской власти к «служителям религиозных культов». Нет, они вполне естественны и вызваны лишь понятным стремлением обезвредить тех тайных врагов советской власти, какие, несомненно, имеются в среде «служителей религиозных культов» - стремлением защитить и оградить колеблющиеся и малосознательные элементы рабочих и крестьян от искусного влияния на их психику опытных в деле воздействия людей...Надобность в декрете уже давно назрела. Нет сомнения, что он будет встречен трудовым населением Республики с чувством живейшего удовлетворения, ибо наш принцип: «Не трудящийся да не ест» не терпит никаких исключений и уступок». ${ }^{3}$ Акцентировалось внимание на то, что советская власть попыталась уравнять духовенство с обычным народом. Но вместо того, чтобы строить новое равное и справедливое государство, священнослужители стали бороться против Советов вместе с белогвардейскими отрядами. ${ }^{4}$ Действительно, Церковь поддерживало белогвардейское правительство. Так, в 1919 г. члены Енисейского епархиального совета и служащие его канцелярии постановили отчислять с 1 февраля 1919 г. 3\% из получаемого месячного содержания на нужды армии, подобное же отчисление производилось тремя духовно-учебными заведениями города Красноярска. ${ }^{5}$ Пастыри агитировали местных жителей в необходимости своевременной и неотложной помощи на нужды армии - по мере достатка прихожан. ${ }^{6}$ Церковное правительство отправляло на фронт проповеднические отряды. Солдаты собирались в храмах, в лесу, в окопах читали молитвы, а затем вели беседы. Обсуждалась картина разрухи, до которой дошла Россия. В данных беседах искали виновников всех пережитых ужасов. Разбирались и критиковались все прокламации и агитационная литература красных, обсуждались гонения на веру, церковь и духовенство. Данные беседы проповедников производили на солдат огромное

\footnotetext{
${ }^{1}$ Красноярский рабочий.1921 . 17 февраля. С.3.

${ }^{2}$ Деревенская правда. 1918. 4 февраля. С.4.

${ }^{3}$ Красноярский рабочий . 1921. 18 февраля. С.1.

4 Деревенская правда. 1918 . 28 июня. С.2.

${ }^{5}$ Енисейские епархиальные ведомости 1919. № 4 С. 30.

${ }^{6}$ Енисейские епархиальные ведомости 1919. № 4 С. 55. 
впечатление. Особенно, когда проповеди проводили на открытом воздухе, при непрерывной артиллерийской стрельбе или в глубоких оврагах из-за обстрела местности красноармейскими отрядами. ${ }^{1}$

Также в советских газетах печатались тексты обращений священнослужителей, читаемые для прихожан. Суть таких обращений заключалась в том, что архипастыри указывали на бедственное положение России. Акцентировали внимание на разграблении святынь. И то, что большевики не пускают в храмы и запрещают молиться, называя их антихристами. Но, тут же указывали, что прихожане не были согласны с такими обвинениями против советской власти. И покидали данные собрания. ${ }^{2}$

Духовенство акцентировало внимание на том, что подвергается насилию со стороны советской власти. Например, в Епархиальных ведомостях, сообщается о донесении благочинного первого участка Ачинского уезда в епархиальный совет. Где указывалось, что священник Еловской церкви Владимир Фокин 24 января 1919 г. был захвачен шайкой большевиков - бандой Щетинкина. А 2февраля он был найден убитым и закопанным в снегу. ${ }^{3} 28$ февраля 1919 г. от начальника отряда особого назначения последовало на имя епископа Назария отношение. В нем указывалось, что благочинный пятого участка Енисейской епархии священник Трофим Кузнецов 28 января высказался против большевиков и поддержал Временное

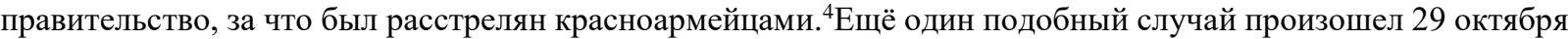
1919 г., когда на село Каратузское напали восставшие крестьяне соседних деревень с целью отобрать у казаков оружие. Казаки, спасаясь, спряталась в церкви, за что нападавшие обвинили священника М. Щербакова в участии спасения казаков и жестоко убили его. ${ }^{5}$ Священника Каргаполова отряд большевиков вывез в деревню Орловку. Заставили священнослужителя собственноручно снять с себя крест, а затем застрелили. ${ }^{6}$

Ключевым вопросом во взаимоотношениях духовенства и советской власти являлся вопрос о христианском погребении красноармейцев, которые погибли в период Гражданской войны. Так, например, в газете Минусинский край, был опубликован рапорт, который получил Енисейский епархиальный совет. В рапорте сообщалось, что местные власти запретили хоронить и поминать убитых большевиков. Енисейский епархиальный совет по этому поводу постановил, что вопрос о христианском погребении будет разрешён духовной властью. ${ }^{7}$ Также одним из священников Канского уезда был подан рапорт, в котором священнослужитель задавался вопросом у Епархиального начальства. Он не знал совершать ли погребение, отпевание и поминание лиц, павших во время междоусобной войны, которым военная власть отказывала в церковном погребении. На что Епархиальный совет постановил, что отпевания и поминания лишаются те, кто относился враждебно к церкви. ${ }^{8}$

Таким образом, взаимоотношения православного духовенства и советской власти развивались в режиме конфронтации друг с другом. Новая власть вела широкую антирелигиозную пропаганду среди местного населения и прежде всего она выражалась в периодической печати того времени. Священнослужители являлись главными контрреволюционерами большевистской власти, разорителями рабочих и крестьян, тунеядцами и лжецами, которые всяческими способами противостояли строительству нового государства. Православное духовенство акцентировало внимание над насилием, которым большевистская власть подвергала священнослужителей, а в период Гражданской войны активно поддерживала белогвардейские отряды.

\section{Список источников и литературы: Источники}

1. Слух об убийстве Еп. Амвросия // Воля Сибири. 1918. 10 октября. С.4.

2. Панихида // Воля Сибири. 1918. 2 ноября. С. 3.

3. Обращение Епископа Назария пастырям приходских советов и верующей пставе церкви енисейской // Воля Сибири. 1918. 31 декабря. С.3.

4. Митинг «Отца Петра» // Голос народа. 1918. 19(6) марта. С. 4

5. Во главе с попом // Деревенская коммуна. 1921. 15 января. С. 2.

6. Социализм и религия // Дело народа. 1918. 14 ноября. С. 6.

7. О крестных ходах // Деревенская правда.1918. 23 января. С.1.

8. Поп старается // Деревенская правда. 1918. 23 января. С.4.

9. Люди не от мира сего // Деревенская правда. 1918. 27 января. С.2.

10. Что показал крестный ход // Деревенская правда. 1918. 14 февраля. С. 2.

11. Нужны ли Богу мельницы // Деревенская правда. 1918. 14 февраля. С.4.

12. Крестины // Деревенская правда. 1921. 7 мая. С. 2.

\footnotetext{
${ }^{1}$ Енисейские епархиальные ведомости. 1919. № 5. С. 9.

${ }^{2}$ Деревенская правда.. 1918. 24 января. С. 4.

${ }^{3}$ Енисейские епархиальные ведомости 1919. №1-7 С. 12.

${ }^{4}$ Енисейские епархиальные ведомости 1919. № 3 С.7.

${ }^{5}$ Енисейские епархиальные ведомости 1919. № 3 С.8.

${ }^{6}$ Енисейские епархиальные ведомости 1919. № 4 С.27.

${ }^{7}$ Минусинский край. 1919. 5 апреля. С. 4.

${ }^{8}$ Енисейские епархиальные ведомости 1919. №4. С. 28.
} 
13. Православная церковь и Советская власть // Деревенская правда. 1921. 15 июня. С. 2.

14. Под церковью // Деревенская правда. 1921. 19 июля. С. 4.

15. Налог митрополита Вениамина // Деревенская правда. 1921.21 июля. С. 4.

16. Не в богах дело // Деревенская правда. 1921. 11 августа. С. С. 2.

17. Енисейские Епархиальные ведомости 1917. № 1 -9.

18. Енисейские Епархиальные ведомости 1918. № 2-18.

19. Енисейские Епархиальные ведомости 1919. № 1-10.

20. Поповская лавочка- хороший заработок // Красноярский рабочий. 1921. 17 февраля. С. 3.

21. Поповская разверстка // Красноярский рабочий. 1921. 17 февраля. С. 4.

22. Борьба с тунеядством // Красноярский рабочий. 1921. 18 февраля. С.1.

Литература.

1. Абросенко К. П. Религия на службе контрреволюции в Сибири. Иркутск: Иркутское обл. изд-во, 1938. $72 \mathrm{c}$.

2. Алленов А. Н. Власть и церковь в русской провинции в 1917-1927 гг.: На материалах Тамбовской губернии : Автореф. дис. канд. ист. наук. - Тамбов, 2004. - 24 с.

3. Буршин А. Ф. Вопрос отношения власти к религии в 1917 - 1920-х гг // Научный вестник Норильского индустриального института : научно-практический журнал. - 2009. -№ 5. -С. 56- 63.

4. Дворецкая А. П. Религиозная жизнь населения Приенисейского региона в первой трети XX в. (19001930-е гг.) . Красноярск : СФУ, 2015. -186 с.

5. Доброновская А. П. «И свет во тьме светит... !» Антицерковная политика 1917-1918 гг. Красноярская епархия // Православное слово Сибири. - 2003. - № 6. - С. 101-104.

6. Доброновская А. П. Русская Православная Церковь в Енисейском регионе в 1920-е гг. // Возрожденная Епархия: историко-публицистический и литературно-художественный альманах. - 2005. - № 1. - С. $43-47$.

7. Енисейские епархиальные ведомости. 1917. № 1-9. 56 с.

8. Лукин Н. М. Церковь и государство. - М.: Наука, 1922. -56 с.

9. Малашин Г.В. Красноярская (Енисейская) епархия РПЦ: 1861-2011 гг. Красноярск: Восточная Сибирь, 2011.-482 c.

10. Новикова Т.М. Взаимоотношения Русской православной Церкви и государства накануне Гражданской войны в Восточной Сибири: Автореф. дис. канд. ист. наук.- Иркутск, 2011. - 25 с.

11. Одинцов М.И. Государство и церковь: история взаимоотношений 1917- 1938 гг. М.: Знание, 1991. - 63 с. 12. Поспеловский Д. В. Русская православная церковь: испытания начала ХХ века. // Вопросы истории. 1993. - №1. - 398 c.

13. Соколов А. В. Временное правительство и Русская православная церковь. М.: ЭКСМО, 2002. - 154 с.

14. Снигирева Э.А. От февраля к октябрю (Церковь и политика). Ленинград: Изд-во Русский хронограф, 1973. $-180 \mathrm{c}$. 


\title{
КУЛЬТУРОЛОГИЯ
}

\section{АНАЛИЗ ПУТИ РАЗВИТИЯ ПУБЛИЧНОГО ОБРАЗА КИТАЙСКОГО УШУ С ТОЧКИ ЗРЕНИЯ «ACC»}

\author{
Cu Юŭ \\ Магистрант \\ Ланьчжоуский университет, \\ 2. Ланьчжоу
}

\begin{abstract}
Аннотация. В последние годы китайские научные исследователи проводили горячие обсуждения о проблеме “как развивать китайский ушу”, рассматривая прошлые результаты исследования, с точки зрения масс данная тема не придвалась широкой оглазке, что привело к появлению понятия “люди любят ушу, но не любят проекты ушу”. В связи с этим, обобщив и обработав литературные источники, интервью экспертов, сравнительный анализ и другие методы исследования, отталкиваясь от аспекта публичного имиджа ушу, были выдвинуты новые предложения и меры к развитию китайского ушу. Исследования показали, что в прецессе развития китайского ушу, нужно придавать особое внимание контролю широкого развития позволительной формы Ушу для общества, т.е. развивать внешне имеющийся своеобразный стиль атаки и обороны китайского боевого искусства, так же развивть несущую в себе китайскую традиционную гуманитарную концепцию о достоинствах, одновременно соответствующую современным научным принципам Ушу, такие меры поспособствуют стимулированию нормального развития китайского ушу.
\end{abstract}

Ключевые слова: развитие ушу; образ ушу; точка зрения масс

С ускорением процесса возрождения великой китайской нации, в последние годы китайское научное общество проводило горячие обсуждения на тему “как развивать китайский ушу”. В особенности после Олимпийских игр 2008-го года, ученые постепенно начали осознавают недостатки развития проекта Ушу, развитие ошибочного главного звена провела к такой неловкой ситуации, как «люди любят Ушу, но не любят проекты Ушу». Ряд мер, способствовавший становлению Ушу одним из видов состязания Олимпийских игр привело к отклонению восприяти обществом Ушу. Воображаемый людьми идеальный Ушу и Ушу в действительности образовали сравнительно большое расхождение. В последствии, создавшаяся разница идей повлияла на активность людей к деятельности Ушу, проект Ушу сталкнулся с проблемой снижения количества участвующих, снизилась активность участвующих и т.д. Однако, в отличие от Ущу, иностранные спортивные проекты, такие как, тхэквондо, каратэ, йога и т.д. стали предпочтительным выбором отдыха и развлечения людей, в частности развитие боевых искусств, например, тхэквондо, заняло место необходимости людей в китайском боевом искусстве, непрерывно подрывая пространство существования ушу.

До 2008-го года, китайские ученые единодушно пологали что ушу надо развивать по пути атлетического спорта. Для того чтобы вид китаского боевого искусства стал проектом олимписких игр, было проведено много теоретических и практических исследований. После Олимпийских игр 2008-го года, в то время, когда неудачная попытка внедрения Ушу в число проектов олимписких игр вновь побудила ученых анализировать причины неудачи, заключительной причиной установили разницу китайской и западной культур, так были выдвинуты новые высказывания как - «культурное самосознание, возвращение к трандиционной культуре» и т.д. Такое изменение из одной крайности в другую крайность, из-за дефицита разумного и объективного размышления, не способствовало практичному развитию Ушу. В основе былых теорий, некоторые ученые предлогали в основе наследования традиций усвоить достоинства западного профессионального спорта, принять тактику “заимствовать у других хорошее и восполнять свои пробелы, заимствовать западную тактику в китайском Ушу”. Несмотря на то, что такая теория помогла бы избежать недостадок бывших теорий, попытка использовать теорию “золотой середины” помогла бы достич лучшего результата, но как выбрать и определить эту “середину", что такое “середина", к этой проблеме нет конкретных мнений и инструкций. Но стоит отметить, что все вышеуказанные мылси заключаются в том, что их аспект отталкивается от “стандартной теории ушу”, т.е. в процессе исследования основы и цели развития Ушу, была упущена функция человека как создателя и пользователя Ушу. Не способность отталкиваться с точки зрения "человека", тем более не способность отталкиваться с точки зрения "масс", приводит к тому, что выдвинутое высказывание в большинстве течет поверхностно, есть верятность образования пропуска и недстатков, в определенном аспекте процесса работы нехватает действительной цели.

Победа и поражение всех культурных соперничеств в принце зависит от того, подходит ли перемена стандартов и нормы массовому психологическому требованию общества, а так же от того, принесет ли пользу стандарт их существованию и развитию. Спустя несколько десятилетий развития Ушу, только потому появились имеющиеся на данный момент вопросы, что в процессе перемены стандартов и нормы не было уделено должного внимания психологическим требованиям общества, а ударение больше делалось на 
регулировании, контролле и управлении государством, полагаясь на определенный этап руководства основных вопросов государственной политики. Все эти привело к тому, что фактически народный процесс развития ушу (традиционный) превратился в официальный (атлетический). Из-за недостатка народной поддержки, в длительном процессе развития неизбежно столкновение с препятствиями. Как утверджает Циао Сиаогуан: “Для того чтобы определить процветание или упадок одной культуры, нужно смотреть на количество носителей этой культуры». Развитие Ушу требует образованной общественной основой атмосферы, уважения и признания народных масс, не достаточно просто опираться на старания и настойчивость малочисленных учавствующих в состязаниях спортсменов.

Кроме этого, в нынешнее время в китае все так же имеется проблема неровномерного развития уровня способности практикующих и преподавателей. В области кинематографа, для того чтобы привлеч внимание публики и достижения более высокой коммерческой прибыли, в технике движений чрезмерно используют метод преувеличения. Все эти явления неготивно влияют на развитие и распростронение Ушу.

Согласно Марксизму, общественное сознание имеет динамическую реакцию на социальное существование, так что в обсуждении о развитии ушу надо учитывать общественное сознание массовых народ о развитии ушу, только тогда общественное сознание иммет доброкачественную и активную реакцию, когда развитие проекта ушу получить хороший результат. Таким образом, с аспектом понимания концепции массовых народ, создание плана развития ушу, развивание признанного народом ушу чрезвычайно необходимо.

Лу Синь сказал: “ Национальная культура-мировая культура.” Ушу, одна из трандиционных культурных форм, в процессе развития должен обращать внимание на сохрание свой собственный характер. Ушу отличается от дргих инностранных боевых исскуств том, что ушу формируется многообразное свойство, соответствующее общественным требованиям в разные общественные эпохи. Именно то многообразное свойство поставит основу для того, что китайский ушу стоит в лесу мировой культуры. Основным свойством ушу является бокс, цель которого - атака и защита. Однако это свойство не все свойства ушу, в процессе развития ушу принимает много ценных из китайской трандиционой культуры, например, китайской философии, исскуства, этики, религии, военных дел, китайской медицины и т.д. Словом, с точки зрения массовых народ, наличие китайской особенности и сути проекта противодействия, это настоящая категория ушу.

Что касается вопроса о том, как развивается ушу, то массы имеют наибольшее право голоса, так что обращание внимание на сознание народов к китайскому ушу, учет их мыслей, создавание самого научного пути, соответмтвующий требованию народов, это правилен. Это наиболее подходящий путь развития. Таким образом, с точки зрения общественности, современный настоящий китайский ушу - это формой с собственным уникальным стилем, содержение традиционных китайских гуманитарных ценностей и в соответствии с современным научным принципам. В прецессе развития китайского ушу, надо развивать признанную форму ушу, также включается в себя китайскую трандиционную гуманитарную концепцию о достоинствах, одновременно соответствует современным научным принципам, такие меры смогут стимулировать нормальное развитие китайского ушу. Только развивать такой ушу, то ушу станет популярным проектом спорта.

\section{Библиографический список:}

[1] Мань Вэнюй, Цию Писиан. Гормония: основная идея развития современного ушу / Мань Вэнюй, Цию Писиан // Вестник Шанхайского института физической культуры. - 2014. - № 38(02). - С. 48-51.

[2] Ван Ган, Ву Сун. С точки зрения “Великая концепция ушу” исследовние пути развития ушу / Ван Ган, Ву Сун // Вестник пекинского университета физической культуры. - 2013. - № 36(09). - С. 19-25+40.

[3] Ли Шоупэй, Гуо Юйчэн. Сравнительное исследование по уровню стандартизации степеней между китайским ушу, япоснским каратэ и южнокорейским тхэквондо / Ли Шоупэй, Гуо Юйчэн // Спортивная наука. - 2015. - № 35(08). - С. 86-91. 


\title{
МЕДИЦИНСКИЕ НАУКИ
}

\section{КРИТЕРИИ БЕЗОПАСНОГО ПРИМЕНЕНИЯ ДЕФОЛИАНТА ХЛОПЧАТНИКА «ФАНБАРАКА» В СЕЛЬСКОМ ХОЗЯЙСТВЕ}

\author{
Искандаров Тулкин Искандарович \\ доктор медицинских наук., \\ профессор, \\ академик Академии наук Республики Узбекистан, \\ заведующий \\ лаборатории Гигиены и токсикологии пестицидов \\ научно-исследовательского института санитарии гигиены и профессиональных заболеваний, \\ Республика Узбекистан, г.Ташкент \\ Романова Лилия Хабитуллаевна \\ кандидат медицинских наук., \\ стариий научный сотрудник лаборатории Гигиены и токсикологии пестицидов \\ научно-исследовательского института санитарии гигиены и профессиональных заболеваний, \\ Республика Узбекистан, г.Ташкент \\ Славинская Наталья Викторовна \\ кандидат медииинских наук., \\ старший научный сотрудник лаборатории Гигиены и токсикологии пестицидов \\ научно-исследовательского института санитарии гигиены и профессиональных заболеваний, \\ Республика Узбекистан, г.Ташкент \\ Искандарова Гулноза Тулкиновна \\ доктор медицинских наук., \\ профессор, заведующий кафедры Эпидемиологии \\ Ташкентского института усовешенствования врачей, \\ Республика Узбекистан, г.Ташкент
}

\section{CRITERIA FOR THE SAFE APPLICATION OF THE DEFOLIANT COTTON "FANBARAKA" IN} AGRICULTURE

Iskandarov T.I.,
Romanova L.Kh.,
Slavinskaya N.V.,
Iskandarova G.T.

Аннотация. В статье представлены данные экспериментальных исследований по обоснованию критериев безопасного применения дефолианта хлопчатника «Фанбарака» в сельском хозяйстве (с разработкой гигиенических нормативов в объектах окружающей среды: вода, почва, воздух и пищевые продукты; регламентов безопасного применения: санитарно-защитная зона (С33), сроки выхода на работу).

Abstract. The article presents experimental data on the justification of the criteria for the safe use of the defoliant of cotton "Fanbaraka" in agriculture (with the development of hygienic standards in environmental objects: water, soil, air and food; regulations for safe use: sanitary protection zone (SPZ), deadlines for work).

Права граждан Республики Узбекистан на благоприятную окружающую среду гарантируются Законом «О санитарно-эпидемиологическом благополучии населения» [1], в связи с чем, применение пестицидов в сельском хозяйстве разрешается после их тщательного токсиколого-гигиенического нормирования в объектах окружающей среды.

В настоящее время ведутся научные исследования по разработке физико-химических основ и технологии получения новых эффективных препаратов на основе соединений хлоратов, которые могут быть использованы для дефолиации, десикации и высушивания ботвы картофеля и других овощных культур, а также для ускорения созревания и увеличения урожая, в том числе хлопчатника. Вышесказанное определяет перед гигиенической наукой и практикой неотложную задачу своевременного проведения токсикологогигиенических исследований с целью гигиенической регламентации новых пестицидов в объектах окружающей среды, разработки мероприятий по её охране.

Исследования проведены согласно грантовому проекту ПЗ-2017091231 «Разработка токсикологогигиенических нормативов новых отечественных импортозаменяющих пестицидов в объектах окружающей среды и обоснование мероприятий по охране здоровья населения».

Цель исследований. Разработка регламентов безопасного применения нового дефолианта хлопчатника «Фанбарака». 
Материалы и методы исследований. Экспериментальные исследования проводились в соответствии c «Методологией комплексного и ускоренного нормирования пестицидов в объектах окружающей среды» [2]. В работе использовались токсикологические, гигиенические, биохимические и статистические методы исследований. Токсичность препарата определяли в соответствии с СанПиН № 0321-15 [3]. Изучался новый дефолиант хлопчатника «Фанбарака». Агрегатное состояние: жидкость, прозрачного цвета, с легким ароматическим запахом. Состав, \%: хлорат натрия - 36,0, карбамид - 20,0, фосфорная кислота - 0,8, аммиачная вода $-0,8$, этанол $-3,0$. Температура кристаллизации - не более $8^{0} \mathrm{C}$. При растворении в воде образует прозрачный раствор, устойчивый при общепринятых условиях хранения ядохимикатов. Процесс получения препарата осуществляется последовательным растворением карбамида фосфат карбамида, аммиака, этанола в растворе хлората натрия. Предложенная технология испытана на укрупненной лабораторной и опытной установке AO «Farg'onaazot» с выпуском опытной партии хлорат натриевого дефолианта и на его основе комплексно действующего дефолианта «Фанбарака» в количестве 150 кг. Препарат рекомендуется для применения в сельском хозяйстве республики в качестве дефолианта хлопчатника с нормой расхода 10 л/га, расход рабочего раствора - 3000 л/га.

Результаты исследований и их обсуждение. С целью установления средне-смертельной дозы препарата экспериментальные исследования проведены на белых крысах, мышах и кроликах. Животным внутрижелудочно вводили препарат в дозах 1000 - $2000-3000-4000-5000-6000-7000$ мг/кг. На протяжении всего периода наблюдения отмечались клинические признаки отравления в токсических дозах, характеризующиеся резким возбуждением животных после введения препарата, сменяющееся угнетением, кучкованием в углу клетки. Через 1 час после введения животные заторможены, часть животных принимала боковое положение, животные пофыркивали, наблюдалось прищуривание глаз. Через 4 часа с начала опыта у животных наблюдалось нарушение дыхания и гибель. У оставшихся животных имела место незначительная затормо-женность, при этом животные не отказывались от пищи и воды. Клиника интоксикации у всех видов животных была аналогичной. Таким образом, статистическая обработка полученных данных позволила установить средне-смертельную дозу препарата (ЛД 50 ): для белых крыс на уровне - 4250,0 мг/кг, ЛД $16-2375,0$ мг/кг, ЛД $84-6100,0$ мг/кг; для белых мышей на уровне - 4025,0 мг/кг, ЛД $16-3275,0$ мг/кг, ЛД $84-4750,0$ мг/кг; для кроликов на уровне - 4700 мг/кг. По результатам проведенного опыта можно сделать вывод о том, что препарат по параметрам острой токсичности относится к веществам IV класса опасности (малоопасное вещество, СанПиН № 0321-15).

Данные о токсичности препарата при внутрижелудочном пути поступления представлены в табл. 1.

\section{ТОКСИЧНОСТЬ «ФАНБАРАКА» ДЛЯ ТЕПЛОКРОВНЫХ ЖИВОТНЫХ ПРИ ОДНОКРАТНОМ ВВЕДЕНИИ В ЖЕЛУДОК (МГ/КГ)}

\begin{tabular}{|c|c|c|c|c|}
\hline № & Вид животного & ЛД $_{16}$ & ЛД$_{50}$ & ЛД $_{84}$ \\
\hline 1. & Белые крысы & 2375,0 & 4250,0 & 6100,0 \\
\hline 2. & Белые мыши & 3275,0 & 4025,0 & 4750,0 \\
\hline 3. & Кролики & - & 4700,0 & - \\
\hline
\end{tabular}

Местно-раздражающее действие препарата «Фанбарака». Экспериментальные исследования проводили на опытных животных - белых крысах. На выбритые участки кожи в области брюшка наносили препарат в нативном виде (жидкость). После 4-х часовой экспозиции препарат смывали проточной водой и проводили наблюдение за опытными участками. После введения препарата животные были беспокойными. После снятия аппликации на опытных участках отмечалась легкая гиперемия (розовый тон). Наблюдаемые признаки раздражения исчезали через 1 сутки с начала опыта. Вывод: препарат обладает слабым раздражающим действием на кожу.

Раздражающее действие препарата на слизистье оболочки глаз. Опыты по изучению раздражающего действия препарата на слизистые оболочки глаз проводили на белых крысах, в левый глаз которых вносили препарат в нативном виде, правый глаз служил контролем. После внесения препарата животные пытались почесать лапками опытный глаз. Через 1 час после внесения препарата - наблюдались некоторое сужение глазной щели, легкая гиперемия. Через 6 часов с начала опыта - выраженных признаков раздражения не отмечалось, глаз несколько прищурен. Через 1 сутки - явления раздражения отсутствовали. На основании выше изложенного, можно сделать заключение, что препарат обладает слабым раздражающим действием на слизистые оболочки глаз.

Кумулятивные свойства препарата. С целью оценки кумулятивных свойств препарата проведен «субхронический опыт» на 20 белых крысах. Животные были разбиты на 2 группы, вес животных 140 - 160 граммов, обоего пола. Первая группа получала препарат в дозе $1 / 10$ от ЛД контролем. В течение опыта гибели животных не отмечалось, что не позволило рассчитать коэффициент кумуляции. Однако по проявлению некоторых признаков интоксикации (незначительное угнетение, снижение приема пищи) и изменению биохимических показателей можно сделать вывод, что препарат обладает слабой функциональной кумуляцией. 
Хроническая токсичность. В результате изучения хронической токсичности препарата, установлены пороговая и максимально недействующая дозы препарата на уровне 7,5 и 1,5 мг/кг. На основании полученных данных рассчитана и научно обоснована допустимая суточная доза для человека - 1,8 мг/чел/сутки.

Нормирование препарата в объектах окружающей среды. ПДК (предельно-допустимая концентрация) в воде водоемов. Проблема охраны водоемов от загрязнения вследствие ее широкого народнохозяйственного и культурного значения и вызванные этим различия характера водопользования, сделало необходимой дифференциацию задач и методов научных исследований и практической деятельности применительно к интересам здравоохранения, сельского и других отраслей народного хозяйства. Экспериментальные исследования позволяют организовать и воспроизвести условия, выявить те концентрации, при которых вредное влияние того или иного химического вещества, еще не проявляется. Для обоснования ПДК пестицидов в воде водоемов предусматривается оценка признаков вредности вещества: санитарно - токсикологического и органолептического. Исследования по влиянию препарата на органолептические свойства воды имели целью определение пороговых концентраций препарата по влиянию на запах, привкус, цветность, прозрачность и пенообразование. Исследования проводились на основе зависимости «концентрация - эффект» с учетом только реакции человека. Для многих химических соединений именно органолептический признак вредности оказывается лимитирующим при обосновании ПДК. Для установления пороговой концентрации по влиянию препарата на органолептические свойства воды был применен массовый метод исследования, в котором участвовали одораторы. Исследования проводились с концентрациями препарата - 0,125 - 500,0 мг/л. Установлено, что препарат при попадании в воду придает ей специфический ароматический запах и привкус. Порог восприятия по запаху (1 балл) был на уровне 1,0 мг/л, практический порог (2 балла) на уровне 2,0 мг/л. Ввиду колебания пороговых величин, обусловленных индивидуальной особенностью одораторов, полученные результаты были обработаны статистическим методом Стьюдента-Фишера с учетом выскакивающих величин, с целью нахождения нижней доверительной границы, средне-арифметической величины и пороговой концентрации. Результаты статистической обработки позволяют считать порогом ощущения запаха концентрацию 1,03 мг/л, практическим пределом - 2,0 мг/л. С целью проверки точности и правильности проведения опытов был использован графический метод оценки органолептических данных, который позволил установить, что интенсивность запаха препарата увеличивается пропорционально логарифмам их концентраций, т.е. полученные данные соответствуют законам Вебера-Фехнера. При сравнении показателей интенсивности запаха препарата «Фанбарака» в воде по данным различных методов исследования можно сделать вывод, что они практически находятся на одном уровне, что говорит о достоверности проведенных исследований (табл. 2).

\section{ВЛИЯНИЕ ПРЕПАРАТА НА ОРГАНОЛЕПТИЧЕСКИЕ СВОЙСТВА ВОДЫ (ЗАПАХ) ПО ДАННЫМ БОЛЬШИНСТВА ОДОРАТОРОВ (1), РЕЗУЛЬТАТАМ ГРАФИЧЕСКОЙ (2) И СТАТИСТИЧЕСКОЙ ОБРАБОТКИ (3), «ЗАКРЫТОГО ОПЫТА» (4)}

\begin{tabular}{|c|c|c|c|c|}
\hline $\begin{array}{c}\text { Органолептический } \\
\text { показатель и его } \\
\text { интенсивность }\end{array}$ & $\mathbf{1}$ & $\mathbf{2}$ & $\mathbf{3}$ & $\mathbf{4}$ \\
\cline { 2 - 5 } & & & & \\
\hline Запах & 1,0 & 1,03 & 1,10 & 0,87 \\
\hline Порог ощущения & 2,0 & 2,0 & 2,29 & 1,74 \\
\hline Практический порог & &
\end{tabular}

Препарат в пороговой концентрации по влиянию на запах не изменял окраску воды, прозрачность, не вызывал пенообразования и не влиял на привкус. Таким образом, по влиянию на органолептические свойства воды лимитирующим признаком вредности является запах - пороговая концентрация 1,0 мг/л. С учетом проведенных исследований и данных санитарно-токсикологического эксперимента (пороговая концентрация 1,6 мг/л) рекомендуется ПДК препарата в воде водоемов на уровне 1,0 мг/л, лимитирующий признак вредности - органолептический (запах). ПДК в атмосферном воздухе и воздухе рабочей зоны. На основании общепринятых подходов к гигиеническому нормированию вредных веществ в воздухе, с учетом параметров токсичности и физико-химических свойств препарата, расчетным путем научно обоснованы и

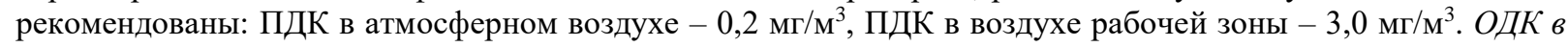
почве и МДУ в продуктах растительного происхождения. На основании методологии комплексного нормирования пестицидов в объектах окружающей среды и пищевых продуктах рекомендованы: ОДК (ориентировочно-допустимая концентрция) препарата в почве на уровне - 0,6 мг/кг; МДУ (максимальнодопустимый уровень) в хлопковом масле на уровне - «не допускается», в картофеле - 0,2 мг/кг.

Метод определения хлората натрия. Метод основан на восстановлении хлората натрия известным избыточным количеством двухвалентной соли железа и титровании избытка двухвалентной соли железа титрованным раствором бихромата калия в присутствии дифениламин-4-сульфоната бария в качестве индикатора (ГОСТ 29208.4-91). 
Метод определения карбамида. Определение буферной емкости карбамида выполняют потенциометрическим методом. Метод основан на измерении раствора соляной кислоты концентрации 0,05 моль/дм, необходимого для изменения значения $\mathrm{pH}$ раствора, содержащего 100 г карбамида в 1000 мл раствора, с 8 до 6 при температуре $20 \pm 0,5^{0}$ С. Потенциометрический метод определения (docs.cntd.ru/document/1200107404).

Натурные исследования по изучению гигиены применения препарата проводились на опытных участках Юкоричирчикского района Ташкентской области. Изучение условий труда механиков - водителей, выполняющих дефолиацию новым импортозаменяющим малотоксичным дефолиантом «Фанбарака» показало, что они подвергаются неблагоприятному воздействию запылённости, загазованности, низкосредне-высокочастотного шума, общей низко-средне-высотной вибрации, трудовой процесс носит напряжённый характер, что обусловлено длительностью сосредоточения внимания до 75\% рабочего времени и степенью ответственности за качество работы. По совокупности вредных производственных факторов условия труда механиков-водителей, производящих дефолиацию хлопчатника дефолиантом «Фанбарака» относятся к 3 классу 3 степени вредности, а уровень профессионального риска развития профессионально обусловленных заболеваний выше среднего.

При применении дефолианта хлопчатника «Фанбарака» в сельском хозяйстве необходимо руководствоваться разработанными гигиеническими нормативами и регламентами безопасного применения препарата (табл. 3).

ТАБЛИЦА 3

ГИГИЕНИЧЕСКИЕ НОРМАТИВЫ И РЕГЛАМЕНТЫ ПРИМЕНЕНИЯ

ДЕФОЛИАНТА «ФАНБАРАКА» В СЕЛЬСКОМ ХОЗЯЙСТВЕ

\begin{tabular}{|c|c|}
\hline Показатель & Величина \\
\hline $\begin{array}{c}\text { 1. ПДК в воде водоемов, мг/л } \\
\text { (лимитирующий признак вредности - } \\
\text { Органолептический - запах) }\end{array}$ & 1,0 \\
\hline 2. ПДК в атмосферном воздухе, мг $/ \mathrm{M}^{3}$ & 0,2 \\
\hline 3. ПДК в воздухе рабочей зоны, мг $/ \mathrm{M}^{3}$ & 3,0 \\
\hline $\begin{array}{c}\text { 4. МДУ: } \\
\text { в хлопковом масле, мг/кг } \\
\text { в картофеле }\end{array}$ & $\begin{array}{c}\text { «не допускается» } \\
0,2\end{array}$ \\
\hline 5. ОДК в почве, мг/кг & 0,6 \\
\hline 6. Санитарно-защитная зона (С33), м & 100 \\
\hline 7. Сроки выхода на работу, сутки & 5 \\
\hline
\end{tabular}

Заключение. Внедрение результатов исследований в практическое здравоохранение будет способствовать улучшению мониторинга за состоянием окружающей среды, снижению заболеваемости населения, повышению качества предупредительного и текущего санитарного надзора за объектами окружающей среды при применении нового дефолианта «Фанбарака».

\section{Литература:}

1. Закон Республики Узбекистан «О санитарно-эпидемиологическом благополучии населения». Ташкент, 2015. ст. 21.

2. «Методология комплексного и ускоренного нормирования пестицидов в объектах окружающей среды», Ташкент, 2014 г.

3. СанПиН РУз № 0321-15 «Гигиеническая классификация пестицидов по токсичности и опасности». 


\section{ПЕДАГОГИЧЕСКИЕ НАУКИ}

\section{ФОРМИРОВАНИЕ ПРЕДСТАВЛЕНИЙ О ВРЕМЕНАХ ГОДА У ДЕТЕЙ СТАРШЕГО ДОШКОЛЬНОГО ВОЗРАСТА}

Гребеникова Наталья Геннадьевна

стариий воспитатель,

МБОУ ичентр образования № 15 «Луч»

г. Белгорода

Проблема формирования представлений о временах года неразрывно связана с экологическим образованием ребенка. Дети старшего дошкольного возраста должны иметь в сознании четкие представления о временах года, понимание изменений в природе, знание названий месяцев, умение соотносить праздники со временем года и т.д. Сформированное представление о временах года и их особенности позволят ребенку устанавливать долгосрочные цели, приучает к дисциплине, и подготавливают к обучению в школе, где предусмотрены контрольные точки, каникулы и т.д. Поэтому для педагога основной задачей является создание благоприятных условий для решения задач по формированию представлений о смене времен года у дошкольников.

Затруднительность достижения цели обусловливается самой спецификой понятия «время», которое является абстрактным, т.е. его нельзя вернуть, ощутить, увидеть или потрогать. Также дошкольники затрудняются в понимании неконкретных словесных обозначений времени: «потом», «вечером», «после обеда». Следовательно, задачей педагога является подбор таких видов детской деятельности, которые бы обеспечили успешность усвоения понятия ритма часов и календаря, а также помогли научиться подстраивать под ход времени собственную деятельность, в том числе корректировать цели, устанавливать сроки, менять темпоритм действий.

Представления о временах года у старших дошкольников мы рассматриваем с точки зрения экологического образования детей. Данные представления по содержанию относим к экологическим представлениям, которые представляют собой сведения о взаимосвязи растений и животных со средой обитания, их приспособленности к ней; о человеке как части природы; об использовании природных богатств, загрязнении окружающей среды и так далее [1].

Анализ литературы по проблеме формирования представлений о природе у старших дошкольников показал, что в настоящее время нет конкретного определения «представления о временах года» Опираясь на определение «представления» и «экологические представления», мы сформулировали рабочее определение данного понятия. Представления о временах года - это чувственно-наглядные, обобщенные образы, отражающие сезонные изменения в живой и неживой природе.

Нами была организовано и проведено исследование уровня сформированности представлений о временах года у детей старшего дошкольного возраста, которое осуществлялось на базе муниципального бюджетного общеобразовательного учреждения центра образования № 15 «Луч». В исследовании принимали участие 20 детей подготовительной к школе группы № 3.

Организуя исследование уровня сформированности представлений о временах года у детей старшего дошкольного возраста, мы учитывали рекомендации С.Н. Николаевой [2]. Были предложены следующие диагностические методики:

Задание 1: «Лето». Цель: выявить уровень сформированности представлений о времени года «Лето».

Задание 2: «Осень». Цель: выявить уровень сформированности представлений о времени года «Осень».

Задание 3: «Зима». Цель: выявить уровень сформированности представлений о времени года «Зима».

Задание 4: «Весна». Цель: выявить уровень сформированности представлений о времени года «Весна».

Проанализировав полученные результаты исследования, пришли к выводу о том, что высокий уровень сформированности представлений о временах года отмечается у 15\% старших дошкольников, средний уровень характерен для 80\% детей и низкий уровень наблюдается у 5\% дошкольников (рисунок 2.1). 


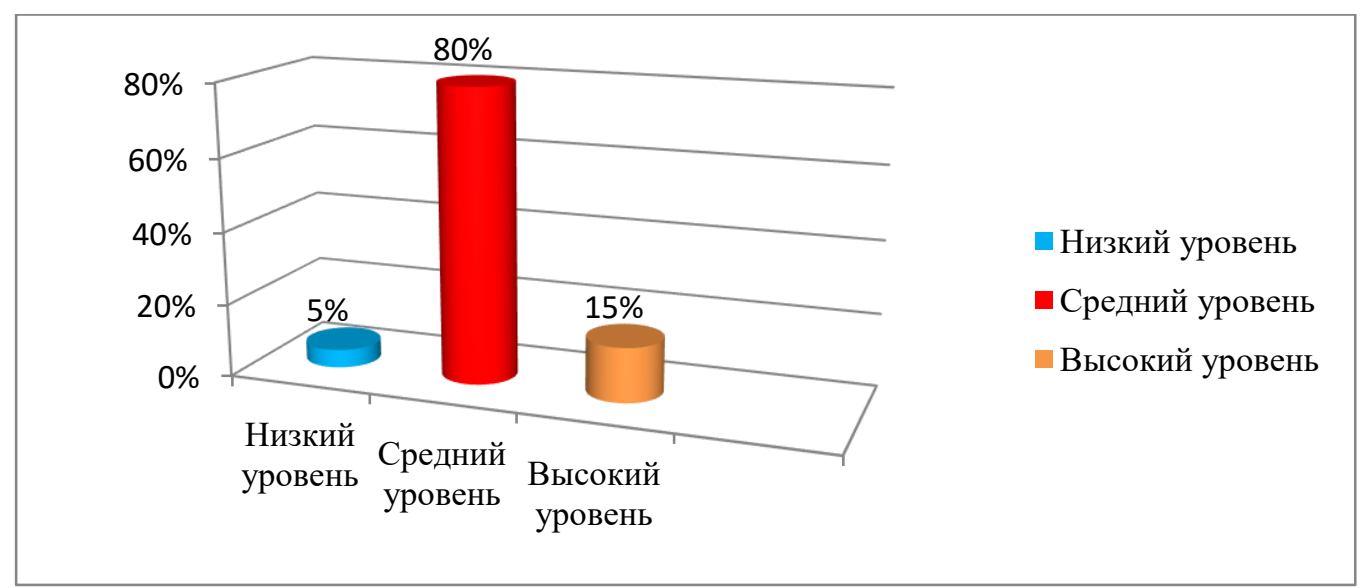

Рис. 2.1 Уровень сформированности представлений о временах года у старших дошкольников

В ходе выполнения диагностических заданий было выявлено, у детей с высоким уровнем сформированности представления о временах года носят системный, обобщенный характер. Дети без труда различают и называют времена года, месяцы каждого из времен года. Дошкольники знают изменения, происходящие с объектами живой и неживой природы, виды трудовой деятельности в разное время года. Устанавливают причинно-следственные связи между природными явлениями в определенное время года. Могут привести примеры.

Дети, показавшие средний уровень сформированности представлений о временах года, различают и называют времена года, знают названия месяцев, но некоторые испытывают затруднения с отнесением месяцев к конкретному времени года. Частично знают виды трудовой деятельности людей. С подсказкой устанавливают причинно-следственные связи между природными явлениями в определенное время года, некоторые дети затрудняются привести пример.

Дети с низким уровнем сформированности представлений о временах года имеют небольшие по объему, неточные представления о временах года. Они испытывали затруднения в различении времен года. С помощью подсказки называли признаки времен года. С помощью наводящих вопросов давали неполный ответ об изменениях, происходящих в живой и неживой природе. Частично знают названия месяцев, путаются в отнесении их к определенному времени года, не могут устанавливать причинно-следственные связи, приводить примеры.

Полученные данные указывают на недостаточную сформированность представлений о временах года у детей старшего дошкольного возраста, что обусловливает необходимость поиска путей решения данной проблемы.

Мы предлагаем следующие рекомендации по формированию представлений о временах года у детей старшего дошкольного возраста:

- использование методов моделирования и наблюдения;

- использование интерактивных методов и элементов технологии В.В. Воскобовича;

- реализация потенциала различных видов детской деятельности.

Рекомендация 1. «Использование методов моделирования и наблюдения»

Деятельность воспитателя по обучению моделированию осуществляется в следующей последовательности:

- воспитатель предлагает с помощью готовой модели, ранее усвоенной детьми, описать новые объекты природы;

- организует сравнение двух объектов между собой, с целью выделить признаки сравнения и сходства, одновременно отбирая модели, замещающие эти признаки;

увеличивает до 3-4 количество сравниваемых объектов;

- обучает моделированию существенных или значимых для деятельности признаков;

- руководит созданием моделей, таких как «птицы», «рыбы», «растения» и др.

Можно выделить такие этапы моделирования:

1 этап - овладение самой моделью: дети осваивают замещение реально существующих компонентов условными обозначениями, с целью расчленения целостного объекта или процесса на составляющие компоненты, абстрагирования каждого из них, установления связи функционирования.

2 этап - схематическая модель замещает предметно-схематическую, с целью подведения детей к обобщению знаний, представлений, формирования умения отвлечься от конкретного содержания и мысленно представить объект с его функциональными связями и зависимостями.

3 этап - использовать самостоятельно усвоенные модели и приемы работы с ними в собственной деятельности.

Одной из важнейших моделей при формировании представлений о временах года у детей старшего дошкольного возраста являются календари природы - графические модели, на которых отражены разнообразные, длительно происходящие явления природы. 
Выделяют три типа календарей, которые широко применяются в дошкольных учреждениях, они составляют содержание частых наблюдений и находятся в поле зрения детей. Календарь наблюдения за природой - отражает состояние неживой природы, растительного и животного мира в ту неделю, когда происходят ежедневные наблюдения. Календарь наблюдений за ростом и развитием растения или животного, в котором фиксируются изменения растущих растений и животных. Календарь наблюдения за птицами предполагает организацию зимней подкормки птиц.

На протяжении всего календарного года воспитатель должен проводить с детьми наблюдения за изменениями погоды. На протяжении всего календарного года воспитателю рекомендуется проводить с детьми наблюдения за изменениями погоды. Одним из способов привлечения внимания детей изменению температуры воздуха и наличию или отсутствию осадков проведение игры «Оденем куклу на прогулку», где дошкольникам перед прогулкой предлагается одеть куклу по погоде, объяснить, почему нужно использовать именно эту одежду. Другим способов понимания изменений температуры воздуха при наступлении холодного времени года - предложение детям на несколько минут снять варежки и почувствовать холод. В ходе наблюдений необходимо обращать внимание на силу и направление ветра, рекомендуется предложить детям найти солнце для понимания понятие «темнее» и «светлее». Воспитателю в ходе наблюдения следует делать акцент на звуках природы: завывание ветра, стук капель, пение птиц и др. Кроме этого, обращается внимание на деятельность взрослых, которая характерна для разных времен года. Наблюдения за объектами неживой природы, за объектами растительного мира происходит непосредственно в природе, в отличии от животного мира. При знакомстве с жизнью зверей необходимо использовать художественную литературу, картины и иллюстрации.

Наблюдения могут быть различными по тематике, по длительности: эпизодическими (полет снежинки) и длительными (за почками на деревьях) Рекомендуется проводить наблюдения на прогулках, экскурсиях, в процессе организованной образовательной деятельности, режимных моментах. Наблюдение может возникнуть спонтанно (на участок прилетела сорока). Важным аспектом является поддержание интереса детей к предмету или явлению. Целесообразно закрепить увиденное в рисунке или поделке.

Рекомендация 2. «Использование интерактивных методов и элементов технологии В.В. Воскобовича».

Целесообразно при формировании представлений о временах года у детей старшего дошкольного возраста использовать следующие интерактивные игры: «Микрофон», «Цепочка», «»Синтез мыслей», «Круг идей», «Общий проект», «Ассоциативный цветок», «Дерево решений», «Метод многоканальной деятельности», «За и против», «Показуха», «А что было бы, если бы...?», «Реклама» и др.

«Круг идей». Дети разделены на группы и каждая группа выполняет одно задание, например, составляют сказку по-новому или придумывают для нее другое окончание (закончи сказку «Снегурочка» иначе...)

«За и против». Детям предлагается решить проблему с двух сторон: за и против. Например, ставится задача рассказать, почему нравится зима (аргумент - «за») и почему не нравится зима (аргумент - «против»).

«Реклама». Дети делятся на команды, каждая из которых выбирает любой предмет (объект, явление природы) и пытается назвать все его положительные качества и функции, которые помогут привлечь к нему внимание других. Например, назвать все положительные функции дождя.

Интерактивное обучение в организованной образовательной деятельности происходит: в парах (2 ребенка), в микрогруппах (3-4 ребенка), в малых группах (5-6 детей) вместе с воспитателем. Интерактивные игры способствуют активному участию всех детей и развивают их творческий потенциал, любознательность, активность. Интерактивные игры эффективны при формировании представлений о временах года у старших дошкольников [3; 4].

Для решения задачи формирования представлений о временах года у старших дошкольников рекомендуется применять технологию $\quad$ В.В. Воскобовича, а именно возможности развивающей предметно-пространственной среды «Фиолетовый лес». Это сказочное пространство с играми и волшебными героями дает возможность формирования представлений о временах года у старших дошкольников. Помимо разработанных экологических сказок, автор технологии рекомендует педагогу самостоятельно составить сказку для детей исходя из программных задач. В.В. Воскобович предлагает следующий алгоритм создания сказки:

1.Постановка взрослой задачи.

2.Создание или выбор образа.

3.Оживление процесса.

4.Проблема.

5.Решение проблемы.

6.Проверка взрослой задачи.

Приведем пример использования технологии В.В. Воскобовича при формировании представлений детей о времени года «Зима»:

1.Проверить уровень сформированности представлений детей о времени года «Зима».

2.Выбор персонажа - Медвежонок Мишик.

3.Весной, когда начал таять снег и в лесу появились подснежники, проснулся медвежонок Мишик, выбрался из своей берлоги и тут же встретил друзей бельчонка и зайчонка, которые радовались окончанию зимы. «Зима? удивленно спросил Мишик. А что такое зима? Я ведь ее ни разу не видел»

4.Мишик не знает, что такое зима. 
5.Дети рассказывают Мишику, что такое зима, а именно называют ее характерные признаки.

6.В ходе рассказов детей о зиме, воспитатель делает вывод об уровне сформированности представлений о зиме.

Рекомендация 3. «Реализация потенциала различных видов детской деятельности»

Формирование представлений о временах года у старших дошкольников будет проходить успешнее при условии использования воспитателем потенциала различных видов детской деятельности.

Характеризуя игровую деятельность, отметим, что в течение дня целесообразно использовать дидактические игры, направленные на формирование представлений о временах года у дошкольников: «Что сначала, что потом», «Когда это бывает?» «Что изменилось?» «Четвёртый лишний» «Найди отличия». «Какое время года». «Что перепутал художник». Также можно использовать игры-путешествия: «Путешествие в осенний лес», «Что где растет», «Расскажи без слов», « путешествие в лес зимой, весной, летом, осенью. Кроме этого, рекомендуется включать интерактивные игры: «Что? Где? Когда?», «Показуха», «А что было бы, если бы...?».

Говоря о познавательно-исследовательской деятельности, отметим, что она включает рассматривание тематических картинок, подбор которых осуществляется для ознакомления детей с тем или иным временем года. На них изображены природные явления, деятельность детей и взрослых характерные для того или иного времени года. Чаще всего это изображение природных ландшафтов - пейзажи с различными временами года и связанными с ними видами деятельности. Воспитанники могут классифицировать картинки по сезонам, выявлять ошибки в работах художника, выстраивать изображения в правильном порядке и т.д.

Отмечая возможности трудовой деятельности, где конкретизируются представления детей о сезонном труде в природе. Например, осенью предлагается следующий ряд трудовых действий: уборка сухих листьев и веток; подметание дорожек; удаление сорной травы на огороде; уход за питомцами уголка природы и за растениями; уборка урожая свёклы, моркови, уборка участка от опавших листьев, подготовка огорода к будущим посевам; перекопка земли у кустарников, уборка участка от опавших листьев; изготовление кормушек для подкормки птиц зимой; развешивание кормушек для птиц, уборка участка от листьев, сухих веток деревьев.

Доброжелательный диалог и конструктивная беседа помогают развитию и формированию представлений о временах года у детей. Это отражает особенности коммуникативной деятельности. В разговор следует вовлечь как можно больше участников, стимулируя их активность вопросами: «Каково твое мнение?», «Что ты об этом думаешь?», «Все согласны с тем, что было сказано?». Рекомендуем следующие темы бесед: «Ранняя осень на земле», о живой и неживой природе, «Путешествие семечки», «Крылатые помощники», «Унылая пора! Очей очарованье!..», Итоговая беседа об осени, «Зимние приметы», «Почему зимой идет снег?» «Как животные приспособились к зиме», итоговая беседа о зиме (весне, осени, лете) и др. Кроме литературных источников полезно обращаться к творчеству педагогов и самих детей. Дети могут составлять рассказы о времени на разные темы: «Что было, есть и будет», «О зиме (весне, лете, осени)», «О любимых весенних (летних, осенних, зимних) праздниках».

Продуктивная деятельность реализуется в рисовании, лепке, аппликации, конструировании. Педагог предлагает детям проявить творчество и выразить в своих работах сюжет увиденного на прогулке или после прочтения художественного произведения. Для наиболее наглядного воплощения представлений детей о временах года педагогу необходимо подобрать наиболее лаконичные и конкретные темы для изобразительной деятельности. Например, «Золотая осень», «Зимнее небо», «Летние игры», «Зимние забавы», «Весенний лес» и др. Также рекомендуется предложить для рассматривания репродукции картин: «Утро в сосновом бору» И. Шишкина; «Утро» С. Чуйкова; «Последний луч» Н. Ромадина; «Зимний день в Седневе», «Лето», «Май», «Хлеб» Т. Яблонской; а также работы И. Левитана, Н. Рериха, Н. Ге и др.

Музыкальная деятельность: реализуется через проведение сезонных и календарных праздников: «Осенины», «Новый год» «День защитника отечества», «Масленица», «8 марта» и др., также через слушание программных произведений: Охота» («Сентябрь»), «Осенняя песнь» («Октябрь»), «На тройке» («Ноябрь») «Святки» («Декабрь»), «У камелька» («Январь»), «Масленица» («Февраль») «Песнь жаворонка» («Март») и т.Д.

Таким образом, качественное усвоение данных представлений позволяет старшим дошкольникам глубже проникнуть в смысл окружающей их действительности и способствует зарождению полноценной картины мира.

\section{Список литературы}

1.Николаева С.Н. Народная педагогика в экологическом воспитании дошкольников / Николаева С.Н. М.: Дошкольное воспитание, 2010. - С.94.

2.Николаева С.Н. Теория и методика экологического образования детей: Учеб. пособие для студ. высш. пед. учеб. / Николаева С.Н. - М.: Академия, 2012 - 336 с.

3.Руденко И.В. Современные образовательные технологии в работе с дошкольниками // Вектор науки Тольяттинского государственного университета, 2013. - № 2 (24). - С. 423-426.

4.Таланова М.А. Особенности организации образовательной деятельности дошкольников с использованием технологии интерактивного обучения «корзина идей»// Вестник Гуманитарного института ТГУ. - 2014. - №1 (15). - С. 25-27. 


\section{УДК 656.073 \\ ШКОЛЬНАЯ СРЕДА КАК УСЛОВИЕ АККУЛЬТУРАЦИИ ДЕТЕЙ-МИГРАНТОВ (ИНОФОНОВ) НА ПРИМЕРЕ ШКОЛЫ № 36 Г. ПЕРМИ.}

Колчанов А.Л.

директор МАОУ «СОШ №36»

2.Пермь

Интенсивные миграционные процессы на постсоветском пространстве, связанные с экономическими и политическими явлениями неминуемо затрагивают и образовательную сферу. Опыт многих стран мира показывает, что образование на сегодня является «одной из наиболее перспективных и развивающихся отраслей, приносящей многомиллионные доходы» (Тетерин В.И. Интернационализация высшего образования как способ коммуникации в современном образовательном пространстве (на примере пермских вузов). Проблемы современного педагогического образования. 2017. № 55-11. С. 234. ). Таким образом, рассмотрение проблемы мигрантов в образовании является крайне актуальным.

Рассматриваемое нами учебное заведение - это общеобразовательная национальная российская школа, т.е. образовательная организация, где реализуется российский национальный образовательный стандарт. Таким образом, на территории РФ (а также за ее пределами) все школы, где реализуется российский образовательный стандарт, являются «национальными российскими». Фактически все школы РФ с одной стороны - российские национальные (образовательный стандарт), а с другой - полиэтнические (до 15\% учащиеся разных национальностей). Российская общеобразовательная школа была полиэтнической всегда, поскольку на территории РФ насчитывается более 160 национальностей.

К настоящему времени название «полиэтническая школа» закрепилось за таким видом национальной российской школы, контингент которой до 15\% составляют «иноэтнические» учащиеся, владеющие русским языком на недостаточном уровне, чтобы он стал языком обучения в школе. Это дети мигрантов, которые поступают в обычную национальную российскую школу независимо от наличия гражданства и знания русского языка. Это порождает множество проблем, как для ребят, так и для педагогов данной образовательной организации, что выражено в предупреждении и сглаживании социально-языковой депривации, осуществлении диалога культур, создание среды профилирующего языка, воспитании толерантности и т.д.

Основным институтом социокультурной интеграции школьников в современную российскую полиэтническую среду является общеобразовательная школа. В начале XXI века заметно возрос интерес исследователей к феномену среды в связи с проблемами социализации детей и молодежи в нашей стране, а также исследованию культурных процессов в образовании в условиях ее новой образовательной парадигмы (Иванов А. В.Феномен культурной среды образовательной организации в освоении детьми духовных ценностей// Педагогическое образование в России. — 2016. — № 3.С. 200).

В качестве варианта такой общеобразовательной школьной среды предлагается к рассмотрению в данной статье модель, сложившаяся в школе № 36 г. Перми. Данная средняя школа находится в одном из отдаленных микрорайонов Перми, на окраине города. Это обычное общеобразовательное учреждение, и ей уже более шестидесяти лет. Школа находится в особой социокультурной среде городской окраины. Этнические мигранты оседают в данном микрорайоне в связи с близостью железнодорожной станции, складов и оптовых баз (требующих специфический и низкоквалифицированный труд), а также относительной дешевизною жилья. Эта часть города является примером поликультурной пограничной зоны, в которой сложился баланс между представителями различных социокультурных, конфессиональных и этнических групп населения. Данный микрорайон сформировался в результате эвакуации сюда во время Великой Отечественной войны переселенцев, что и предопределило принципы последующей межкультурной интеграции.

Педагогическим коллективом школы создается и нарабатывается с практикой ведения учебновоспитательного процесса, который претворяется в жизнь школы «поштучно» каждым учителем, через всеобщую и свою индивидуальную систему работы со школьниками: администрации, классных руководителей, родителей, учителей - предметников, психолога, логопеда и социального педагога.

Предметом внимания для школы и целью рассмотрения в настоящей статье авторами видится проблема: как наглядно и практически на материале показать - как и на основании чего именно у обучающихся, по мере обучения и становления их Личности в школе со временем происходит их адаптация и развитие в новой среде. Как происходит дальнейшее формирование школьника-инофона с самой начальной школы плоть до его выпускного экзамена в форме ЕГЭ. Как происходит это превращение его, «переплавление» в полноценно образованного, воспитанного и сформированного молодого гражданина РФ.

Зачастую будущего первоклассника в семье готовят и настраивают на предстоящую учебу в школе, как на интересную и захватывающую жизнь, на новых друзей, на саму встречу со школой и с Учителем. Все это нормально и обычно «упаковывается» как праздник, ведь, прежде всего для будущего первоклассника это вступление в более сложную, более «взрослую» для него жизнь. Атмосфера предпраздничной подготовки к школе и самого праздника, радостных открытий нового и обучающих игр рано или поздно завершается, и 
наступают трудовые будни, а учиться ребенку, узнавать много нового - это и интересно и оказывается порой совсем нелегко (т.к. «Без труда, не вынешь рыбку из пруда»- результаты требуют усилий). Этот вариант ожидаемого стресса в каждой российской семье переживается по-своему, однако рано или поздно такая адаптация приходит.

Говоря же о ребятах, приходящих в данную школу из совершенно иной языковой среды и культуры, зачастую вообще без знания русского языка, при этом члены семьи не способны оказать эффективной помощи, т.к. родители дома предпочитают общаться с ребенком и между собой на их родном языке. Данная категория детей пополняет учебные классы рассматриваемого нами образовательного заведения ежегодно, что, также безусловно, формирует стрессовую ситуацию. Такие дети, приходя в школу, испытывают настоящий «культурный шок».

Формирование у ребенка двух языков одновременно - сложный процесс, требующий определенных усилий, терпения, поддержки и внимания родителей, однако при этом и вопреки многим стереотипам, не требует привлечения узких специалистов. Результаты такого положения для подобных ребят часто получаются «на выходе», по окончанию школы, очень интересными: хотя и с запозданием данная категория детей делает качественный скачок в развитии. Они меньше других болеют, сравнительно более гибки, психологически пластичны - не все ребята и далеко не стопроцентно разумеется, но как следствие, они чуть более успешны в общении.

Реальное процентное соотношение таких ребят для исследуемой школы за последние пять лет было следующим: в 2014-2015 учебных годах при общем количестве 620 учащихся - 7,5\% инофонов, в 2015-2016 у/гг.,при 694 учащихся - 7,3\%, в 2016-2017 у/гг., при 767 учащихся - 6,3\% и в 2017-2018 у/гг. на декабрь месяц,при 780 учащихся - 7,2\%. Это все дети-школьники, для которых русский язык не является родным. Большая их часть, т.е. более $50 \%$, совсем не владела русским по приходу в начальную школу, кроме того, всегда есть учащиеся и в среднем звене, которые приходят в данную школу в разное время. Эти ребята бывают разных возрастов, адаптация у них тоже - разная.

Предмет нашего внимания - такие ребята, потому что выходит, что вынужденный изначально стресс представляется нам в дальнейшем как существенная ступень и возможности для развития дополнительного потенциала у инофонов (весь период становления личности от ребенка до молодого человека) на базе средней общеобразовательной школы. Русский язык для них выступает в двух ипостасях - как проблема, и русский язык - как спасение и уже в последствии достойный выход из положения.

В образовательном заведении предпринимаются целенаправленные шаги и попытки значительно развивать и усиливать деятельность по изучению русского языка во всех возрастных группах. Русский язык - это способ мышления для них, развития и обнаружения новых ракурсов осознания действительности, способ точнее понять окружающих и вырабатывать в себе такие нюансы понимания человеческой природы, которые никогда не могут быть формализованы.

Ребенок в процессе социализации переживает все этапы эволюции мышления общества, а социальная группа вырабатывает внутри себя свой особый тип и стиль мышления. Язык в этом смысле - это не просто средство коммуникации, но и инструмент проникновения в особую культурную среду, и восприятие способа мышления, характерного для нее. Для ребенка, изначально находившегося в одной культурной среде, а затем попавшего в другую, этот процесс приобретает черты вариативности. Это закаляет ребенка в стрессовой ситуации, заставляет раскрывать потенциал его интеллекта с повышенной эффективностью, а его мышление приобретает гибкость.

В данном контексте представляет интерес сохранение русского языка и культуры эмигрантами первой волны (часто именуемые белоэмигрантами). Широко известно об иммигрантах в странах Запада (Франция, США, Австралия и др.). Однако, даже на дальневосточном участке, в Китае русская эмиграция посредством сохранения языка и культуры сохранилась как минимум до конца Второй мировой войны. Кроме того, она стала одним из центров притяжения для других этнических групп эмигрировавших с территории Российской империи. По данным Е.В. Яковкина: «Национальный состав был представлен в основном русскими, также присутствовали украинская, белорусская, грузинская, бурятская, татарская и другие национальные общины». (Яковкин Е.В. Русские солдаты Квантунской армии / Е.В. Яковкин. - М.: Вече, 2014. С. 10-11)

Именно у инофонов, обладающих своим языком, а значит и мышлением от иной культуры, появляется уникальное преимущество в актуализации себя и своей личности в другой культуре. Это осознавание и реализация себя при посредничестве между различными этносоциальными группами. С другой стороны, это индивидуально и может создавать для ребенка, только начинающего свой жизненный путь, и определенные проблемы самоидентификации себя и своего места в мире.

«... Пример с не более чем 7,5\% инофонов, составляющих контингент учащихся общеобразовательного учреждения, доказывает, что именно разумный и определенный баланс принятия детей с иным культурным и языковым кодом в новую для них среду оказывается эффективным, не позволяя образовывать некие культурные анклавы ведущие социум к деструктивной спорадизации, но в то же время, давая возможность к их лучшей,... адаптации в контексте «поиска себя», и их максимально эффективной интеграции. (см., например, Калашникова, Е.М. Личность и общество (Проблема идентификации): монография. - Пермь: издво Пермск.гос.ун-та, 1997.-156 с.) 
Младшая (начальная) школа - создаются первичные ЗУНы, т.е. посредством игры и различных форм деятельности, дифференциации, ребятами осваиваются навыки существования среди сверстников и умения учиться. Взаимодействие школы с ним и его семьей и создание вариантов детско-взрослой общности в микро коллективах классов. Учитель - это тот, кто много делает для детей, и зачастую меньше всего при этом он думает, что же он будет иметь от ученика. Главное тут, что он делится не просто знаниями, а миропониманием, и это очень дорогого стоит! В рамках формируемой образовательной среды необходимо целенаправленно восстанавливать приоритет человеческого общения, что представляет собой и известные сложности в мире, у всех и повсюду (цифровое общение, и кликовое или клиповое) мышление глобальных масштабов.

Средняя школа (подростковый возраст) - это тот период, когда помимо основных учебных задач, у ребят активно происходит социализация во внешнем мире, поиск своего места в разных социумах, умение вести диалог, общаться, сотрудничать и развивать свои навыки самовыражения как личности. Требования для всех одни: обучение ведется по одним учебникам и программам, нет дифференцированных заданий для контрольных работ, но при этом учителю приходится решать проблему выравнивания.

В основе работы с учащимися среднего звена лежат индивидуальный и дифференцированный подходы, периодически и на всех этапах урока и, конечно, внеурочная работа. При сложившейся ситуации, оставаясь один на один с обозначенными проблемами, учитель-словесник вынужден в рамках программы максимально использовать имеющийся методический материал. Он постоянно находится в поиске эффективных средств воздействия, форм работы и выработке разнообразных принципов организации учебной деятельности для таких классов.

Старшая школа (младший юношеский возраст) - обучающиеся осознанно учатся искать и выбирать профили и индивидуальные траектории собственного развития, готовятся к итоговым экзаменам. Специализируются через пробы и практики («понять, что не мое - точно»), они проходят программы профессиональной подготовки, пытаются искать и определять себя в сфере будущей деятельности. Ведь образование в самом широком нашем понимании - это не про то, чтобы «впихнуть» в себя какие-то знания и кому-то что-то там сдавать... Образование для молодого человека - это про то, как найти свое место в мире, делать для него что-то полезное, поменьше конфликтовать по жизни или переживать, а больше радоваться. А вот как раз для этого то и надо что-то понимать про этот самый мир, и в какую сторону и как он меняется.

Педагогический коллектив в школе должен создавать воспитывающие условия для обучения и благоприятную обстановку для развития общей культуры каждого ребенка, навыкам работы с потоками информации, культуры мышления. Нам надо не столько вести ученика «за руку», сколько показывать ему что и как лучше было сделать, поддерживать, сопереживать, помогать искать индивидуальные пути и варианты решений, тем самым в этом процессе познавать себя. Ключевыми моментами здесь и направлениями является фигура Учителя, традиции и наработки в повседневных буднях деятельности школы, а также вся атмосфера выстраиваемых взаимоотношений.

А. Эйнштейн сказал: «Целью работы школы должно быть воспитание гармоничной, развитой личности, а не специалиста...». В школе мы не просто учим своих учеников, а прежде всего - создаем им условия, в которых они сами учатся. Предпринимается попытка создавать среду и общую культурологическую направленность нашего учебно-воспитательного процесса - на самом деле нам надо в молодом человеке зародить то, что будет двигать его вперед, а знания он будет получать параллельно с вхождением в жизнь.

Главным результатом школьного образования для нас является его соответствие целям опережающего развития молодых людей. Наши школьники должны сейчас изучать не только факты истории, итоги и мировые достижения сегодняшнего дня или прошлого развития человечества. Они должны готовиться и быть способными к вызовам и методологии решений задач, которые хотя и неясны нам еще сегодня, но завтра они «встанут» перед ними уже всерьез, и им предстоит решать их самостоятельно и ответственно. Мир вокруг нас меняется слишком динамично и качественно, а это обязывает нас учитывать действительность и действовать на опережение, и такая готовность выпускников необходима обществу будет уже в самом ближайшем и обозримом будущем.

Ключевой особенностью современного школьного образования становится внедрение модели, предполагающей высокую гибкость, релятивность аналитического аппарата. Подрастающее поколение должно научиться реагировать на постоянно меняющиеся условия, обновляющуюся информацию, встраивая ее в уже имеющийся у него систему ценностей и ориентиров. В противном случае человек оказывается ведомым, его личное мнение и оценка теряется под массой различного рода клише, стереотипов, культивируемых средой, он теряет возможность к конструктивной рефлексии. При этом каждому человеку приходится проходить свой путь взросления самостоятельно, что актуально и для начальной, и для средней школы и для ее старшего звена. Сталкиваясь с насущными учебными и бытовыми проблемами, личность незаметно для себя приобретает те или иные особенности и индивидуальные черты.

Если человек изначально находится в условиях, при которых его социальное благополучие зависит от умения выстраивать коммуникации, а информационное общество предполагает именно такую модель. При этом логично предположить, что имеющая подобный навык личность окажется более успешной и будет обладать высокой конкурентоспособностью, способностью решать не тривиальные задачи. 
В процессе социализации в постоянно изменяющемся мире такой личности необходима современная школа, та которая бы позволяла наиболее полно раскрыть потенциал такой личности. Таким образом, перед современной школой стоит, помимо бумаготворчества, изматывающей и огорчающей педагогов текущей работы, крайне важная и сложная задача - определять, что именно и почему будет востребовано обществом в недалеком «завтра», а самое главное - претворять это в жизнь, т.е. обеспечить формирование направленности и реализацию, таких аспектов общественной деятельности как:

«Цифровизация» всех сфер нашей жизни

Роботизация, т.е. автоматизация в быту, промышленности и экономике

Глобализация знаний, экономики и технологий. Мы сейчас учимся мыслить на уровне целого мира, планетарно, но при этом рискуем, а то и теряем самобытность, культуру...

Экологическое мышление, где каждый в этом мире видит себя частью экосистемы и чего-то большего, где человек, так или иначе, влияет на всю экосистему нашей планеты в целом

Демография, меняющиеся рынки труда и умение учиться или переучиваться всю жизнь

Сетевое мировое сообщество, где все связано в единую сеть и очень многое становится все более гибким, упрощенным (бюрократия) и самоорганизующимся.

Социально-технологическое ускорение развития в мире, где отдельно взятый человек уже физически не может успевать за объемами информации и осознанием всех изменений, учится оценивать риски: ««рискориентированное мышление» - это способность индивида определять ситуацию с позиции риска, идентифицировать, анализировать и оценивать риск, обладание готовностью воздействовать на риск с целью получения положительного результата, включающего безопасность жизнедеятельности» (Dolina I.G., Kushnaryova O.V. Forming occupational safety culture on the basis of development of student's risk-focused intellection//International journal of environmental and science educationДля изучения ситуации сложившейся в конкретном образовательном заведении - школы № 36 г. Перми. Нами была проведена опытнопрактическая работа. Во многом актуальные результаты проводимого нами исследования отражают и современные социальные потребности (Приложение 1)

На их основе мы можем увидеть, что является универсальными примерами, а что характерно только для конкретной школы.

Наш Президент говорит: «На русском языке мы думаем, излагаем свои мироощущения, общаемся и воспринимаем всю информацию. А ведь мудрая, взвешенная и осмысленная языковая политика - едва ли не самое сложное, деликатное и важное условие сохранения целостности многонационального государства, общества и единства всего народа, передачи от поколения к поколению устоев, традиций и ценностей.... Все богатство русского языка, его неисчерпаемые возможности - это золотой запас, который необходимо ценить и всемерно оберегать. Чем выше уровень знаний и использования языка в обществе, чем выше культура речи, тем мощнее интеллектуальный уровень нации, потенциал ее развития. У конкретной личности примитивный язык почти всегда отражает примитивное мышление. И, наоборот, владение образной, яркой, литературной и грамотной речью резко увеличивает конкурентное преимущество человека, высоту его положения на социальной лестнице, да и просто определяет его общую культуру...» (из выступления В.В.Путина на объединенном Совете по русскому языку в Москве 19.05.2015 г.// http://kremlin.ru/events/president/news/49491).

Русский - государственный язык нашей страны, язык межнационального общения. Именно он, русский язык, по сути, вместе с культурой сформировал Россию как единую и многонациональную цивилизацию, на протяжении веков он обеспечивал связь поколений, преемственность и взаимообогащение этнических культур. Мы осознаем, что все информационное, культурное и государственное единство страны, единение всего российского народа напрямую зависит от освоения нашими молодыми людьми общенационального языка, от состояния и распространения русского языка.

Русский язык в нашей проблеме - это ключевое звено и основа создания в школе для детей среды общения и их погружения (вхождение в культуру этноса: участие в сценках на праздниках, скороговорки, расшифровка для них смысловых связей, а это обычно актуально) - как основа их адаптации в школьной среде.

У детей-инофонов есть особенность: они воспринимают закономерности русского языка через призму своего языка, и они переносят явления родного языка на русский язык, что часто ведет к ошибкам. Первая задача учителя здесь - преодолевать влияние родного языка, предупреждать интерференционные ошибки в русской речи. Для некоторых ребят характерным поведением является стремление обособиться и замкнуться в себе, ограничить свой круг общения исключительно по национальному признаку, опираться на обычаи, традиции и нравственно-этические нормы своего этноса (Суханова Е. Технологии и методические приемы обучения русскому языку в полиэтнических класcax// https://xn--j1ahfl.xn-p1ai/library/\%C2\%ABtehnologii_i_metodicheskie_priemi_obucheniya_russkom_163757.html).

С точки зрения Й.Хейзинга - мы изначально, на самых ранних этапах своей социализации, учимся примерять на себя те или иные роли, устанавливая правила, стремящиеся идеализировать все возможные ситуации социальных отношений, со временем этот идеальный образ мы стремимся расширить и воплотить в жизнь. «Внутри игрового пространства господствует присущий только ему совершенный порядок положительное свойство игры: она устанавливает порядок, она сама есть порядок. В этом несовершенном 
мире, в этой сумятице жизни она воплощает временное, ограниченное совершенство» (Хейзинга, Й. Ното Ludens. Статьи по истории культуры. - М.: Прогресс - Традиция, 1997. - 416 с, с.39). «Игра в общение» создаёт иллюзию того, что мы превращаемся в кого-то другого, который в случае кризисной ситуации будет страдать, принимать на себя ответственность за неуспех в выполнении поставленной задачи: «Переодевшийся или надевший маску «играет» иное существо. Но он и «есть» это иное существо» (Хейзинга, Й. Homo Ludens. Статьи по истории культуры. - М.: Прогресс - Традиция, 1997. - 416 с, с.43).

Ребенок-инофон в процессе проникновения в особенности русского языка изначально воспринимает все происходящее именно как игру, этому способствуют и игровые формы работы с ним. В дальнейшем этот навык подсознательно экстраполируется им на остальную деятельность. Он оказывается более готов и адаптивен к меняющимся «правилам игры», чем тот, кто изначально был погружен в её атмосферу и поэтапно осваивал ее правила. Тот факт, что инофоны совместно осваивают неродной для них язык, приобщаясь к новой для них культуре, многие из особенностей которой им не ясны, создаёт синергетический эффект. Каждый из них привносит свое видение нового культурного кода, пропуская его через себя (ведь только так можно понять и осмыслить новое), тем самым обмениваясь вновь увиденным и услышанным с другими инофонами, также замотивированными на освоение нового языка, и создавая общую картину реальности. Последняя оказывается более сложной и комплексной, чем каждая из индивидуальных картин, создаваемых сознанием отдельного ребенка. Подобная культурная интерпретация - восприятие норм и обычаев нового этноса через призму предшествующего культурного основания в дальнейшей жизни может быть перенесена на любое новое получаемое знание.

Мастерство учителя-словесника, участие которого становится необходимым на определённом этапе, в этом случае заключается не просто в постановке речи и правильности произнесения звуков, но в налаживании связи между звуком и интерпретацией смыслов, всвоего рода, герменевтическом акте, раскрывающем новый горизонт мышления юного инофона. Горизонт мышления оказывается значительно расширен за счет четко расставленных ментальных акцентуаций - то есть каждый ключевой для понимания новой среды смысл должен быть помещен строго в отведённое для него место, оставляя, однако, возможность, для более глубокого его осмысления или даже замены в процессе дальнейшего освоения новой культуры по мере взросления инофона. Взаимодействие с носителями языка для него становится одновременно и критерием истинности полученного знания и способом менее формального проникновения в его особенности. Последнее предполагает и наличие более сложной рефлексии, в которую оказывается включен не только конкретный представитель иной языковой среды, но и внешний наблюдатель - учитель, другой инофон, помогающий взглянуть на собственную интерпретацию событий не только изнутри, но и из вне, понять на уровне спонтанного, но в тоже время, многоступенчатого рефлексивного анализа ситуации как именно осуществляется мыслительный акт и каковы его результаты.

Таким образом, для первого этапа адаптации для таких детей, помимо простого погружения в среду, является обучение русскому языку, освоение и изучение живой русской речи для их успешной социализации и последующего освоения всех дисциплин. Период относительного или полного освоения русского языкобычно индивидуален, но он варьируется от 4-х до 12 месяцев ? и это справедливо лишь для ребят в 7 - 9 лет, во всех иных случаях степень разброса увеличивается и трудно поддается систематическому анализу.

Задача учителя, работающего с инофоном, заключается не только и не столько в заучивании языковых форм, речевых оборотов или лингвистических конструкций, а в том, чтобы ввести в ментальную матрицу социализирующегося субъекта навыки аналитической рефлексии, давать возможность ребенку иной языковой среды научиться реализовывать свое преимущество.

Основной задачей преподавания русского языка как иностранного, является создание многоплановой языковой среды. Просто урока здесь явно недостаточно, это и предупреждение ошибок в точности высказываний и в речи, вовлечение в игровую атмосферу и деятельность, разъяснение смысла подтекстов или метафор и само академическое овладение основными нормами русского языка, как приоритета для поликультурного образования.

Своевременная и корректная работа учителя по обучению русскому языку инофонов затрудняется разными причинами. Основная из них - неоднородность владения русским языком среди самих детейинофонов, обучающихся при этом в одном и том же классе. Так же это справедливо и среди детей, для которых русский язык является родным, особенно это касается академически слабых классов или конкретных отстающих ребят.

Учитель, обучающий детей с трудностями освоения русского языка, как правило, имеет стандартное педагогическое образование, предусматривающее преподавание русского языка ? направленное на носителей языка. Поэтому перед учителем стоит непростая задача разрабатывать как для инофонов, так и для остальных детей, индивидуальную стратегию педагогического воздействия. Игровые коллективные формы учебной деятельности, работа детей в парах, с карточками, работа по цепочке и индивидуальная работа.

Здесь наработаны и учитываются: создание индивидуальных карточек на каждого ребенка, поддержка его или отсутствие помощи со стороны родителей, логопедические вопросы, их сложность, психологические особенности, динамика поведения и результаты деятельности, мотивация, способности, 
эмоциональная и общая активность каждого из детей. Работа логопеда почти всегда необходима с такими детьми, т.к. логопедические вопросы практически напрямую влияют на успешность занятий, но - по мере их сглаживания - наступает постепенный прорыв в учебе, дети заметно лучше начинают учиться.

Инофон в процессе проникновения в особенности русского языка изначально воспринимает все именно как игру, этому, помимо возраста способствуют и игровые формы работы с ним. Этот навык потом подсознательно экстраполируется им на остальную деятельность. Он оказывается более адаптивен к меняющимся «правилам игры», чем тот, кто изначально был погружен в ее атмосферу и поэтапно осваивал ее правила.

Инофоны совместно осваивают неродной для них язык, приобщаются к новой культуре, многие из особенностей которой им не ясны, тем самым создают синергетический эффект. Каждый из них привносит свое видение нового культурного кода, пропуская его через себя (ведь только так можно осмыслить все новое), обмениваясь вновь увиденным и услышанным с другими инофонами, также замотивированными на освоение нового языка, и создавая свою картину реальности. Последняя оказывается более сложной и многослойной, чем каждая из индивидуальных картин, создаваемых сознанием отдельного ребенка. Подобная культурная интерпретация - восприятие норм и обычаев нового этноса через призму предшествующего культурного основания в дальнейшей жизни может быть перенесена ребенком на любое новое знание.

Профессионализм логопеда, участие которого становится необходимым на определенном этапе, заключается не просто в постановке речи и правильности произнесения звуков, но в налаживании связи между звуком и интерпретацией смыслов, в особом акте, раскрывающем новые границы мышления юного инофона. Горизонт мышления значительно расширяется за счет четко расставленных ментальных акцентуаций - каждый ключевой для понимания новой среды смысл должен быть помещен строго в отведенное для него место, оставляя, при этом, возможность для более глубокого его осмысления или даже замены в процессе дальнейшего осмысления новой культуры по мере взросления инофона. Взаимодействие с носителями языка для него становится одновременно и критерием истинности полученного знания и способом менее формального проникновения в его особенности.

Вопрос повышенной способности к рефлексии, как выработанного с детства умения отдавать отчет всем своим поступкам, анализировать свои мысли и конкретные шаги можно считать ключевым конкурентным преимуществом представителя иной языковой среды - инофона.

Поскольку дети, изначально находящиеся в родной для них культурной среде, не испытывали нужды в осмыслении того, что они говорят или делают на таком уровне, какой требуется от инофона, зачастую действуя спонтанно, их способность к конструктивному самоанализу, в этом смысле, оказывается априори ниже.

По мнению Сыкалова И.А.: «...в большей степени культурологию интересуют духовные ценности, основополагающие нормы» (Сыкалов И.А. Социология права в контексте эмпирических исследований права: ПРОБЛЕМЫ СТАНОВЛЕНИЯ, ПОЗИЦИОНИРОВАНИЯ И ИНСТИТУЦИОНАЛИЗАЦИИ. Пенитенциарная система и общество: опыт взаимодействия сборник материалов VI Международной научно-практической конференции. Пермь, 2019. С. 180.). По этой причине обучение ребенка-инофона становится объектом не только педагогического, но и культурологического воздействия и анализа. В этом отношении культурология имеет прямое отношение к изучению ценностно-рационального поведения.

Ребенок из иной культуры вынуждено пропускает через себя поток новой информации. Проникаясь ею на всех уровнях восприятия - эмоциональном и волевом, на уровне конкретного и абстрактного мышлений, ученик получает и развивает этот навык в большей степени. Это значит, что он учится лучше понимать жизнь, меньше расстраиваться по мелочам или из-за неудач и труднее позволяет втягивать себя во всевозможные конфликты. Это своего рода «прививка здравого смысла», она и создает ему качество жизни как представителю иной языковой среды.

В качестве способа практического обоснования нами была разработана Анкета (Приложение 1).

Анкетирование проводилось среди учащихся начальной и средней школы в возрасте от 7 до 16 лет. Участникам была предоставлена возможность сохранения анонимности.

В целом, было опрошено более 300 человек из них, 75 человек представлены инофонами.

Национальности: армяне, азербайджанцы, киргизы, таджики и др. представители народов ближнего зарубежья.

В процессе обучения в школе полностью овладели языком - 95 \%

Овладели языком не в полном объеме - $5 \%$

Социализация обучающихся инофонов за период обучения составляет 100 \%:

1) Из пришедших на начало обучения в школе с нулевым уровнем владения русским языком - $68 \%$

2) Полностью овладели русским в дошкольных учреждениях - $25 \%$

3) Билингвы (владеющие языком своей этнической группы и русским языком) - 7 \%

В целом, обучающиеся трезво оценивают свое знание языка. Многие дети откровенно заявляют о своей неграмотности. А некоторые из них желают устранить данный недостаток.

В процессе анкетирования мы встретились со следующими высказываниями в отношении русского языка: 
«Горжусь своим языком» (носитель русского языка)

«Считаю, что русский язык может стать интернациональным»

«Хорошо, но русский уже перемешался с английском это не хорошо» (носитель русского языка)

«Я хотел бы, чтобы русский язык употребляли везде»

«Обычно, как и ко всем языкам. Люблю русский язык - он красиво звучит»

«Очень даже хорошо, я выросла здесь в России и привыкла к русскому языку, хотя дома говорю на армянском»

Преобладают преимущественно положительном отношением к русскому языку, в том числе и среди тех, кто не считает его родным. Негативных высказываний в отношении русского языка не было встречено в анкетировании.

На основе полученных данных мы можем сделать вывод о том, что в целом отношение к русскому языку среди инофонов, характеризуются высокой степенью лояльности. Дети готовы изучать русский язык, принимать культурные традиции, характерные для подавляющей массы россиян, и в целом ориентированы на успешную социализацию в российском социуме и предположительно усвоению основных национальных и этнокультурных ценностей.

Выводы:

1. Именно относительно небольшой процент ребят-инофонов 7,5\% способствует их «переплавлению» или сплачиванию с целью лучшего овладения аспектами новой для них культуры и общности на основе языка, а не ведет их к созданию национальных, религиозных или иных контркультурных социальных групп.

2. Дети 7, 8 летнего возраста осваивают русский язык с нуля в достаточной степени (это индивидуально), как правило, в течение календарного года. Процесс обучения практически выравнивается к завершению детьми начальной школы. Согласно карточкам опросов всех ребят в классах об отношении и понимании ими русского языка, дети, с 9 до 11-летнего возраста (со 2-х по 4-е классы), выравниваются в своих знаниях и общем понимании русского языка: понимании значений слов на уроках, по ТВ, в учебниках и в литературе. Дети осознают степень своей грамотности, проблемы при освоении предметов в школе, знают и видят пути разрешения встречающихся возможных или реальных затруднений. С точки зрения возрастной психологии данные результаты вписываются в систематику сенситивных периодов в развитии личности.

Общество должно принять и интегрировать представителя иной языковой среды и, в конечном счете, дать ему возможность принести пользу. Одной из проблем современного общества является симулятивность тех связей и отношений, которые существуют между людьми. Причин для этого достаточно много, но главная из них - это информационная перегрузка, воздействие на разум каждого из нас слишком большого объема информации и уже упомянутая проблема дифференциации и интеграции общества. С одной стороны, каждый человек оказывается связан со всем миром по средствам социальных сетей, телевидения, прессы. С другой - он оказывается изолирован, настоящее живое общение заменяется для него суррогатом. В этих условиях, которые еще можно назвать, «игрой в общение» у инофона, правильно интегрированного в социальную среду, оказывается целый ряд преимуществ. «Игра в общение» превращается в специфический способ снять с себя ответственность за свои слова и поступки, которой современный человек всячески стремится избежать, так же как он уменьшает количество всех возможных рисков, лишая себя повода для страха» (Фрейд, 3. Психология бессознательного. - М.: Просвещение, 1989. - 448 с., сс.386 390).

За последние годы в рассматриваемой школе нами отслеживаются постоянно имеющие место реальные примеры-доказательства успешно заканчивающих школу и вступающих в самостоятельную жизнь ребятвыпускников бывших инофонами когда-то, при поступлении к нам в школу. Данные выпускники часто вырастают и становятся яркими личностями. Они приятно радуют педагогический коллектив и оставляют учителей в уверенности, что все их усилия и труд были не напрасными, и функционирующая в школе среда оказывается эффективной и проверяется ежегодно самой жизнью. 


\section{ОСОБЕННОСТИ РАЗВИТИЯ КОММУНИКАТИВНОЙ КОМПЕТЕНТНОСТИ ОБУЧАЮЩИХСЯ В ИНТЕРАКТИВНОМ ОБРАЗОВАТЕЛЬНОМ ПРОЦЕССЕ}

Ноздрякова Елена Владимировна

Преподаватель Государственного бюджетного образовательного учреждения высшего образования

Московской области

«Технологический университет» Техникум технологий и дизайна,

2. Королев Московской области

Коммуникативная компетенция была признана еще в 1996 году международной комиссией по образованию ЮНЕСКО одной из пяти ключевых компетенций современного человека [9, с. 11]. Однако до сих пор единой системы педагогических условий для формирования компетенций обучающихся не существует. Для дальнейшего анализа необходимо уточнить разницу понятий «компетенция» и «компетентность». Обобщая определения, даваемые различными учеными (Ефремова Н.Ф., Зимняя И.А., Маркова А.К., Селевко Г.К., Хуторской А.В.), можно заключить, что:

- компетенщия - это обобщенный способ эффективной деятельности личности в некой сфере, опирающийся на совокупность знаний, умений, навыков и практический опыт;

- компетентность - это комплексное личностное образование, свидетельствующее об уровне авторитетности, правомочности личности в определенной области.

Базыльникова О.Ю. называла единую зону пересечения компетенции и компетентности - наличие знаний-умений-навыков, говоря, что «компетентность заключается в совокупности личностных качеств обучающегося, способствующих проявлению способности реализовывать знания-умения на практике... компетенция характеризует ЗУН, которым должен обладать обучающийся в соответствии с требованиями к образовательной подготовке» [1, с. 318].

Понимая коммуникативную компетентность личности как поликомпонентный внутриличностный ресурс, определяющий степень коммуникативной гибкости субъекта и уровень эффективности решения поставленных им коммуникативных задач, мы приходим к необходимости создания комплекса организационно-педагогических условий образовательного процесса для развития данной компетентности обучающихся. Анализ литературы [5] выявил разнообразные способы и технологии, предлагаемые на сегодняшний день в качестве эффективных условий развития коммуникативной компетентности обучающихся:

- дискуссии, дебаты, дискурсы, технология развития критического мышления, тренинги, в том числе с применением ИКТ-технологий (Алтунина И.Р., Булыгина Л.Н., Гейхман Л.К., Деккушева А.У., Жуков Ю.М., Китайгородская Г.А., Маркина А.А., Муравьева О.И., Нежурина Н.Ю., Петровская Л.А., Рекичинская Е.А. и др.);

- различные игры, в том числе - дидактические, театрализация (Аронсон И. [8], Букатов В.М., Губарева Т.О., Ершова А.П., Каган С., Кашлев С.С., Кавтарадзе Д.Н., Коротаева, Е.В., Панфилова А.П. и др.);

- кейс-метод и проекты (Аргунова П.Г., Карпук С.Ю., Курилова С.Ю., Малаева А.В., Маркина А.А., Полат Е.С., Пономарева Е.С., Саломатова О.С., Стрелкова А.В. и др.).

Анализируя предлагаемые способы с методологической точки зрения, можно сделать вывод, что при разнице внешней структуры организации деятельности, внутренняя сущность одинакова и основывается на многоплановом взаимодействии (т.е. интеракции) всех участников. Данный факт позволяет предположить, что наиболее эффективными для развития коммуникативной компетентности обучающихся будут условия интенсивного межличностного взаимодействия, которые возникают при интерактивном обучении. Гейхман Л.К. отмечала наличие «суммарного эффекта при интерактивном обучении общению, когда на фоне адекватного программе освоения знаний формируются умение сотрудничать... коммуникативная компетентность... толерантность, что обеспечивает полноту и адекватность общения в различных ситуациях» [2]. Разработчики кооперативного обучения Роджер и Дэвид Джонсоны особо указывали, что «навыкам лидерства, принятия решения, созданию доверия, коммуникации и управлению конфликтами надо обучать также целенаправленно и точно, как и академическим навыкам» [3, с. 92 - 93]. Кашлев С.С. подчеркивал, что «создание благоприятной, конструктивной атмосферы в отношениях участников педагогического процесса посредством применения интерактивной технологии, установление между ними многоаспектной, глубокой коммуникации - важные условия оптимального развития учащихся в педагогическом процессе» [4, с. 51]. Таким образом, интерактивное обучение можно считать базовым ресурсом для создания условий развития коммуникативной компетентности обучающихся в современном образовательном процессе.

Изучение методов и технологий интерактивного обучения привело автора к пониманию необходимости создания комплекса небольших интерактивных образовательных форм (по сути - дидактических игр), которые можно было бы встроить в композицию урока, не нарушая его целостности и не увеличивая содержание (см. табл. 1). Эти независящие друг от друга структуры цикличной деятельности основываются на разных дидактических задачах (закрепление, творческая интерпретация, овладение новым материалом, само- или взаимоконтроль) и типе взаимодействия (соревновательные, взаимообучающие, консолидирующие, творческие и пр.). Предлагаемые интерактивные формы [6; 7] универсальны (подходят 
большинству школьных предметов), не требуют особой подготовки и создают разнообразную образовательную среду взаимодействия и коммуникации обучающихся.

При формировании комплекса автором был выдвинут постулат о функциональном развитии коммуникативной компетентности обучающихся, т.е. опоре на основные пять функций коммуникации: согласование, общение, коммуникация, понимание, адаптивность. Выделенные в процессе анализа индикаторы коммуникативной компетентности по каждой функции показали правомерность ориентации на функциональность, так как в случае принятия их за независимую шкалу, можно увидеть, что каждый пункт при высоких показателях даст в сумме объективно высокую планку развития коммуникативной компетентности личности. Сообразуясь с данными функциональными направлениями, был разработан комплекс из 25 интерактивных образовательных форм структурно-кооперативного типа (дидактических игр), включивший в себя двадцать игр для урока и пять игр для внеурочной деятельности. В комплексе использованы разработки Букатова В.М., Кагана С. [10], Кашлева С.С.[4], а также представлены 18 авторских разработок Ноздряковой Е.В. (72 \% от всех игр).

ТАБЛИЦА 1.

\section{КОМПЛЕКС ИНТЕРАКТИВНЫХ ОБРАЗОВАТЕЛЬНЫХ ФОРМ СТРУКТУРНО- КООПЕРАТИВНОГО ТИПА (ДИДАКТИЧЕСКИХ ИГР) ДЛЯ РАЗВИТИЯ КОММУНИКАТИВНОЙ КОМПЕТНТНОСТИ ОБУЧАЮЩИХСЯ 15 - 17 ЛЕТ}

\begin{tabular}{|c|c|c|}
\hline $\begin{array}{c}\text { Функциональная } \\
\text { направленность } \\
\text { коммуникации } \\
\end{array}$ & $\begin{array}{c}\text { Индикаторы коммуникативной } \\
\text { компетентности }\end{array}$ & $\begin{array}{c}\text { Формы дидактической } \\
\text { кооперации обучающихся } \\
\text { (дидактические игры) }\end{array}$ \\
\hline $\begin{array}{l}\text { 1. Согласование действий } \\
\text { для достижения общего } \\
\text { результата }\end{array}$ & $\begin{array}{l}\text { 1. Я умею работать в команде, } \\
\text { стремлюсь договариваться и создавать } \\
\text { позитивный рабочий микроклимат в } \\
\text { группе } \\
\text { 2. Я способен координировать действия } \\
\text { группы людей, могу руководить или } \\
\text { подчиняться в интересах дела }\end{array}$ & $\begin{array}{l}\text { Логическая цепочка } \\
\text { Молекулярная решетка } \\
\text { Система }\end{array}$ \\
\hline $\begin{array}{l}\text { 2. Общение как } \\
\text { эмоционально- } \\
\text { когнитивный обмен } \\
\text { (эмоциями, чувствами, } \\
\text { мыслями) }\end{array}$ & $\begin{array}{l}\text { 3. Я владею приемами конструктивного } \\
\text { общения, могу вербально выразить свои } \\
\text { чувства } \\
\text { 4. Я владею невербальными приемами } \\
\text { общения } \\
\text { 5. Я могу взглянуть на ситуацию } \\
\text { глазами собеседника и понять } \\
\text { (принять) его позицию и его чувства }\end{array}$ & $\begin{array}{ll}> & \text { Встреча } \\
> & \text { Пойми меня } \\
> & \text { Мозаика чувств } \\
> & \text { Интеллектуальный } \\
\text { спарринг П } \\
> & \text { Вавилонская башня }\end{array}$ \\
\hline \multirow[b]{2}{*}{$\begin{array}{l}\text { 3. Коммуникация как } \\
\text { деятельность по } \\
\text { взаимному изменению } \\
\text { представлений друг друга, } \\
\text { взаимообучению и } \\
\text { взаимоконтролю }\end{array}$} & \multirow{2}{*}{$\begin{array}{l}\text { 6. Я стараюсь точно и ясно выражать } \\
\text { свои мысли, подтверждать свое мнение } \\
\text { аргументами } \\
\text { 7. Я умею точно сформулировать } \\
\text { вопрос, донести до собеседника свои } \\
\text { возражения, тактично отказать } \\
\text { 8. При споре я стараюсь рассмотреть все } \\
\text { точки зрения, сравнить их, увидеть } \\
\text { плюсы и минусы каждой, чтобы сделать } \\
\text { обоснованный выбор } \\
\text { 9. Я умею предвидеть и предотвращать } \\
\text { конфликты в группе } \\
\text { 10. Я могу справедливо, но тактично } \\
\text { оценить результативность своей и } \\
\text { чужой работы и выразить оценку } \\
\text { словесно }\end{array}$} & $\begin{array}{ll}> & \text { Четыре правды, одна } \\
\text { ложь } & \\
> & \text { Общее лукошко } \\
> & \text { Экспертный листок } \\
> & \text { Журналистский } \\
\text { репортаж }\end{array}$ \\
\hline & & $\begin{array}{l}>\quad \text { Здоровьесберегающий } \\
\text { контроль } \\
>\quad \text { Кураторство }\end{array}$ \\
\hline $\begin{array}{l}\text { 4. Обеспечение понимания } \\
\text { за счет владения } \\
\text { коммуникативными } \\
\text { конструкциями в } \\
\text { соответствии с } \\
\text { лингвистическими } \\
\text { нормами общества } \\
\end{array}$ & $\begin{array}{l}\text { 11. Я владею различными речевыми } \\
\text { конструкциями и формами общения } \\
\text { (монолог, диалог, полилог; устная / } \\
\text { письменная речь; контактная или } \\
\text { виртуальная форма взаимодействия) } \\
\text { 12. Я обладаю грамотной речью, } \\
\text { богатой лексикой }\end{array}$ & $\begin{array}{ll}> & \text { Выбери слова } \\
> & \text { Перевод } \\
> & \text { Образ текста } \\
> & \text { Пойди туда - не знаю } \\
\text { куда... } & \\
> & \text { Стратегия РАФТ } \\
> & \text { Перекрестные группы } \\
\end{array}$ \\
\hline \multirow{2}{*}{$\begin{array}{l}\text { 5. Коммуникативная } \\
\text { адаптивность личности, } \\
\text { включающая в себя } \\
\text { когнитивно-регулятивный }\end{array}$} & \multirow{2}{*}{$\begin{array}{l}\text { 13. Я всегда знаю, какова цель моего } \\
\text { общения, ориентируюсь на неё в } \\
\text { речевом взаимодействии и стараюсь её } \\
\text { достигать }\end{array}$} & $\begin{array}{l}\text { Всеобщие связи } \\
\text { Угол зрения } \\
\text { Метаморфозы }\end{array}$ \\
\hline & & Рефлексивный экран \\
\hline
\end{tabular}




\begin{tabular}{|l|l|l|}
\hline $\begin{array}{l}\text { и рефлексивно-оценочный } \\
\text { элемент }\end{array}$ & $\begin{array}{l}\text { 14. Я могу быстро поменять стиль } \\
\text { общения и форму речи в изменившейся }\end{array}$ & Рефлексивная ромашка \\
& ситуации & \\
& 15. Я могу в процессе общения точно & \\
& оценить, насколько я им доволен и при & \\
необходимости скорректировать его & \\
\hline
\end{tabular}

Пример интерактивной игры «Общее лукошко» (автор - Ноздрякова Е.В.), рассчитанной на возраст обучающихся от 12 до 18 лет. Реквизит: листы с разным текстом в 4 - 5 местах класса. Класс делится на группы по 4-5 человек в каждой. Перед группами ставится вопрос, формулируется проблема, для ответа на который необходима дополнительная информация, лежащая в 4-5 местах класса. Время на ознакомление с информацией и выработку группового мнения - 5 минут. Для слабых групп задаются вопросы на планирование деятельности (Как познакомиться со всей информацией? - разделиться и послать представителей; Как её запомнить, если записывать нельзя и уносить листы тоже нельзя? - пересказать друг другу). По сигналу - группы разделяются на отдельных членов, и каждый бежит запоминать свой кусок текста, затем - группы снова собираются вместе, неся свой вариант решения в «общее лукошко», их задача - пересказать внутри группы друг другу свои тексты, обсудить и выбрать единственное решение. По окончании 5 минут группы по очереди выступают, педагог комментирует, общее подведение итогов. Рефлексия: В ходе заключительного обсуждения группы комментируют внутригрупповое взаимодействие в процессе работы и личную степень удовлетворенности, каждый участник имеет возможность поделиться своими сомнениями, недовольством или задать вопрос. Игра имеет хороший резонанс, мотивирует обучаюшихся, повышает познавательную активность, развивает несколько функций коммуникации: согласование, взаимообучение, самоконтроль, понимание, адаптивность личности.

Данный комплекс стал основой для разработки содержательно-функциональной модели развития коммуникативной компетентности обучающихся 15 - 17 лет в процессе урочной и внеурочной деятельности, для успешного внедрения которой в образовательный процесс необходимо опираться на пять специфических принципов:

> Принцип систематичности, основывающийся на регулярности, системности и последовательности использования дидактических игр данного комплекса, соблюдая предложенное автором функциональное разделение;

> Принцип вариативности предусматривает возможность вариантов осуществления деятельности при взаимодействии в группе, параллельное формирование различных компетенций обучающихся при выполнении одного и того же полифункционального задания (ловля «101 зайца» по Букатову В.М.);

> Принцип полифонии заключается в создании условий для интенсивного полифункционального общения обучающихся, обеспечение смены деятельности и групповых ролей (от лидера до рядового подчиненного, от обучающегося до контролера);

$>$ Принци сознательности подразумевает развитие личностного целеполагания, планирования, рост самоконтроля и саморегуляции личности, формирование стремления к результату и развитие коммуникативных способностей по анализу и оценке своей и чужой деятельности;

$>$ Принцип динамичной структуры обуславливает структурированность деятельности и коммуникации групп, имеющую свой темп и ритм, наличие регламента по времени.

Рекомендуемый для педагога порядок включения интерактивных форм (дидактических игр) в образовательный процесс имеет 4 этапа:

1) Включение в образовательный процесс несложных интерактивных игр на согласование действий обучающихся, умение договариваться в процессе творческой интерпретации учебного текста и рефлексию (1, 4 и 5 блок в части рефлексии);

2) Добавление интерактивных форм на формирование навыков деловой коммуникации, само- и взаимоконтроля, развитие лингвистических навыков (3, 4 и 5 блок в части рефлексии);

3) Важный и сложный этап овладения навыками невербального общения, обмена эмоциями и рефлексией (акцент на внеурочную деятельность), а также продолжение формирования навыков деловой коммуникации (приемы активного слушания) (2, 3, 4 и 5 блок в части рефлексии);

4) на заключительном этапе предлагаются интерактивные формы на коммуникативную адаптивность личности, развивающие умение быстрой оценки ситуации и перестройки собственной коммуникации под изменившиеся обстоятельства $(5,1,23$ блоки).

Предлагаемый порядок внедрения интерактивных образовательных форм (дидактических игр) носит рекомендательный характер, может иметь варианты, не являясь строгой структурой (в отличие от технологии), так как каждая из интерактивных форм имеет собственное целеполагание, замкнутый цикл и развивающий потенциал, чем выгодно отличается от алгоритмизированной технологии, где один этап зависит от другого.

Успешно проведенный эксперимент в 2015 - 2018 годах в нескольких образовательных учреждениях Москвы и Московской области подтвердил целесообразность включения интерактивных образовательных 
форм структурно-кооперативного типа в урочную и внеурочную деятельность обучающихся в качестве главного условия развития коммуникативной компетентности обучающихся.

\title{
Библиография
}

1. Базыльникова, О.Ю. Соотношение ведущих понятий теории компетентностного подхода [Текст] / О.Ю. Базыльникова // Психология и педагогика: методика и проблемы практического применения. 2011. - № 20. - С. 315 - 320 .

2. Гейхман, Л.К. Обучение общению на основе взаимодействия с Другим / Л.К. Гейхман // Вестник ОГУ. 2002. - № 7. - С. 28 - 34 .

3. Джонсон, Д. Кооперативное обучение возвращается в колледж. Какие свидетельства есть тому, что оно работает / Д. Джонсон, Р. Джонсон, К. Смит // Дидактика высшей школы; отв. ред. М. А. Гусаковский [и др.]. - Мн.: БГУ, 2005. - 162 с.

4. Кашлев, С.С. Интерактивные методы обучения: учеб.- метод. пособие / С.С. Кашлев. - 2-е изд. Минск: ТетраСистемс, 2013. - 224 с.

5. Ноздрякова, Е.В. Системно-функциональный анализ способов активизации обучения в контексте современного образования / Е.В. Ноздрякова // Международный журнал прикладных и фундаментальных исследований. - 2016. - № 2, ч. 3 - С. 375 - 378.

6. Ноздрякова, Е.В. Интерактивные образовательные формы как оптимальные условия развития коммуникативной компетентности обучающихся в контексте классно-урочной системы / Е.В. Ноздрякова // Современные проблемы науки и образования. - 2017. - № 2.

7. Ноздрякова, Е.В. Интерактивные образовательные формы как системообразующий фактор современного обучения / Е.В. Ноздрякова // Интерактивное образование. Информационнопублицистический образовательный журнал - 2018. - № 1-2. - С. 22-24

8. Aronson, E. Jigsaw in 10 Easy Steps. URL: http://www.jigsaw.org/steps.htm

9. Hutmacher Walo. Key competencies for Europe//Report of the Symposium Berne, Switzerland 27-30 March, 1996. Council for Cultural Co-operation (CDCC) //Secondary Education for Europe Strasburg, 1997.

10. Kagan, S. The Structural Approach to Cooperative Learning - Educational Leadership, December 1989/ January 1990 by the Association for Supervisi on and Curriculum Development (USA). URL: http://www.ascd.org/ASCD/pdf/journals/ed_lead/el_198912_kagan.pdf

\section{УДК: 373.291.(571.54)}

\section{ПОЗНАВАТЕЛЬНО ИССЛЕДОВАТЕЛЬСКАЯ ДЕЯТЕЛЬНОСТЬ В ДОО}

Полина Петровна Бартаева

Стариий преподаватель кафедры педагогики и психологии детства Бурятский Республиканский Институт Образовательной Политики 670000, Россия г. Улан-Удэ ул. Советская, 30

\section{COGNITIVE AND RESEARCH ACTIVITIES IN THE PEE}

\author{
Polina Petrovna Bartaeva \\ Senior Lecturer at the Department of Pedagogy and Psychology of Childhood \\ Buryat Republican Institute of Educational Policy \\ 670000, Russia, Ulan-Ude, Sovetskaya St., 30
}

\begin{abstract}
Аннотация. В статье материал опытно-экспериментальной деятельность детей дошкольного возраста. Формирование у детей познавательно - исследовательской деятельности актуальная тема в современном мире. Проанализированы теоритические основы познавательной - исследовательской деятельности детей старшего дошкольного возраста. Детская активность непосредственно связана с активностью воспитателя, знания и умения ребенок получает, усваивает при помощи взрослого. Исследовательская деятельность позволит вырасти детям любознательными, сообразительными. В статье выделенные направления и условие для развития познавательного интереса у детей дошкольного возраста. Данный вид деятельности очень сложный для детей, требует не только сформированность ранее полученных навыков, но и понимание ребёнком смысла проводимых им действий. Ребёнок прирождённый исследователь, ему свойственно быть любопытным, интересоваться всем, что происходит вокруг. Формирование и развитие познавательноисследовательской деятельности организуется в форме партнёрской деятельности воспитателей и детей. Период открытий и увлечений, любознательность у детей приходится на старший дошкольный возраст познавательный потенциал приобретает новые формы, желание познавать совпадает с интеллектуальными возможностями, что означает благоприятное время для развития ребёнка.

Abstract. The material of the experimental activity of preschool-aged children is given in the article. The formation of cognitive and research activity in children is an actual topic in the modern world. Theoretical foundations of cognitive and research activities of preschool-aged children were analyzed. Children's activity is directly related to the activity of the educator, the child receives knowledge and skills, assimilates them with the help of an adult. Research activities allow children to grow up to be curious, quick-witted. The directions and
\end{abstract}


conditions for the development of cognitive interest in preschool-aged children are highlighted in the article. This type of activity is very difficult for children; it requires not only the formation of previously acquired skills but also the child's understanding of the meaning of the actions he/she performs. A child is a born researcher, it is common for him/her to be curious, to be interested in everything happening around. The formation and development of cognitive research activity are organized in the form of partnership activities of educators and children. The period of discoveries and enthusiasm, curiosity in children falls on the older preschool age, the cognitive potential reshapes, the desire to learn coincides with the intellectual possibilities, which means a favorable time for the development of the child.

Ключевые слова: Познавательно - исследовательская деятельность, элементарное экспериментирование, познавательное развитие детей дошкольного возраста, познавательный интерес, актуализация знаний в исследуемой проблеме.

Keywords: Cognitive and research activities, elementary experimentation, cognitive development of preschool-aged children, cognitive interest, the actualization of knowledge on the studied problem.

\section{Введение}

Дошкольный возраст считается наилучшим для развития познавательных способностей в целом. Поэтому развитие познавательных процессов наилучшим образом приходятся именно на этот возраст. Интерес к познанию сам по себе является залогом успешного обучения в жизни. Всеми известно, что окружающий мир привлекает внимание детей. Еще не осознавая ребенок видит перспективу собственного развития, которая проявляется в момент познания и исследования чего-то нового и неизвестного. Доминируя над детьми, не давая им познавать и исследовать - то ребенок не приобретет личностные черты, не научится размышлять, делать выводы, находить решения и объяснять происходящее.

Проявляя любознательность дети дошкольного возраста получая опору в лице взрослых начинают познавать мир, ориентируются в окружающей среде и выработают свои представления. Изучая представления детей об окружающем мире, можно убедится в том, что ребенок с радостью познает и проявляет интерес к новому и загадочному миру.

Познавательно - исследовательская деятельность создает условия для обогащения развития ребенка. Она позволяет спроектировать условия возникновения таких психических способностей и свойств, которыми ребенок пока не обладает, направить процесс их становления не только извне - через побуждение, но и изнутри - путем построения деятельности, педагога и ребенка ${ }^{1}$ [1, с. 24].

Данная деятельность имеет высокое значение после утверждения федерального государственного образовательного стандарта дошкольного образования, где определено познавательное развитие детей, любознательности и формирование познавательных действий ${ }^{2}$ [2, с.112].

При взаимоотношении детей со взрослыми изучения окружающего мира положительно влияет на познавательную деятельность. Дети, имеющие рядом с собой взрослого, взаимодействуют с ним, не боятся окружающего мира и активно его исследуют. Взаимодействие со взрослым, общение с ним положительно влияют на познавательную активность ребенка, дают значительный импульс к его исследовательской деятельности. Как показала практика, большинство детей с удовольствием проводят разнообразные исследования. Поэтому им необходимо создать условия для самостоятельного нахождения ответов на интересующие вопросы. Дети с удовольствием рассказывают о своих открытиях родным и близким, и в дальнейшем учатся ставить новые задачи и самостоятельно решать их.

Важно дать ребёнку проблему, что б ребёнок нашел пути решения, делая выводы. Главное- не боятся пробовать, давать возможность детям экспериментировать, ставить опытно- экспериментальную деятельность и помогать делать выводы самостоятельно.

\section{Методология и методы исследования, результаты исследования}

Проанализировав работу ученых Н.Е. Веракса, Н.Н. Поддъякова, Л.А. Парамонова по формированию поисковой деятельности детей старшего дошкольного возраста, изучив программу «Ребёнок в мире поиска» разработчики программы О.В. Дыбина, В.В. Щитинина- пришла к выводу, что осуществляемые ребенком практические действия выполняют, познавательную, ориентировочно-исследовательскую функцию, создавая условия, в которых раскрывается содержание данного объекта. Ребенок - дошкольник сам по себе уже является исследователем, проявляя живой интерес к различного рода исследовательской деятельности - к экспериментированию. Опыты помогают развивать мышление, логику, творчество ребенка, позволяют наглядно показать связи между живым и неживым в природе. Элементарное- экспериментирование направлено на изучения детьми связей между разными предметами и явлениями окружающего мира.

Переосмысления того как и чему учить детей. Ведущей вид деятельности в детском саду игра- с ее помощью детям легче и интереснее познается мир и окружающая действительность. Интерес детей

\footnotetext{
${ }^{1}$ Батова, И. С. Познавательно-исследовательская деятельность детей. Опыты и эксперименты с веществами и материалами. Зима. Подготовительная группа (6-7 лет): комплект из 16 технологических карт / И.С. Батова. - М.: Учитель, 2019. - С. 24

${ }^{2}$ Бурнышева, М. Г. Развитие познавательной активности детей через экспериментально-исследовательскую деятельность./ М. Г. Бурнышева // Дошкольная педагогика. - 2016. - №3. - С. 112 
дошкольного возраста издавна является предметом пристального внимания мыслителей и ученных. «Воспитатель не должен забывать, что учение, лишённое всякого интереса и взятое только силой принуждения... убивает в ученике охоту к учению, без которого он далеко не уйдет», - писал К.Д. Ушинский. В современных условиях внедрения в практику дошкольных образовательных организации ФГОС ДО проблемы формирования познавательного интереса дошкольников вновь становится актуальной. ${ }^{1}$ [9, с.5]. Детство - самая счастливая пора в жизни человека. Дошкольник энергичен и активен. Его притягивает практически все, он мучает вопросами взрослых, пытается многое узнать и понять. Основное правило, которое должен запомнить взрослый: он призван помогать ребенку, создавать условия для познания мира.

Современные дети живут в эпоху информатизации и компьютеризации. В условиях быстро меняющейся жизни от человека требуется не только владение знаниями, но и в первую очередь умение добывать эти знания самому и оперировать ими, смыслить самостоятельно и творчески.

Цель- формирование у дошкольника первоначальных навыков в поисковой деятельности, а также применение полученных путем исследовательской работы знаний с дальнейшим решением необходимой проблемы.

Задачи- это необходимость развить у дошкольника познавательные способности, творческое мышление и коммуникативные навыки.

$>$ Развивать предпосылки к диалектическому мышлению, способности познавать окружающий мир.

$>$ Расширять познавательно- исследовательскую деятельность путем элементарного экспериментирования.

> Формировать познавательную активность и самостоятельность, представления, определяющие целостную картинку мира.

Главное создать все необходимое для познавательно- исследовательской деятельности. Элементарное экспериментирование должно соответствовать возрасту детей их интересам, умению делать выводы и находить решение проблемы. Наблюдая за детьми, я пришла к мнению, всё что дети не могут объяснить для них это «волшебство». В нашем современном мире, новые технологии, много разных технических возможностей, но мы взрослые забываем о том, что методом проб и ошибок дети познают мир. Для этого не обходимо проводить с детьми элементарное- экспериментирование, чтоб дети принимали активное участия, только попробовав самостоятельно дети смогут сделать вывод и найти решение проблемы или объяснить происходящие. При помощи исследования дети приобретают навыки, умения, знания, происходит расширение и активация словаря детей дошкольного возраста. Поэтому важно чтоб элементарное- экспериментирование проходило в детском саду систематически в форме игры, чтоб дети решали проблемы и находили разные варианты ответов.

Успешность и самостоятельность исследовательской деятельности детей дошкольного возраста зависит от поисково- информационных умений в соответствии с особенностями проблемы и этапов исследования. Особое внимание нужно уделить воспитателю на взаимосвязь познавательноисследовательской деятельности реализацию в соответствии с ФГОС ДО. В основы познавательноисследовательской деятельности нужно заложить в деятельность, что не нужно давать детям готовую информацию, а дать все в виде проблемной ситуации - провокация детей в режимном моменте, дать самостоятельно дошкольникам необходимость решетить проблему, руководствуясь ранее полученными знаниями и закрепление их.

\section{Результаты исследования и их обсуждение}

Проанализировав воспитательно-образовательный процессии проведя диагностическое исследования по методике «Маленький исследователь» Л. Н. Прохоровой, помогающая выявить степень устойчивости интересов ребенка; исследовать предпочитаемые детьми материалы в процессе экспериментирования, на начало 2019 года получены такие результаты:

5\% детей- высокий уровень дети отличились тем, что способны сформулировать достигнут результат или нет, а также устанавливают разнообразные временные, последовательные, причинные связи, делают самостоятельные выводы.

$47 \%$ детей- средней уровень . Дети со средним уровнем чаще всего формулировали выводы при помощи педагога и пользуются аргументами и суждениям с помощью взрослого.

$48 \%$ детей - низкий уровень. Дети с низким уровнем практически не делают выводы даже при помощи взрослых, а также ориентируются только на внешние несущественные особенности материала.

Исследовательскую деятельность можно рассмотреть как форму активности и нового формата изучения и приобретения детьми нового опыты и знаний, при решении поставленный задач или проблемной ситуации.

При организации основы познавательно- исследовательской деятельности, всех ее разновидностей следует опираться на личностно ориентированный и деятельностный подход, что позволит каждому ребенку выступать как самостоятельный объект при выполнении поставленной проблемы. В процессе элементарного- экспериментирования педагогу не обходимо выстроить свои взаимоотношения с детьми так,

\footnotetext{
${ }^{1}$ Фришман, И. И. Теоретические основания формирования познавательного интереса дошкольников / И. И. Фришман // Познавательное развитие дошкольников: теоретические основы и новые технологии. - М.: Русское слово, 2015. - С.5
} 
чтобы стимулировать и одновременно дать самостоятельность в работе.

Практика показала, что дети с удовольствием «превращаются» в ученых и проводят разнообразные исследования, нужно лишь создать условия для самостоятельного нахождения ответов на интересующие вопросы, но дети не умеют делать выводы, занимательные опыты, эксперименты побуждают детей, проявлению творчества, так как представлены с учетом актуального развития дошкольников.

\section{Выводы}

Дети с удовольствием рассказывают о своих открытиях родителям, ставят такие же (или более сложные), опыты дома, учатся ставить новые задачи и самостоятельно решать их.

Для более полного погружения детей в исследовательскую деятельность необходимо оборудовать постоянное место пребывания дошкольников различными предметами на все возможные темы. Желательно предложить детям разнообразные формы организации познавательно- исследовательской деятельности - в зависимости от индивидуальных особенностей детей. Для детей дошкольного возраста нужно использовать - игры- ситуации, дидактические игры, сюрпризные моменты, содержащие элементы новизны, что будет стимулировать детей вести диалог с педагогом. Дети радуются новому открытию, имеют опору на жизненный опыт, происходит развитие эмоций, развитие воображения (всякое эмоциональное возбуждение ведет к работе воображения).

\section{Список литературы.}

1. Батова, И. С. Познавательно-исследовательская деятельность детей. Опыты и эксперименты с веществами и материалами. Зима. Подготовительная группа (6-7 лет): комплект из 16 технологических карт / И.С. Батова. - М.: Учитель, 2019. - 16 с.

2. Бурнышева, М. Г. Развитие познавательной активности детей через экспериментальноисследовательскую деятельность./ М. Г. Бурнышева // Дошкольная педагогика. - 2016. - №3. - С. 24-26.

3. Вахрушева, Л.Н. Воспитание познавательных интересов у детей 5-7 лет / Л. Н. Вахрушева. - М.: ТЦ «Сфера», 2012. - 128 c.

4. Рыжова, Л. Методика детского экспериментирования / Л. Рыжкова. - М.: Детство-Пресс, 2015. - 208

c.

5. Фришман, И. И. Теоретические основания формирования познавательного интереса дошкольников / И. И. Фришман // Познавательное развитие дошкольников: теоретические основы и новые технологии. - М.: Русское слово, 2015. - С.5-9

6. Щукина, Г. И. Формирование познавательного интереса в педагогике / Г. И. Щукина. - М.: Просвещение, 2010. - 230 с.

7. Кочурова, Елена Эдуардовна Исследуем свойства предметов [Текст] : пособие для детей 5-7 лет / Е. Э. Кочурова. - Москва : Вентана-Граф, 2016. - 48 с. : цв. ил. ; 26 см. - (Предшкольная пора) (ФГОС). ISBN 978-5-360-07724-4

8. Веракса, Николай Евгеньевич. Проектная деятельность дошкольников [Текст] : пособие для педагогов дошкольных учреждений : для работы с детьми 5-7-и лет / Н. Е. Веракса, А. Н. Веракса. Москва : Мозаика-Синтез, 2008. - 112 с. : фот. ; 24 см. - (Библиотека программы воспитания и обучения в детском саду). - ISBN 978-5-86775-643-7

9. Познавательное развитие дошкольников [Текст] : теоретические основы и новые технологии : сборник статей / ФГБ НУ "Институт психолого-педагогических проблем детства РАО" ; авторысоставители: Т. В. Волосовец, И. Л. Кириллов, Л. М. Кларина. - Москва : Русское слово, 2015. - 128 с. ; 22 см. - (ФГОС ДО) (Мозаичный ПАРК). - ISBN 978-5-00007-959-1

10. Дыбина, Ольга Витальевна. Неизведанное рядом [Текст] : опыты и эксперименты для дошкольников / О. В. Дыбина, Н. П. Рахманова, В. В. Щетинина. - 2-е издание, исправленное. - Москва : Сфера, 2014. - 188 с. : ил. ; 20 см. - (Ребенок в мире поиска). - Библиография: с. 186. - ISBN 978-5-99490369-8

11. Дыбина, Ольга Витальевна. Ребенок в мире поиска : программа по организации познавательноисследовательской деятельности дошкольников / О. В. Дыбина, В. В. Щетинина, Н. Н. Поддьяков. Москва : Сфера, 2017. - 127 с. : табл. ; 21 см. - (Ребенок в мире поиска). - ISBN 978-5-9949-1850-0

12. Как организовать проект с дошкольниками [Текст] / автор-составитель А. А. Сидорова. - Москва : Сфера, 2016. - 121, [2] с. : табл. ; 21 см. - (Управление детским садом) (Соответствует ФГОС ДО). - ISBN 978-5-9949-1358-1

13. Гуцал, Ирина Юрьевна. Познавательные путешествия [Текст] : интегрированные занятия для детей 5-7 лет : [пособие] / И. Ю. Гуцал, Г. В. Мищенко. - Москва : ТЦ Сфера, 2017. - 63 с. ; 21 см. - (Библиотека логопеда). - Библиография: с. 61-62. - ISBN 978-5-9949-1736-7

\section{References}

1. Batova, I. S. Educational and research activities of the children. Experiments and experiments with substances and materials. Winter. Preparatory group (6-7 years): a set of 16 technological maps / I. S. Batova. - M.: Teacher, 2019. - 16 p. 
2. Burnysheva, M. G. development of cognitive activity of children through experimental research activities./ M. G. Burnysheva / / Preschool pedagogy. - 2016. - №3. - P. 24-26.

3. Vakhrusheva, L. N. Education of cognitive interests in children 5-7 years / Ln Vakhrusheva. - M.: shopping center Sfera, 2012.

4. Ryzhov, L. children's experimentation / L. Ryzhkov. - Moscow: Childhood Press, 2015. - 208 p.

5. Frishman, I. I. Theoretical bases of formation of cognitive interest of preschool children / I. I. Frishman / / Cognitive development of preschool children: theoretical bases and new technologies. - Moscow: Russian word, 2015. - P. 5-9

6. Formation of cognitive interest in pedagogy / G. I. Shchukin. - Moscow: Education, 2010. - 230 p.

7. Kochurova, Elena Eduardovna Explore the properties of objects [Text]: a guide for children 5-7 years / E. E. kochurova. - Moscow : Ventana-Graf, 2016. - 48 p.: CV. slime. ; 26 cm. - (pre-School time) (GEF). - ISBN 9785-360-07724-4

8. Veraksa, Nikolai Evgenievich. Project activities preschoolers [Text] : a Handbook for teachers of preschool institutions for work with children 5-7 years / N. E. Veraksa, A. N. Verax. - Moscow: Mosaic-Synthesis, 2008. - 112 p.: fot. ; 24 see - (Library of the program of education and training in kindergarten). - ISBN 978-5-86775643-7

9. Cognitive development of preschool children [Text]: theoretical foundations and new technologies: collection of articles / FSB NU "Institute of psychological and pedagogical problems of childhood RAO" ; authors: T. V. Volosovets, I. L. Kirillov, L. M. Klarina. - Moscow: Russian word, 2015. - 128 p.; 22 cm. - (GEF DO) (Mosaic PARK). - ISBN 978-5-00007-959-1

10. Dybina, Olga Vitalievna. Unknown near [Text]: experiments and experiments for preschoolers / O. V. dybina, N. P. Rakhmanova, V. V. Shchetinina. - 2nd edition, revised. - Moscow: Sphere, 2014. - 188 p.: Il. ; 20 cm. - (Child in the world of search). - Bibliography: p. 186. - ISBN 978-5-9949-0369-8

11. Dybina, Olga Vitalievna. Child in the world of search: the program for the organization of cognitive research activities of preschool children / O. V. dybina, V. V. Shchetinina, N. N. Poddiakov. - Moscow: Sphere, 2017. 127 p.: table. ; $21 \mathrm{~cm}$. - (Child in the world of search). - ISBN 978-5-9949-1850-0

12. How to organize a project with preschoolers [Text] / author-compiler AA Sidorova. - Moscow: Sphere, 2016. - 121, [2] p.: table. ; $21 \mathrm{~cm}$. - (the Management of the kindergarten) (Corresponding TO GEF). - ISBN 978-59949-1358-1

13. Gutsal, Irina Yurievna. Discovery trip [Text] : integrated classes for children 5-7 years : [textbook] / I. Yu. Gutsal, G. V. Mishchenko. - Moscow: SC Sphere, 2017. - 63 p.; $21 \mathrm{~cm}$. - (library speech therapist). Bibliography: p. 61-62. - ISBN 978-5-9949-1736-7

\title{
НЕОБХОДИМОСТЬ И ВОЗМОЖНОСТИ ФОРМИРОВАНИЯ ГРАЖДАНСКОЙ ИДЕНТИЧНОСТИ ОБУЧАЮЩИХСЯ КОЛЛЕДЖА
}

\author{
Тазетдинова Елена Николаевна, \\ преподаватель государственного автономного \\ профессионального образовательного учреждения \\ «Иркутский колледж экономики, сервиса и туризма»,
}

Иркутск

Новые социально-экономические условия в стране изменили не только структуру профессиональной деятельности специалистов различных отраслей, но и условия их подготовки. Связь ФГОС и профессиональных стандартов должны обеспечить востребованность выпускников на рынке труда. В месте с тем целостный образовательный процесс профессиональной образовательной организации не может быть реализован только за счет дисциплин учебного плана без воспитания и формирования профессионально значимых качеств специалиста. Большинство профессионально значимых качеств совпадают для широкого круга специальностей, хотя имеются качества, присущие определенным группам специальностей.

Анализ научной литературы показал, что существуют инвариантные профессионально значимые качества, присущие специалисту любого профиля. Однако, специалистам определенной квалификации присущи специфические, характерные в основном только для этой категории специалистов. Например, имеют место свои профессионально-значимые качества работники образования, медицинские работники, работники сервисного обслуживания, специалисты технического профиля и т.д. Выявление этих качеств представляет собой достаточно сложную педагогическую проблему. Определенные путем педагогических исследований профессионально значимые качества специалистов, как правило, отражаются в профессиональных стандартах или законодательных актах, регламентирующих профессиональную деятельность специалистов.

Например, в Указе Президента Российской Федерации «О мерах по совершенствованию деятельности органов внутренних дел Российской Федерации» в числе важнейших причин, вызвавших необходимость модернизации данной системы, было названо несоответствие кадрового обеспечения современным требованиям. В Дорожной карте дальнейшего реформирования органов внутренних дел Российской Федерации предлагается разработать научно обоснованные мероприятия, направленные на формирование 
высококвалифицированного и ответственного специалиста, способного по своим профессиональным, личным, деловым и морально-психологическим качествам эффективно выполнять возложенные задачи. Более того, Федеральные законы и Правительственные акты, регламентирующие профессиональную деятельность служащих правоохранительных органов, устанавливают повышенные требования к гражданским качествам личного состава. Современный юрист должен владеть системой профессиональных знаний, осознавать значимость выполнения профессионального долга, понимать цели и нравственный смысл государственной службы, а также демонстрировать высокий уровень культуры, выстраивать свою деятельность, исходя из осознания ответственности за принятые решения, ценностей гуманизма, патриотизма, справедливости.

Если специалист является государственным гражданским служащим, то его профессиональная деятельность содержит в себе огромный моральный потенциал, так как он призван осуществлять свои профессиональные компетенции, непосредственно затрагивая права и интересы людей. Каждый день, сталкиваясь с ситуациями морального выбора, такой специалист должен обладать, помимо профессиональных знаний и умений, такими личностными качествами и системой ценностных установок, в опоре на которые он оказался бы способным решать профессиональные задачи. [8, с. 49-51].

Для специалистов судебного администрирования выделяют: систему нравственных ценностей, обращая внимание на культивирование патриотизма, честности, гуманности и принципиальности. Специальная направленность включает в себя понимание сущности и социальной значимости своей специальности; самореализацию посредством профессиональной деятельности.

Специалист по социальной работе ответственен за воспитание семей с детьми, молодежи, лиц, попавших в трудную жизненную ситуацию, становление и развитие гуманистической, духовнонравственной сферы социальной жизни общества, за творческий потенциал общества и становление его моральных ценностей. Эти задачи раскрываются в трудах ученых В.Г. Бочаровой, Б.Т. Лихачева, А.В. Мудрика, Л.И. Новиковой и других.

Изучение государственных документов, нормативно-правовой базы, рассматривающих профессиональную деятельность специалистов экономического профиля, нравственное воспитание определяется как важнейший компонент успешной трудовой деятельности. Осознание обучающимся экономического направления личностной значимости нравственного поведения содействует процессу перевода ее объективного значения в субъективный смысл, превращению в жизненно важную задачу, которая становится реальным смыслом активного включения в процесс воспитания и качественного усвоения, необходимых для успешной профессиональной деятельности не только знаний, умений и навыков, но и профессиональных компетенций [6, с. 45].

Формирование профессионально значимых качеств специалиста любого профиля происходит в процессе его профессионального становления. Э.Ф. Зеер дает такое определение сущности этого понятия: «Мы понимаем профессиональное становление личности как развитие личности в учебно-профессиональной деятельности, направленное на формирование устойчивых положительных мотивов профессиональной деятельности, социально-значимых и профессионально важных качеств личности, готовности к постоянному профессиональному росту. Нахождения оптимальных приёмов и способов качественного и творческого выполнения профессиональной деятельности в соответствии и индивидуально-психологическими особенностями личности специалиста» [5, с. 65].

На основе анализа специальной литературы, освещающей вопросы подготовки соответствующих направлений, было высказано предположение, что таким профессионально значимым качеством личности будущего специалиста является гражданская идентичность. Обоснованием этого явилось следующее. Культура российского общества при всех ее инновациях содержит характерные начала преданности государству, верности Отечеству. Названные качества являются не только качествами одной личности, но и основными факторами формирования всего российского общества. Это крайне важно для специалистов правоохранительной и государственной гражданской службы, и является традиционно значимой составляющей российского общества. В этой связи основой гражданской идентичности будущих специалистов выступает готовность достойно служить на благо государства. Такая готовность представляется как социально-педагогический феномен, который предопределен требованиям общества и государства к личности соответствующего специалиста. Названный феномен, являясь результатом подготовки и воспитания молодых людей к осуществлению задач по защите государства и граждан, выражается в реальной способности осуществить такие задачи [7].

Характеризуя особенность подготовки специалистов соответствующего направления, необходимо исходить из того, что к ценностям, на основе которых строится правоохранительная и государственная гражданская служба, относятся: во-первых, гражданский долг, как потребность личности в высоконравственном, ответственном отношении к социальным, государственно-значимым нормам и требованиям своей страны; во-вторых, профессиональный долг, представляемый как некая система ценностей, значимых для социума, в том числе морально-правовых обязанностей, постоянная готовность к самопожертвованию во имя интересов Родины, закрепленная в нормативно-правовых документах; втретьих, профессионализм высокий уровень овладения специалистами, профессиональными знаниями и умениями, служебными обязанностями по предназначению и вместе с тем способность успешно выполнять 
поставленные служебные задачи. Об этом говорится в работе С. С. Алексеева, а именно, что профессиональная деятельность, юриста в большей степени, может осуществляться только в органическом единстве с ценностями человека и гражданина [2, с. 12].

А.П. Коренев считает, что «профессии юриста присущи общие черты, которые не зависят от вида выполняемой специалистом этого профиля работы. К таким чертам относятся: гуманизм и справедливость; государственный характер; психолого-педагогическая направленность; творческий, исследовательский характер; самостоятельность и независимость в принятии решений; организаторский характер; формализованность» [1, с. 127-130].

В 80-х годах прошлого столетия С.С. Алексеев и В.Ф. Яковлев, разработали модель правозащитника. Основными общими показателями, по их мнению, являлись: марксистско - ленинская идейность, политическая зрелость, принципиальность, правильное понимание своего общественного государственного долга; высокий и «специализированный» нравственный уровень, подчинение деятельности юриста ряду этических норм [3, с. 73-81].

Процесс формирования гражданской идентичности в практике среднего профессионального образования, осложняется отсутствием разработанных педагогических подходов. Кроме того вне специального научного исследования остается вопрос о способах включения процесса формирования гражданской идентичности в содержание образования, рассматриваемого на различных уровнях. Неразработанность обозначенной проблемы приводит к тому, что в системе среднего профессионального образования у обучающихся гражданские качества формируется преимущественно эмпирически, т.е. без необходимого научного обоснования. Это обуславливает известную стихийность такой деятельности, и, следовательно, ее невысокую эффективность.

Проблема социальных функций образования оказывалась в центре внимания классических и современных концепций образования. Социальные функции образования прослеживаются в педагогических теориях М.В. Ломоносова, который связывал развитие отечественного образования с судьбой России. Зарубежные ученые на основе анализа современных темпов развития социально-политических, экономических изменений, повышающих для многих риск потерять прочную опору в жизни, пришли к выводу, что менее всего подвержены те, у кого социальная мобильность развита лучше остальных граждан. Это особенно актуально для будущих специалистов, осуществляющих задачи по обеспечению стабильности в обществе и государстве.

В этой связи необходимо отметить, что назначение гражданской идентичности специалистов правоохранительной и государственной гражданской службы отлично от других социальных и профессиональных слоев общества. Гражданская идентичность дает им возможность понимания государственных и социальных форм жизни на современном этапе развития общества, что способствует восприятию нового в общественной жизни. Подчеркнем, что выпускники профессиональных образовательных организаций переносят в государственные структуры свои убеждения и взгляды. Степень социальной адаптации и государственной социализации поступающей молодежи имеет важное значение для формирования профессиональных коллективов. Укрепление служебной дисциплины, реализация принципов единоначалия, беспрекословности подчинения младших по рангу старшим, не обсуждаемости приказов наиболее эффективно обеспечиваются на базе гражданского самосознания поступающей молодежи, в том числе, на базе их исторических, правовых знаний, гражданской культуры. Также важны духовные и морально-нравственные начала личности, которые в своём патриотическом выражении неотъемлемы от гражданского сознания молодежи. Высокий уровень сформированности профессионально значимых качеств обучающихся, способствует успешному выполнению ими профессиональных задач, дальнейшему карьерному становлению.

Гражданская идентичность - профессионально значимое качество личности, представляющее собой будущего специалиста, выражающееся в наличии знаний и соблюдений прав и обязанностей граждан, позволяющее эффективно владеть навыками гражданского поведения; отражающее его ценности и активную гражданскую позицию, приобретенное в процессе профессиональной подготовки.

Рассматривая феномен «гражданская идентичность» как профессионально значимое качество специалиста следует уделить внимание ее компонентам.

Исходя из их эталонного для современных исследований определения идентичности как знания о том, что персона принадлежит некоторой социальной группе вместе с эмоциональными и ценностным персональным смыслом группового членства, предложенное Г, Тэджфеллом, гражданскую идентичность можно представить как единство когнитивного, оценочного и ценностно-смыслового компонентов. Кроме того, вслед за отечественными исследователями А.Г. Асмоловым, И. В. Конодой, О.А. Каробановой, А.М. Кондаковым, А.А. Логиновой, в структуре гражданской идентичности личности мы выделяем деятелъностный компонент. Включение деятельностного компонента, на наш взгляд, позволяет преодолеть представление о гражданской идентичности как о своеобразном «мертвом грузе» - принятии гражданского статуса на основе формирования только лишь представления о гражданских правах и обязанностях, «вытекающих» из факта государственной принадлежности[4, с. 255].

Анализ педагогической литературы позволяет сделать вывод о том, что вопрос о формировании гражданской идентичности в процессе профессиональной подготовки будущих специалистов имеет 
большую социально-педагогическую значимость. От его успешного решения во многом будет зависеть выполнение гражданином своих профессиональных обязанностей, реализации своей гражданской позиции, ответственного гражданского поведения.

\title{
Список литературы:
}

1. Административная деятельность органов внутренних дел. Часть особенная: Учебник [Текст] / Анисимова Н.П., Буденко Н.И., Кондрашов Б.П., Коренев А.П., и др.; Под ред.: Коренев А.П. - М.: Щит-М, Изд-во МЮИ МВД России, 1997. - 346 с.

2. Алексеев, С.С. Право: азбука - теория - философия: Опыт комплексного исследования [Текст] / Алексеев, С.С. М., 1999.

3. Алексеев С.С., Яковлев В.Ф. О модели юриста и обучении в юридических вузах // Правоведение. - Л.: Издво Ленингр. Ун-та, 1976, № 4. - С. 73-81.

4. Асмолов, А.Г. Толерантность: от утопии к реальности. На пути к толерантному сознанию [Текст] / А.Г. Асмолов. - М.: Смысл, 2000. - 255 с.

5. Дилигенский, Г.Г. Социально-политическая психология [Текст]/ Дилигиеский Г.Г. Учебное пособие для высших учебных заведений. - М.: Наука, 1994. - 304c.

6. Коваленко, И.А. Педагогические условия развития исследовательской компетентности студентов в образовательном процессе ВУЗа. Дис...канд. пед. наук: 13.00.01. - Благовещенск, 2005. - 24 с.

7. Петровская, Л.А. Теоретические и методические проблемы социально-психологического тренинга. - М.: Из-во Моск.ун-та, 1982. - 168 с.

8. Тазетдинова, Е.Н. Актуальность формирования гражданской идентичности в условиях современного профессионального образования [Текст] // 21 век: фундаментальная наука и технологии. Материалы VI международной научно-практической конференции. Том 1, North Charleston, USA. C.76-79.

\section{РАЗВИТИЕ ИГРОВОЙ ДЕЯТЕЛЬНОСТИ СТАРШИХ ДОШКОЛЬНИКОВ СРЕДСТВАМИ ИНТЕРАКТИВНОГО ТЕАТРА}

\author{
Уиакова Ольга Александровна \\ стариий воспитатель, \\ МБДОУ $\partial / с$ № 45 \\ 2. Белгорода
}

Необходимость развития игровой деятельности у детей в дошкольном возрасте было подтверждено исследованиями еще в начале XX века, в которых раскрывалась роль игры в развитии детей дошкольного возраста (Л.И. Божович, Л.С. Выготский, А.В. Запорожец, А.Н. Леонтьев, Д.Б. Эльконин и др.). В настоящее время подкрепляется текстом Федерального государственного образовательного стандарта дошкольного образования, где игра определяется средством для организации деятельности ребенка, его многогранного развития в социально-коммуникативном, речевом, познавательном, художественно-эстетическом и физическом направлении развития и образования детей [6].

Впервые задачу создания теории детской игры поставил Л.С. Выготский, который рассматривал игру как естественную, стихийно сложившуюся практику поэтапной отработки умственных действий на основе функционального развития игровых действий от развернутых и выполняемых с реальными игрушками и предметами-заместителями к речевым, а затем умственным [1].

По мнению Д.Б. Эльконина, игровая деятельность - это основа социальных взаимоотношений, способствующая разрешению имеющихся противоречий и готовящая ребенка к реализации иных видов деятельности. Как отмечает автор, в игровой деятельности формируются важнейшие личностные стороны участников социума: у дошкольников формируются новые мотивы, устанавливается соподчиненность данных мотивов, происходит формирование механизмов управления собственными поведенческими реакциями, понимание норм этики и моральных устоев окружающих взрослых [8].

На базе муниципального бюджетного дошкольного образовательного учреждения детский сад комбинированного вида № 39 г. Белгорода нами было проведено исследование, направленное на выявление уровня развития игровой деятельности старших дошкольников. В исследовании принимали участие 27 обучающихся старшего дошкольного возраста (старшая группа).

Организовано и проведено наблюдение за игровой деятельностью старших дошкольников в режимных моментах во второй половине дня. Исходя из структуры игры, предложенной Д.Б. Элькониным [8], нами были выделены критерии и показатели сформированности игровой деятельности старших дошкольников (таблица 1). 
ТАБЛИЦА 1

КРИТЕРИИ И ПОКАЗАТЕЛИ СФОРМИРОВАННОСТИ ИГРОВОЙ ДЕЯТЕЛЬНОСТИ

\begin{tabular}{|c|ll|}
\hline Критерии & \multicolumn{2}{|c|}{ Показатели } \\
\hline \multirow{2}{*}{ 1. Замысел игры } & - & умение предложить замысел игры; \\
& - & умение развить замысел по ходу игры; \\
& атрибутов, предметов-заместителей).
\end{tabular}

Нами проанализированы две сюжетно-ролевые игры, организованные детьми: «Автозаправка», «Салон красоты».

По результатам наблюдения за игровой деятельностью старших дошкольников в режимных моментах во вторую половину дня 22,2\% детей имеют высокий уровень, так как им доступно предварительное обдумывание ее замысла в начале игры, выбор темы игры, принятие активного и заинтересованного участия в совместном сюжетосложении, в распределении ролей; они проявляют инициативу и творчество в создании игровой обстановки, учитывая тему игры и мнение партнеров по игре, используя различные атрибуты, предметы-заместители, дополняя игровую обстановку по ходу игры, предлагая для игры сюжеты с использованием мотивов знакомых сказок или нестандартные сюжеты на основе личных впечатлений, т.е. детям присуще творческое сюжетосложение; основным содержанием игры являются действия, связанные с передачей отношения к другим людям, выступающие на фоне всех действий, связанных с выполнением роли; роль, выполняемая детьми, ясно очерчена и выделена; в процессе игры они видят линию поведения, отражающую роль, их игровые действия разнообразны, отражают богатство действий персонажа; ясно выделены игровые действия, которые направлены к разным персонажам игры, они развертываются в последовательности; категорически отвергается нарушение логики действий и правил; речь детей носит активный ролевой характер, определяемый и ролью говорящего, и ролью того, к кому она обращена.

Средний уровень наблюдается у 59,3\% испытуемых, который характеризуется четкой обозначением роли, обсуждением с другими детьми основных направлений развития сюжета, совместный выбор места для игры; дети способны воспроизводить разные по содержанию сюжеты с отражением ряда сюжетных логических эпизодов, содержание игры состоит в выполнении вытекающих из роли игровых действий, у них фиксируется наличие специальных разнообразных действий, которые передают характер отношения к другим участникам игры; выбранная роль определяет поведение в игре; ролевая речь обращена к товарищу по игре в соответствии со своей ролью и ролью, выполняемой товарищем, параллельно присутствует и внеролевая речь - общение с другими детьми не по сюжету игры.

Низкий уровень отмечен у 18,5\% дошкольников, особенности игровой деятельности этих детей отличаются отсутствием подготовительного этапа игры, затруднениями в использовании предметовзаместителей, предпочтением действовать с реальными предметами; центральным содержанием игры являются однообразные действия с определенными предметами без соблюдения соответствия игрового действия реальному; дети воспроизводят элементарные игровые сюжеты, затрудняются самостоятельно придумывать новый вариант сюжета; роль лишь называется и намечается некоторое разделение действий, согласно роли, она реализуется ограниченным количеством действий, связанных с ней; игровые действия отличаются однообразием, состоят из ряда повторяющихся операций, логически не перерастающие в другие за ними следующие действия; легко нарушается логика действий без протестов со стороны детей; отсутствует ролевая речь, присутствуют отдельные внеролевые диалоги с детьми, играющими рядом с ребенком.

На рисунке 1 представлены количественные результаты наблюдения за игровой деятельностью старших дошкольников в режимных моментах во второй половине дня. 


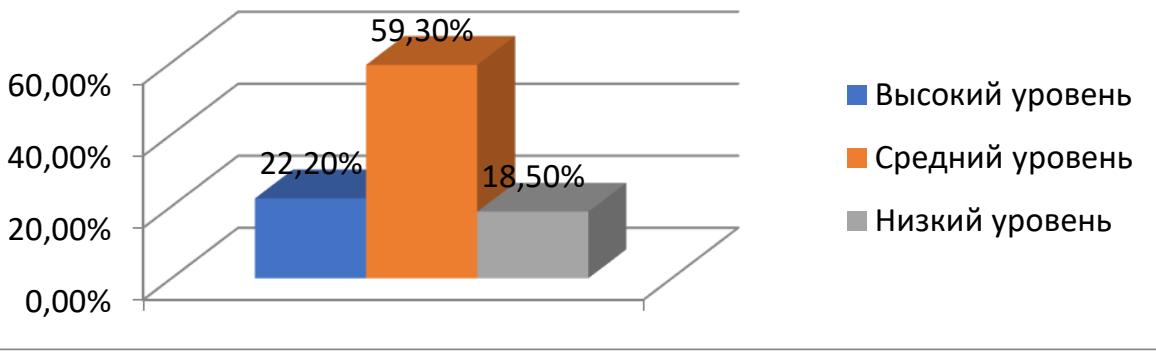

Рисунок 1 Результаты наблюдения за игровой деятельностью стариих дошкольников в режимньх моментах во второй половине дня

Исходя из полученных результатов исследования, может утверждать о недостаточной сформированности игровой деятельностью у детей старшего дошкольного возраста. Что подтверждается также исследованиями Е.О. Смирновой, указывающей на то, что, несмотря на общепризнанные аргументы о ценности игры для развития детей, она подменяется игровыми формами обучения. В режиме дня дошкольных образовательных организаций не остается времени на свободную игру, формирование игры не представляет собой самостоятельную задачу дошкольного образования, более того, игра противопоставляется полезным занятиям как что-то необязательное, а потому ненужное. Следовательно, у современных дошкольников отмечается тенденция снижения показателей развития игровой деятельности. Низкий уровень игры, по данным автора, отмечен у 60\% дошкольников, что, в свою очередь, указывает на актуальность проблемы поиска оптимальных средств, способствующих развитию игровой деятельности детей дошкольного возраста [7].

По мнению ряда исследователей, эффективным средством в образовании являются интерактивные технологии, которые позволяются погрузиться в процесс общения, переживать и осмысливать опыт, применять его на практике.

Интерактивные технологии основаны на взаимодействии ребенка с другими детьми. Такая деятельность позволяет дошкольникам самостоятельно решать сложные проблемы, а не просто быть наблюдателями, создает возможность переноса знаний и опыта деятельности из воображаемой ситуации в реальную, является психологически комфортной и привлекательной. Об этом пишет Г. Аствацатуров: «обучение происходит в форме субъект-субъект» [5, с. 18].

Одним из видов интерактивных технологий является интерактивный театр, который, по мнению Н.В. Григорьянца, представляет собой форму театрального действия, предполагающую активное участие аудитории: зрители перестают быть зрителями и становятся полноправными участниками уже общего творческого процесса. Условия интерактивного театра позволяют зрителю принять активное участие в самом процессе и насладиться происходящим действием изнутри. Ключевая идея интерактивного театра состоит в активном взаимодействии со зрителем, с его внутренним миром [2].

Об интерактивном театре говорит Н.М. Таберко. По его мнению, интерактивный театр предполагает максимальное вовлечение зрителя в театральное действие, где он становится соучастником представления. В отличие от традиционного театра, где зритель почти все время находится в пассивном воспринимающем состоянии, в интерактивном театре зритель активен, вовлечен в ту же деятельность, что и актеры. Однако, это происходит в параллельном зрительском пространстве [3].

Л.Д. Лебедевой установлено, что интерактивный театр непосредственно включает детей в игровое действие, провоцируют их на общение, что способствует возникновению собственно коммуникации. Действие в интерактивном театре выстраивается таким образом, чтобы дети, активно общаясь с персонажами и друг с другом, вовлекались в эмоциональные отношения. Задача интерактивного театра создать условия, способствующие обогащению эмоционального и практического опыта детей, максимально прожить в разных ситуациях, проявить себя в процессе игры. Такой театр содействует спонтанному самовыражению, возникновению вербальной и невербальной коммуникации, изменению стереотипов поведения и повышению адаптационных способностей личности ребенка [4].

В настоящее время отмечается недостаточность методических разработок по использованию интерактивного театра в условиях дошкольного образовательного учреждения. В связи с этим мы обосновали организационно-содержательный аспект по развитию игровой деятельности старших дошкольников средствами интерактивного театра.

Процесс развития игровой деятельности старших дошкольников средствами интерактивного театра будет эффективным, если соблюдать ряд педагогических условий:

- обновление развивающей предметно-пространственной среды Группы дошкольной образовательной организации;

- обеспечение обучающимся позиции субъекта игровой деятельности путем введения роли «режиссера»; 
- повышение уровня педагогической компетентности воспитателей в вопросах организации игровой деятельности детей старшего дошкольного возраста.

Нами разработано календарно-тематическое планирование работы воспитателя по развитию игровой деятельности старших дошкольников средствами интерактивного театра (на примере сюжетно-ролевых игр) (таблица 2).

\section{КАЛЕНДАРНО-ТЕМАТИЧЕСКОЕ ПЛАНИРОВАНИЕ РАБОТЫ ВОСПИТАТЕЛЯ ПО РАЗВИТИЮ ИГРОВОЙ ДЕЯТЕЛЬНОСТИ СТАРШИХ ДОШКОЛЬНИКОВ СРЕДСТВАМИ ИНТЕРАКТИВНОГО ТЕАТРА}

\begin{tabular}{|c|c|c|}
\hline Сроки & Лексическая тема & Сюжетно-ролевая игра \\
\hline Сентябрь & $\begin{array}{c}\text { «Мы снова вместе. } \\
\text { Что изменилось в нашей группе» }\end{array}$ & «Детский сад» \\
\hline \multirow{2}{*}{ Октябрь } & «Дары осени: Откуда хлеб пришел» & «Кафе» \\
\hline & «Страна, в которой я живу» & «МЧС-спасатели» \\
\hline \multirow{2}{*}{ Ноябрь } & «Моя малая Родина» & «Семья» \\
\hline & «День матери» & «Дочки-матери» \\
\hline \multirow[b]{2}{*}{ Декабрь } & «Начало зимы» & «Аптека» \\
\hline & «К нам приходит Новый год» & «Почта» \\
\hline \multirow[t]{2}{*}{ Февраль } & $\begin{array}{c}\text { «Bсе профессии важны, все профессии } \\
\text { нужны» }\end{array}$ & «Магазин» \\
\hline & «Весна пришла» & «Салон красоты» \\
\hline \multirow{3}{*}{ Апрель } & «Юмор в нашей жизни» & Ток-шоу «Аншлаг» \\
\hline & «Первые полеты человека в космос» & «Космодром» \\
\hline & $\begin{array}{c}\text { Права детей в России } \\
\text { «Имею право» }\end{array}$ & «Юристы» \\
\hline
\end{tabular}

Прежде чем организовать работу по развитию игровой деятельности старших дошкольников средствами интерактивного театра, необходима предварительная работа, цель которой заключается в подготовке детей к осуществлению процесса игровой деятельности средствами интерактивного театра. Для этого следует использовать виртуальную экскурсию, а именно видеоэкскурсию, представленную на ютубканале.

Предварительная работа включает в себя три этапа: подготовительный, основной, заключительный. На подготовительном этапе происходит ознакомление с использованием информационно-коммуникационных технологий, но в том числе интерактивных технологий (виртуальная экскурсия). На основном этапе осуществляется организация и реализация процесса моделирования сюжетно-ролевой игры, соответствующей содержанию просмотренному видео. На заключительном этапе происходит рефлексия, т.е. дошкольники комментируют, анализируют и оценивают свои действия.

Для развития игровой деятельности детей старшего дошкольного возраста средствами интерактивного театра можно предложить следующий алгоритм сюжетно-ролевой игры:

1.Определение замысла игры (выбор определенной сюжетно-ролевой игры).

2.Выбор режиссера из группы детей: по желанию; по считалке.

3.Выбор актеров из группы детей: по желанию; по считалке.

4.Определение сюжета игры: самостоятельно режиссером; при совместном обсуждении режиссера с актерами.

5.Распределение ролей между актерами: по желанию детей-актеров; по усмотрению режиссера; по считалке; по вытянутым картинкам героев сказки.

6.Распределение ролевых действий. самостоятельно режиссером; при совместном обсуждении режиссера с актерами.

7.Определение ролевой речи, характерной для конкретной роли.

8.Определение зрителей среди детей.

Остальные дети, не участвующие в игре являются зрителями.

Следует отметить, что после организованной игры предыдущими детьми возможно перераспределение ролей между детьми группы, т.е. зрители могут стать также режиссером или актерами.

9.Определение пространственного расположения режиссера, актеров и зрителей - режиссером.

10.Непосредственно сюжетно-ролевая игра.

Создание предметно-пространственной среды, способствующей развитию игровой деятельности детей через интерактивный театр, подразумевает:

- создание и подбор декораций в соответствии с сюжетом;

- создание и подбор атрибутов и их заместителей в соответствии с сюжетом;

- создание и подбор костюмов для героев в соответствии с сюжетом и выполняемой ролью. 
Для повышения уровня педагогической компетентности воспитателей в вопросах организации игровой деятельности детей старшего дошкольного возраста рекомендуется использовать следующие формы работы:

- педагогический ринг «Пути совершенствования образовательного процесса в условиях современного ДОУ». Цель: ориентировать воспитателей на изучение новейших исследований в педагогике, методической литературе, способствовать выявлению различных подходов к решению педагогических задач;

- мастер класс «Играем вместе с детьми». Цель: обобщить представления воспитателей об организации игровой деятельности дошкольников;

- семинар-практикум «Интерактивный театр в образовательном процессе ДОУ». Цель: обогатить представления воспитателей о проблеме использования интерактивного театра в образовательном процессе дошкольного учреждения;

- деловая игра «Развитие игровой деятельности детей посредством интерактивного театра». Цель: обогатить представления воспитателей об особенностях использования интерактивного театра как средства развития игровой деятельности дошкольников;

- банк идей «Как вернуть в жизнь современного ребенка игровую деятельность?». Цель: учить воспитателей искать рациональные способы коллективного решения проблем, не поддающихся решению традиционными способами.

Таким образом, организация работы по развитию игровой деятельности старших дошкольников средствами интерактивного театра требует грамотного подхода со стороны педагога, необходима система работы, определяющая конкретное содержание работы воспитателя в данном направлении.

\section{Список литературы}

1.Выготский Л.С. Игра и ее роль в психическом развитии ребенка // Психология развития. - СПб: Питер, 2001. -512 c.

2.Григорьянц Н.В. Театральный интерактив как модель коммуникации современной культуры // Вестник Томского государственного университета. 2014. - № 383. - С. 73-77.

3.Интерактивное театральное представление для молодежи: Методическое пособие по формированию ответственного поведения в ситуации риска / Таберко Н.М. - Минск: 2008. - 60 с.

4.Лебедева Л.Д. Практика арт-терапии: подходы, диагностика, система занятий / Л.Д. Лебедева. - СПб: Речь, 2008. - 256 с.

5.Педагогика: учеб. пособие для бакалавров / под ред. П. И. Пидкасистого. - 3-е изд., испр. и доп. - М.: Юрайт, 2013. - 511 с.

6.Приказ Министерства образования и науки Российской Федерации от 17 октября 2013 г. № 1155 «Об утверждении федерального государственного образовательного стандарта дошкольного образования»

7.Смирнова Е.О. Психология и педагогика игры учебник и практикум для академического бакалавриата / Е.О. Смирнова, И.А. Рябкова. - М.: Издательство Юрайт, 2019. - 223 с.

8.Эльконин Д.Б. Психология игры. - М.: Книга по Требованию, 2013. - 228 с. 


\title{
ПОЛИТИЧЕСКИЕ НАУКИ
}

\section{ВОЙНА - ПРОДОЛЖЕНИЕ ПОЛИТИКИ, В ТОМ ЧИСЛЕ ЖЕНСКИМИ РУКАМИ}

\author{
Саенко Павел Андреевич \\ К.ф.н.,доцент УрГЮУ \\ Екатеринбург \\ Шабуров Анатолий Степанович \\ Д.ю.н.,профессор УрГЮУ \\ Екатеринбург
}

История общества представляет собой череду бесчисленных войн, насилия, порабощения и взаимного уничтожения. Хотя если поставить вопрос так: что предпочтительнее человеколюбие, уважение к личности или человеконенавистничество, стремление подавить личность вплоть до её уничтожения, то абсолютное большинство нормальных людей выберут первый вариант ответа.

Однако по подсчетам военных историков с 3600 г. до н.э. по настоящее время (т.е. более, чем за 5,5 тыс. лет) на Земле было только 300 мирных лет, но 15000 войн, которые унесли 3,5 млрд. человеческих жизней [3,c.64-67]. Прямыми жертвами войн в Европе среди военных стали:

- в 17 в. Более 3 млн. человек;

- в 18 в. Более 5 млн. человек;

- с 1800 по 1815 гг. погибло более 3,6 млн. человек (эпоха наполеоновских войн);

- с 1815 по 1914 гг. погибло более 2,2 млн. человек.

Если в первой мировой войне погибли 9,5 млн. военнослужащих, то во второй мировой войне этот показатель вырос до 27 млн. (с учетом потерь гражданского населения - более 55 млн.). С 1900 по 1980 гг. в мире произошло 154 войны, в ходе которых погибло более 100 млн. человек [6,с.57-60].

Таким образом, войны на планете Земля постоянно сопровождают человечество. Более того, прослеживается явно выраженная тенденция роста их масштабов, вовлечения всё большего количества стран, всё больше в войнах гибнет людей. Войны перестают быть чисто «мужским делом», для участия в них всё в большей степени привлекаются и женщины. Это матери, жены, дочери, которые самой природой предопределены продлять род человеческий. Можно привести такие данные: если в Отечественной войне 1812 года участие женщин носило эпизодический характер, и скорее было исключением из правил, то во всех последующих актах военного насилия картина изменилась. Например, если в первой мировой войне участвовало около 2000 женщин, - во второй мировой войне - уже 800000 (речь идёт о призванных в российскую - советскую армии, и о добровольцах). Сегодня в Российской армии в отдельных родах войск, в отдельных частях численность женщин среди военнослужащих приближается к 50,0\%.

Нельзя не сказать о существующем в сознании значительной части граждан заблуждении, которые полагают, что если женщин в политике будет больше, то и с войнами мы вскоре покончим. На слуху сегодня имена таких американских дам в политике, как Мадлен Олбрайт и Хилари Клинтон. Очень трудно их представить с оливковой ветвью мира в руках, скорее им подошли бы рыцарские доспехи. В своё время Маргарет Тэтчер, будучи премьер министром Великобритании инициировала начало военных действий против Аргентины для решения в свою пользу вопроса о Фолклендских островах, возле которых обнаружились запасы нефти.

Во второй половине XVIII века Елизавета Петровна, дочь Петра Великого, послушав совета канцлера Бестужева-Рюмина, а также в силу личной неприязни к королю Пруссии Фридриху приняла участие в семилетней войне на стороне анти прусской коалиции. Екатерина II, как нормальная императрица, тоже в случае необходимости разрешала возникшие межгосударственные проблемы посредством вооруженного насилия. Только одних эмоций для этого по её мнению недостаточно. Она писала: «Я довольно воинственна, но никогда не начну войну без причины, если же сделаю это, то не так как императрица Елизавета, из угождения другим, а лишь тогда, когда найду это удобным для себя [5,c.19]».

Война - это форма социального насилия, которая представляет собой организованную вооруженную борьбу между государствами (их союзами) в целях удовлетворения политических, экономических, идеологических (в том числе религиозных) интересов государства, определенных классов, социальных групп.

По своей сути война представляет собой продолжение политики именно насильственными средствами [2,c.151,355]. В зависимости от политики, которая в войне продолжается, она может быть как прогрессивной, так и реакционной.

Проблема участия женщин в войне не может не привлекать внимание ученых, исследователей, обществоведов. В историографии данного социального феномена, занимающего важное место в истории России XX века, можно выделить два периода:

- советский период - с 1941 до конца 80-х годов;

- постсоветский период - с начала 90-х годов по настоящее время. 
К наиболее заметным работам первого периода можно отнести содержательный труд Н.А. Вознесенского и шести томную «Историю Великой Отечественной войны Советского народа 1941-1945 гг.». А также первую комплексную монографию, посвященную проблеме трудового и боевого подвига женщин страны Советов В.С. Мурманцева.

К этому же периоду относится появление работ, отражающих данную проблему на региональном уровне. Применительно к Уралу это, прежде всего, работы, повествующие об Уральском Добровольческом танковом корпусе, Московской зоне ПВО, девушках, воевавших на Балтике [4].

К работам второго периода можно отнести диссертационные исследования А.А. Вдовиной, Е.Ю. Волковой. Региональный аспект - участие уральских женщин в Великой Отечественной войне, - отражен в работах известных уральских историков В.П. Мотревича, Г.Е. Корнилова, А.В. Фёдоровой и других [7,с.205]. Определённый интерес представляет работа Е.С. Станиславской, опубликованная в пятом номере журнала «Мир истории» за 2000 год.

Согласно существующих, законов женщины не подлежали призыву на военную службу в годы Великой Отечественной войны. Тем не менее, они воевали. Призывали тех, кто получил специальности медицинского профиля, связи и некоторые другие. Например, специальности связанные с работой на железнодорожном транспорте. Девушек призывали в войска ПВО, прикрывавшие Московскую зону. На фронт призывали девушек и по комсомольскому набору (т.о. через районные комитеты комсомола).

Женщина с оружием в руках - явление неординарное, противоречащее её жизненному предназначению. И, тем не менее, большинство из оказавшихся на фронте сделали это сознательно, ибо они сознательно стремились защищать свою Родину. В качестве примера можно привести дневниковую запись лётчицы Галины Докупович от 27 мая 1943 года: «Помню 10 октября 1941 года, Москва. В этот день в ЦК ВЛКСМ было особенно шумно и многолюдно. И, главное, здесь были почти одни девушки. Пришли они со всех концов столицы - из институтов, с учреждений, с заводов. Девушки были разные - задорные, шумные и спокойные, сдержанные; коротко стриженные и с длинными косами; механики, парашютисты, пилоты и просто комсомолки, никогда не знавшие авиации. Они по очереди заходили в комнату, где за столом сидел человек в защитной гимнастёрке. «Твердо решили идти на фронт?» «Да!» «А вас не смущает, что трудно будет?» «Нет! [1]».

Одна из основных причин, объясняющих готовность женщин идти на фронт, в боевые части состояла в том, что молодое поколение страны Советов воспитывалось в духе патриотизма. Этому способствовали и школа, и комсомол, и книги, и фильмы, и весь уклад жизни. Прежде думай о Родине, а потом о себе - это был не просто крылатый лозунг, а девиз, которому следовала в жизни значительная часть юношей и девушек.

Другая причина состояла, как это ни покажется странным, в определённой степени эмансипации женщин, наступившей в стране после революции. Это было связано с тем, что после революции политика советского государства в женском вопросе, направленная на вовлечение женщин в общественное производство, способствовала быстрому развитию эмансипации со всеми её последствиями. В результате участие женщин в наиболее тяжёлом физическом труде, приобщение их к традиционно "мужским" профессиям, к занятиям военно-прикладными видами спорта преподносилось общественному мнению как величайшее достижение социализма, проявление подлинного "равенства полов" и освобождение женщины от "домашнего рабства". Идеи эмансипации были наиболее популярны в молодёжной среде. А комсомольские призывы, наборы и мобилизации под лозунгами "Девушки - на трактор!", "Девушки - в авиацию!", "Девушки - на комсомольскую стройку!" и т.д. явились своего рода психологической подготовкой к массовому участию советских женщин в грядущей войне, которая вошла в историю нашей страны как Великая Отечественная. С её началом сотни тысяч женщин устремились в армию, не желая отставать от мужчин, чувствуя, что способны наравне с ними вынести все тяготы воинской службы, а главное - утверждая за собой равные с ними права на защиту Родины. Только в части ПВО было призвано 300000 женщин.

Глубокий патриотизм поколения, воспитанного на героических символах недавнего революционного прошлого, но имевшего в большинстве своём книжно-романтические представления о войне, отличал и тех 17-18-летних девочек, которые осаждали военкоматы с требованием немедленно отправить их на фронт. Они были готовы к подвигу, но не были готовы к армии, и то, с чем им пришлось столкнуться на войне, оказалось для них неожиданностью. Гражданскому человеку всегда трудно перестроиться "на военный лад", женщине - особенно. Армейская дисциплина, солдатская форма на много размеров больше, мужское окружение, тяжёлые физические нагрузки - всё это явилось нелёгким испытанием. Но это была именно та "будничная вещественность войны, о которой они, когда просились на фронт, не подозревали". Потом был и сам фронт - со смертью и кровью, с ежеминутной опасностью и "вечно преследующим, но скрываемым страхом". Потом, спустя годы, те, кто выжил, признаются: "Когда посмотришь на войну нашими, бабьими глазами, так она страшнее страшного". Потом они сами будут удивляться тому, что смогли всё это выдержать. И послевоенная психологическая реабилитация у женщин будет проходить сложнее, чем у мужчин: слишком велики для женской психики подобные эмоциональные нагрузки.

Феномен участия женщины в войне сложен уже в силу особенностей женской психологии, а значит, и восприятия ею фронтовой действительности. "Женская память охватывает тот материк человеческих чувств 
на войне, который обычно ускользает от мужского внимания, - подчёркивает автор книги "У войны - не женское лицо..." Светлана Алексиевич. - Если мужчину война захватывала, как действие, то женщина чувствовала и переносила её иначе в силу своей женской психологии: бомбёжка, смерть, страдание - для неё ещё не вся война. Женщина сильнее ощущала, опять-таки в силу своих психологических и физиологических особенностей, перегрузки войны - физические и моральные, она труднее переносила "мужской" быт войны". В сущности, то, что пришлось увидеть, пережить и делать на войне женщине, было чудовищным противоречием её женскому естеству.

Другая сторона феномена - неоднозначное отношение военного мужского большинства, да и общественного мнения в целом к присутствию женщины в боевой обстановке, в армии вообще. Самой природой заложена в женщине функция материнства, продолжения человеческого рода. Женщина даёт жизнь Тем противоестественнее кажется словосочетание "женщина-солдат".

В период Великой Отечественной в армии служило сотни тысяч женщин, а просилось на фронт ещё больше. Не все они оказались на передовой: кто-то попал во вспомогательные подразделения и службы, в которых требовалось заменить ушедших на фронт мужчин. Были и службы "чисто женские", как, например, в баннопрачечных отрядах. Наше сознание спокойно воспринимает женщину-телефонистку, радистку, шифровальщицу, врача или медсестру, повара или пекаря, шофёра и регулировщицу - то есть те профессии, которые не связаны с необходимостью убивать. Но женщина-лётчик, снайпер, стрелок, автоматчик, зенитчица, танкист и кавалерист, матрос и десантница - это уже нечто иное. Жестокая необходимость толкнула её на этот шаг, желание самой защищать Отечество от беспощадного врага, обрушившегося на её землю, её дом, её детей.

За заслуги в борьбе с немецко-фашистскими захватчиками в годы Великой Отечественной войны свыше 150 тыс. женщин были награждены боевыми орденами и медалями. 93 удостоены звания Героя Советского Союза. Четверо стали полными кавалерами ордена Славы. И одна из них наша землячка из Туринска. Это Надежда Журкина (Киёк). Воздушный стрелок-радист, она совершила 87 боевых вылетов, участвовала в 30-ти боях. Демобилизовалась в августе 1945. До распада Советского Союза жила в Риге, работала начальником отдела кадров на заводе «Ригас айгербс». А когда Советский Союз распался, и жить русским в Латвии стало очень не просто, она обратилась с письмом в адрес вице-президента России Руцкого и попросила о помощи. За заслуженным ветераном Москва послала самолёт. Погрузили книги, фотографии, личные вещи. С этим набором и поместили Журкину на проживание в пансионате. Здесь она и скончалась 24 апреля 2002 года. Похоронили героиню, образно говоря, повторившую подвиг Надежды Дуровой, которая в годы первой мировой стала полным Георгиевским кавалером, на Николо-Архангельском кладбище.

И всё же абсолютное большинство воевавших на фронтах Великой Отечественной войны женщин имели обычные судьбы. Воевали, терпели бедствия и лишения, теряли боевых друзей. И наград им лишних никто не давал. Об одной такой судьбе и пойдёт речь.

1941-1942 годы - самый тяжелый начальный период войны. Стратегическая инициатива на стороне фашистов, они продолжают наступление. Фронту нужны новые пополнения. Труднее всего на сухопутье. И тогда принимается решение: часть старшин и матросов с кораблей и из частей военно-морского флота отправить на сухопутный фронт. В связи с этим с августа 1942 года начала работать Соловецкая школа юнг, которая готовила специалистов для кораблей флота. И в том же году начался призыв девушек в береговые части ВМФ. Им довелось воевать не только в качестве медперсонала, но и радистками, телефонистками, шифровальщиками, водителями и т.п.

Многие девушки с Урала воевали на Балтике. Вот одна из обычных военных судеб. Тася Воротникова родилась в Далматовском районе Курганской области. В 1939 году она окончила Камышловское педучилище и получила направление в город Артемовск. Заведующий районным отделом народного образования Ишаев принял тепло, расспросил, откуда родом, как училась. А затем поставил условие: если Воротникова согласится 1 год отработать в начальной школе совхоза им. Орджоникидзе, то уже на следующий год она может выбрать любую другую школу. На том и договорились.

В совхозе было четыре класса по 5-6 человек в каждом. 2 из них учились в первую смену, 2 других - во вторую. А учитель, естественно, один. Год пролетел незаметно. Запомнилась одна интересная деталь: так как в школе часов не было, Таисия Андреевна ежедневно снимала со стены комнаты где жила ходики, и, взяв их под мышку, шагала на работу.

Наступил 1940-й год. Воротникова выбрала для дальнейшей работы школу №1 города Артемовска. Основание было веским: рядом со школой жила давнишняя подруга Шура Никулина, с которой они вместе учились в школе. Она к тому времени вышла замуж и переехала из Далматовского района в Артемовск. Работала, учила грамоте призывников, которым не довелось обучаться в школе.

Директором в первой школе был Дмитрий Ефимович Шипов. Он дал молодой учительнице 3-й класс, так как работавшего с ним педагога призвали в армию. Работа с детьми Таисье Андреевне нравилась и она, засучив рукава, принялась за дело в новом педагогическом коллективе. К 1942 году она спортсменка, участница художественной самодеятельности, секретарь комсомольской организации школы. Воротникову ставят в пример, её класс один из лучших в школе. В августе до начала занятий учителя работали на уборке 
картошки в пригородном колхозе. Отработали уже две недели, как в один из дней к ним прямо в поле подъехал всадник на лошади, как оказалось, курьер из военкомата. Он спросил: «кто здесь Воротникова?». Самая маленькая из всех учителей (ростом в 1 м 53 см) Тася вышла вперед и сказала - «Я». После чего ей была вручена повестка в военкомат, где значилось, что ей надлежит к 10.00 следующего дня быть с вещами в военкомате. Она, как и положено, доработала до конца дня. Вечером вернулась в свою комнату и стала складываться на фронт. Дома, в селе Широково оставались мама, две сестры и брат. Еще одна сестра работала в Боровлянской школе Пышминского района. Хотелось с ними попрощаться, но времени на это уже не было. А старший брат - Павел был офицером, танкистом и воевал второй год.

В военкомате их собралось 25 девушек - секретарей комсомольских организаций со всего района. В товарном вагоне всех их отправили на Запад, на Балтийский флот. Так началась Тасина военная судьба. Ехали долго. Покормили только один раз, в Кирове. Спали прямо на полу, не было ни матрасов, ни даже соломы. В Вологде эшелон бомбили фашисты. Пришлось девушкам бежать в ближайший лесок. Затем была Ладога, шли на катере, опять бомбили, но дошли без потерь.

Переночевали в каких-то казармах в Ленинграде, далее опять на корабле в Кронштадт, в школу связи им. А.С. Попова. Блокаду Тася переживала вместе со всеми, а еще осваивала профессию радиста и ходила в караулы на лед Финского залива. В январе 1943 вместе со всеми радовалась прорыву блокады Ленинграда. Однажды девушки - курсанты как всегда после занятий строем возвращались в казарму. Началась бомбежка. Рядом со строем разорвалась бомба. Тасю контузило, царапнуло ногу. Боевые подруги на руках отнесли раненую в казарму. Пришел врач, осмотрел: руки и ноги целы, а контузия пройдет. Голову и ногу перебинтовали, от занятий освободили. Долечиваться пришлось прямо в казарме.

Вскоре экзамены подошли. Так хотелось их сдать вместе со всеми, что решение пришло само собой: через окно на камбузе вылезала и шла в матросский клуб за своей оценкой, благо он недалеко от школы связи располагался. И так 10 дней, 10 экзаменов. Патрули встречались и не трогали: идет себе девушкаматрос с палочкой, с перебинтованными головой и ногой, значит так и надо. Все экзамены Воротникова сдала на «отлично», кроме приема на слух - бинты помешали, поэтому только «хорошо».

Смену радистов назначили на знаменитый остров Лавенсари ныне остров Мощный) - наш передовой рубеж в Финском заливе. Караван на остров пошел большой - вымпелов тридцать. Естественно, там были и транспорта, и корабли охраны, и катера - дымзавесчики. Самолеты противника пока еще господствовали в небе. Первый выход оказался неудачным. Начался сильный обстрел и караван вернулся в гавань. Пошли во второй раз. Девушки запели «Прощай любимый город». Судьба оказалась на сей раз милостивой, и караван дошел без потерь.

На Лавенсари были частые артобстрелы, бомбежки. С одного берега стрельбу вели пушки немцев, а с другого - финнов. Даже «Толстую Берту» (мортиру калибром 420 мм) фашисты доставили из Крыма, так мешал им этот остров. Здесь же они испытывали многие новые виды оружия. Например, подпрыгивающие мины, которые взрывались на некоторой высоте над землей. Однажды бомба фашистов угодила в артиллерийский склад, над островом заполыхало зарево, долго рвались боеприпасы, а осколки разлетались вокруг. И в то же время это был форпост Балтийского флота, здесь была удобная гавань, в которой стояли и надводные и корабли и подводные лодки. На аэродроме базировался истребительный авиаполк и масса береговых частей.

Воротникову назначили служить в артиллерийский дивизион. Вначале ей доверили нести вахты на деревянной вышке СНИС (служба наблюдения и связи) откуда она должна была по рации сообщать о подлетающих самолетах противника. Под обстрелами вышка шаталась, было страшно, но все равно вахту нести надо. Старшина батареи мичман Павлов, всякий раз встречая ее после очередной вахты на земле, спрашивал: «Жива?» и она отвечала: «Жива». А дальше бежала с рацией в землянку. Однажды в вышку попала бомба, хорошо, что в этот момент на ней никого не было. После этого случая Воротникова несла радиовахты в артиллерийском дивизионе, которым командовал капитан Павел Афанасьевич Романов. Здесь же на батарее служила Саша Муравьева из Нижнего Тагила. Она была телефонистка. Подружки вместе вспоминали родной Урал, строили планы на гражданскую жизнь. Вместе на остров Гогланд высаживались. Далее их дороги разошлись: Шура осталась на острове, а Тасе со своим дивизионом довелось освобождать Эстонию.

Был и такой случай: во время боя сбило антенну. Рассуждать некогда. Скинула радистка сапоги, юбку и залезла на дерево. Связь восстановила. Надо спускаться назад, но достаточно высоко, страшно. А внизу командир батареи капитан Кузьменко подает команду: «Добирайся до нижней ветки и прыгай, я поймаю!». А девушке еще и стеснительно - как никак без юбки перед командиром на дереве сидит. Тут рядом снаряд разорвался. С дерева радистку сбросило взрывной волной достаточно удачно, все обошлось лишь ушибами да царапинами.

Далее был остров Малый Роге, затем город Палдиски. Вскоре и демобилизация подоспела. Здесь в Эстонии Тася и жить осталась после войны. Вышла замуж за своего фронтового друга, с которым вместе еще на Лавенсари воевали. Двоих сыновей вместе вырастили. Они тоже свою жизнь с флотом связали. Теперь она вернулась на родину, живет в Екатеринбурге.

В заключение уместно привести следующие слова Константина Симонова: "Мы, говоря о мужчинах на войне, привыкли всё-таки, беря в соображение все обстоятельства, главным считать, однако, то, как воюет 
этот человек. О женщинах на войне почему-то иногда начинают рассуждения совсем с другого. Не думаю, чтобы это было правильно". Бывшие солдаты с благодарностью вспоминают своих подружек, сестрёнок, которые выволакивали их раненых с поля боя, выхаживали в медсанбатах и госпиталях, сражались с ними рядом в одном строю. Женщина-друг, соратник, боевой товарищ, делившая все тяготы войны наравне с мужчинами, воспринималась ими с подлинным уважением. К сожалению, наблюдается всё большее участие женщин в войнах, и их руками тоже продолжается политика в этих, сопровождающих общественное развитие трагических событиях.

\section{Список литературы.}

1. Белорусский государственный музей истории Великой Отечественной войны. Инв. 36792.

2. Военный энциклопедический словарь. М., 1983. С.151,355.

3. Золотарев В.А., Тюшкевич С.А. Опыт и уроки отечественной военной истории. М., 1995. С.64-67.

4. Кодочигов Павел. «Как ты жива осталась мама». Екатеринбург, 1979.

5. Мартынов В.И. Политика и стратегия. М., 2003.С.19. 3.

6. Милитаризм: цифры и факты. М., 1983. С.57-60.

7. Федько А.В. Ратный подвиг уральских женщин на полях сражений. Уфа, 2005. 


\section{ПСИХОЛОГИЧЕСКИЕ НАУКИ}

\section{СТРАТЕГИИ ПРЕОДОЛЕНИЯ СТРЕССА С УЧЁТОМ ТЕМПЕРАМЕНТА РАБОТНИКА}

Труикова Светлана Викторовна

кандидат психологических наук,

доиент

Московского автомобильно-дорожного государственного технического университета

(МАДИ),

Москва

Калашникова Дарья Дмитриевна

студентка факультета управления

Московского автомобильно-дорожного государственного технического университета

(МАДИ),

Москва

Трудовая деятельность современного работника в большинстве случаев представляет собой непрерывный и напряженный процесс, сопровождаемый состоянием стресса, которое, в свою очередь, вызвано перенасыщением информацией, неблагоприятной экологией, переизбытком общения, разного рода сложными жизненными ситуациями и другими факторами, вызывающими кризисы, ухудшение здоровья работников, а также снижающими его способность к эффективному выполнению трудовых функций и провоцирующие наступление профессиональной деформации и профессионального выгорания работников. Ввиду повышения уровня стресса у современного работника и его неблагоприятных последствий (в том числе и для всей организации) приобретает особую актуальность рассмотрение теоретических оснований факторов, влияющих на формирование стресса, с последующей прикладной разработкой подходов к снижению и преодолению стресса. Одним из важных стрессообразующих факторов является способ реагирования на события окружающей жизни, обусловленный психофизиологическими особенностями человека, т.е. его темпераментом.

Необходимость преодоления стресса обосновал еще Ганс Селье [5], подразумевая, что устранять необходимо лишь негативное воздействие стимулов, то есть дистресс. Таким образом, целесообразно говорить о совокупности способов борьбы со стрессом, именуемой в психологии копингом или копингстратегиями. При дословном переводе с английского (соре, coping - совладать, справляться) данный термин можно раскрыть как совокупность способов преодоления человеком стресса, выхода из неблагоприятного состояния и защиту от воздействия стресс-фактора. Несмотря на то, что столь актуальный вопрос имеет насыщенную ретроспективу, не существует единого подхода к определению понятия и видов копинг-стратегий в научной литературе. Среди зарубежных исследователей следует выделить Л. Мерфи, который впервые употребил данный термин для обоснования применяемых детьми способов преодоления требований, выдвигаемых кризисами развития [7].

Исследование понятия копинга и его видов также связано с такими представителями зарубежной психологии, как Р. Лазарус и С. Фолькман. Изначально Р. Лазарус применял ситуативный подход к объяснению данного феномена, предполагая, что стратегии, ориентированные на ситуацию, вызвавшую стресс (проблемно-ориентированные стратегии) более эффективны в ситуациях, поддающихся контролю. В случае затрудненного или воспринимаемого как недостижимого контроля чаще будут использоваться эмоционально-ориентированные стратегии. Исследования подтвердили эту гипотезу с той поправкой, что наиболее эффективной «эмоциональной» стратегией является принятие. Впоследствии в соавторстве Р. Лазарус и С. Фолькман разработали подход к копингу как к динамическому процессу, специфика которого определяется не только ситуацией, но и переживаниями самого субъекта, а также его столкновением с внешним миром [10,11]. На основании проведенных исследований учеными были предложены активная и пассивная форма копинг-стратегий. Первая форма предполагает интенсивное противодействие стрессу и целенаправленное устранение вызывающей его ситуации. Вторая (пассивная) форма представляет собой построение подходящей психологической защиты, призванной снижать эмоциональное возбуждение, но при этом не устраняет саму проблему.

Другим известным подходом к классификации совладеющих стратегий является подход Дж. Амирхана [9], сформированный на основании анализа поведенческих ответов на стресс. Данный подход предусматривает три группы стратегий: стратегии разрешения проблемы, стратегии поиска социальной поддержки и стратегии избегания (таблица 1). 


\begin{tabular}{|l|l|}
\hline \multicolumn{1}{|c|}{ Копинг-стратегии } & \multicolumn{1}{|c|}{ Описание } \\
\hline \multicolumn{1}{|c|}{$\mathbf{1}$} & \multicolumn{1}{|c|}{$\mathbf{|}$} \\
\hline $\begin{array}{l}\text { Стратегия разрешения } \\
\text { проблемы }\end{array}$ & $\begin{array}{l}\text { Активная поведенческая стратегия, при которой человек старается } \\
\text { использовать все имеющиеся у него личностные ресурсы для поиска } \\
\text { возможных способов эффективного разрешения проблемы. }\end{array}$ \\
\hline $\begin{array}{l}\text { Стратегия поиска } \\
\text { социальной поддержки }\end{array}$ & $\begin{array}{l}\text { Активная поведенческая стратегия, при которой человек для } \\
\text { эффективного разрешения проблемы обращается за помощью и } \\
\text { поддержкой кокружающей его среде. }\end{array}$ \\
\hline Стратегия избегания & $\begin{array}{l}\text { Поведенческая стратегия, при которой человек старается избежать } \\
\text { контакта с окружающей его действительностью, уйти от решения } \\
\text { проблем. }\end{array}$ \\
\hline
\end{tabular}

Примером стратегии разрешения проблемы может служить скрупулёзное изучение экзаменационных билетов студентом, нежелающим получит двойку на экзамене. Стратегии поиска социальной поддержки используются человеком при обращении за помощью к близким и друзьям или экспертам. Примером стратегии избегания является отрешение от проблемы, переключение на хобби или отдых, в то время как необходимо сосредоточить все внимание на решении проблемы, вызывающей стресс. Стоит отметить, что как правило, человек применяет не одну, а несколько копинг-стратегий разных видов в зависимости от ситуации. Кроме того, стратегии избегания не всегда являются неэффективными, так как в ряде случаев активные действия могут усугубить положение, а помощь привлеченных к решению проблемы лиц не принесёт должного результата, либо также негативно повлияет на ситуацию.

Э. Хайм совладающие стратегии классифицирует по сферам психической деятельности человека: когнитивные, эмоциональные и поведенческие. Когнитивные стратегии - это мыслительные акты, связанные с решением проблемы, вызывающей стресс, либо уход от нее. Эмоциональные стратегии представляют собой проявление положительных или отрицательных эмоций в момент стресса или их отсутствие. Поведенческие стратегии представляют собой действия и различные поведенческие акты, которые реализует человек в состоянии стресса. Когнитивные, эмоциональные и поведенческие стратегии, с свою очередь, делятся по степени продуктивности: продуктивные, относительно-продуктивные и непродуктивные стратегии. К первому виду относятся стратегии, применяя которые человек эффективно справляется со стрессом. Относительно-продуктивные являются стратегии, которые помогают только в определенных случаях, либо же применяются индивидуально. К непродуктивным относятся стратегии, которые не помогают побороть стресс, а лишь усугубляют его (таблица 2).

\section{НАПРАВЛЕНИЕ И ПРОДУКТИВНОСТЬ КОПИНГ-СТРАТЕГИЙ}

\begin{tabular}{|c|c|c|}
\hline $\begin{array}{l}\text { Стратегии по } \\
\text { направлению }\end{array}$ & $\begin{array}{c}\text { Стратегии по } \\
\text { продуктивности }\end{array}$ & Описание \\
\hline \multirow{3}{*}{$\begin{array}{l}\text { Когнитивные } \\
\text { стратегии }\end{array}$} & Продуктивные & Анализ проблемы \\
\hline & $\begin{array}{l}\text { Относительно- } \\
\text { продуктивные }\end{array}$ & $\begin{array}{l}\text { Сравнение своей проблемы с проблемами других, } \\
\text { игнорирование, сознательное скрывание проблемы } \\
\text { или ее преуменьшение. }\end{array}$ \\
\hline & Непродуктивные & Растерянность, смирение. \\
\hline \multirow{3}{*}{$\begin{array}{c}\text { Эмоциональные } \\
\text { стратегии }\end{array}$} & Продуктивные & Оптимизм \\
\hline & $\begin{array}{l}\text { Относительно- } \\
\text { продуктивные }\end{array}$ & $\begin{array}{l}\text { Пассивная кооперация (человек доверяет решение } \\
\text { проблемы другим), протест. }\end{array}$ \\
\hline & Непродуктивные & $\begin{array}{l}\text { «Выплеск эмоций» (эмоциональная разрядка), } \\
\text { агрессивность, самообвинение. }\end{array}$ \\
\hline \multirow{3}{*}{$\begin{array}{c}\text { Поведенческие } \\
\text { стратегии }\end{array}$} & Продуктивные & Сотрудничество \\
\hline & $\begin{array}{l}\text { Относительно- } \\
\text { продуктивные }\end{array}$ & $\begin{array}{l}\text { Переключение на хобби или работу, на проблемы } \\
\text { других людей, получение совета от других. }\end{array}$ \\
\hline & Непродуктивные & $\begin{array}{l}\text { Активное отступление, самоизоляция от других } \\
\text { людей }\end{array}$ \\
\hline
\end{tabular}

Находясь в состоянии стресса, человек применяет не одну, а комплекс копинг-стратегий. Если придерживаться подхода Э. Хайма, то ключевое значение будет иметь состояние, в котором находится 
человек, а также продуктивность применяемых стратегий, т.е. насколько применяемый комплекс стратегий помогает преодолеть негативное воздействие стрессора.

Современные психологи в ряде случаев рассматривают копинг-стратегии в совокупности со стратегиями эмоционального регулирования, а также стремятся определить факторы, влияющие на выбор стратегии. Так в Aldwin C.M., Sutton K.J., Lachman M. Провели исследование зависимости копинг-стратегий и эмоционального регулирования от возраста, пола и уровня образования. На данный момент, ссылаясь на результаты этого исследования, можно сказать, что уровень образования играет важную роль относительно выбора и использования копинг-стратегий и эмоционального регулирования. Выявлено, что люди с низким уровнем образования используют менее эффективные стратегии по сравнению с испытуемыми

высоким уровнем образования. При этом копинг-стратегии и эмоциональное регулирование рассматриваются как отдельные понятия [8].

Одним из актуальных направлений в современных психологических исследованиях копинг-стратегий является изучение копинг-ресурсов. Стоит отметить, что данное направление сформировалось относительно недавно, его развитие в зарубежной психологии началось раньше, чем в отечественной и также, как и в случае с копинг-стратегиями, не было сформулировано единого подхода к определению и классификации. Психологи Калифорнийского университета в Лос-Анджелесе выделили следующие копинг-ресурсы: социальная поддержка, оптимизм, самооценка. Первый копинг-ресурс - социальная поддержка определяется как альтруизм, умение человека ценить и уважать окружающих его людей, их интересы и ценности, а также построение благоприятных отношений на основе взаимопомощи. Должное развитие данного копинг-ресурса уменьшает риск депрессии и повышенной тревоги, а также способствует успешной адаптации к состоянию стресса. Под оптимизмом понимается ожидание положительного результата развития ситуации и выполняемой деятельности. При этом убеждения в благоприятном исходе расцениваются как цели, которые человек поставил перед собой и стремится достичь. Самооценку иначе можно раскрыть как адекватное оценивание себя, своей возможности справиться со стрессовой ситуацией, а также чувство собственного достоинства. Согласно авторской модели, калифорнийские ученые определили источники копинг-ресурсов: генетика и социальное окружение, в котором проходила социализация человека [12].

Таким образом, под копинг-ресурсами следует понимать индивидуальные и средовые (то есть находящиеся в окружающей человека среде) средства, условия, возможности, которые имеются в наличии в потенциальном состоянии и которые человек может актуализировать, использовать при необходимости в целях совладания с трудной жизненной ситуацией. В качестве копинг-ресурсов можно выделить следующие: тип темперамента, локус-контроль, мотивация достижения, Я-концепция, ответственность, эмпатия, открытость к общению, открытость опыту, саморегуляция, оптимизм [3]. Данный подход обосновывает взаимосвязь темперамента (как совокупности степени нейротизма и направленности личности, согласно модели Г. Айзенка) и копинг-стратегий, выбираемых человеком при стрессе. В то же время, затрагивая проблему достаточности копинг-ресурсов, в отношении типа темперамента целесообразнее говорить о качестве составляющих данного ресурса - нейротизме и направленности личности. Так как все копинг-ресурсы в процессе противостояния воздействию стрессора истощаются, для их восполнения требуется наступление благополучного периода в жизни человека. Если восполнение ресурсов не происходит, а воздействие стресс-фактора не превращается, то создается ситуация дефицита копинг-ресурсов с формированием хронического стресса [1], приводящая к деформации направленности личности (уход в себя, не желание взаимодействовать с окружающими), а также повышению уровня эмоциональной неуравновешенности [4]. На основании изученных публикаций, можно выделить взаимосвязь типа темперамента с применяемыми копинг-стратегиями. Личность с высокой степенью экстраверсии и низкой степенью нейротизма легко переносит стресс, прибегая при этом к социальной поддержке - либо в качестве сотрудничества, объединяя людей для решения проблемы, либо передавая решение проблемы другому человеку [2]. Также прибегает к активному решению проблемы, отвечая при этом за собственные поступки и мысли, а также регулируя их. Проявляя в большей степени положительные эмоции, такие люди позитивно смотрят на стрессовую ситуацию, принимая ее как жизненный урок [6]. Стратегию избегания применят, скорее всего, в тех случаях, когда проблема, вызывающая стресс, кажется им незначительной, и они предпочитают ее решению приятное времяпрепровождение в компании близких и друзей.

Личность с низкой степенью экстраверсии и низкой степенью нейротизма также является устойчивой к стрессу. Ее тяжело вывести из равновесия, спровоцировав на проявление агрессии. Воздействие стрессора не подрывает ее мотивацию и работоспособность - она упорно продолжит решать вызывающую стресс проблему [6]. Однако, переживая сильный стресс в одиночку, и не прибегая к социальной поддержке, флегматик может «заедать стресс» и «копить все в себе». Это приводит к лишнему весу, а также проблемам функционирования щитовидной железы. Как правило, флегматики стараются избегать стресса.

Личность с высокой степенью экстраверсии и высокой степенью нейротизма хоть и будет применять активные действия при преодолении стресса, но будет воспринимать действие стресс-фактора (и 
проблему) как вызов себе. В решении проблемы пойдет до конца. В случае неудачи, выплеснет отрицательные эмоции (гнев и злость) на окружающих людей, которых она привлекли для решения проблемы - либо из-за их действий, которые могут показаться холерикам неправильными, либо же просто «вымещает на окружающих негатив» [2]. Стресс может увеличиваться из-за нежелания показывать свои слабости и адекватно оценить свои силы.

Личность с низкой степенью экстраверсии и высокой степенью нейротизма является самым неустойчивым к стрессу типом темперамента. Находясь в состоянии стресса, она может легко растерять контроль над своими эмоциями, мыслями, а также мотивацию к действию и решению проблемы. Будучи интровертом, меланхолик будет прибегает к помощи и поддержке лишь тех людей, которым очень доверяет и внимания которых не стесняется. Вместе с этим меланхолик будет пытаться действовать для решения проблемы [2]. В случае, если он решится на это в одиночку, то будет испытывать сильное эмоциональное напряжение, выражающееся в агрессии, панике, а также повышенной плаксивости. Однако не стоит воспринимать меланхоликов как совершенно беспомощных и слабохарактерных людей. Усилием воли они могут побороть эмоциональность, приложив все старания для достижения цели и не зависимо от внешнего влияния самостоятельно разрешить проблему, полностью осознавая свои действия.

Таким образом, применяемые человеком стратегии борьбы со стрессом и его преодоления являются актуальной проблемой для зарубежных и российских ученых. В аспекте данного вопроса ведутся активные изучения и исследования видов стратегий, особенностей выбора личностью тех или иных стратегий, а также большое внимание уделяется копинг-ресурсам, непосредственно влияющим на формирование и выбор, среди которых можно выделить темперамент, как совокупность степени направленности и степени нейротизма.

\section{Список литературы.}

1. Дорьева Е.А. Проблема достаточности ресурсов совладающего поведения // Вестник КГУ им. Н.А. Некрасова. - 2013. - №5. - С. 191-194.

2. Кленова М.А., Лаврентьева М.Ю. Влияние типа темперамента на выбор личностью стратегии преодоления // Альманах современной науки и образования. - 2015. - №8. - С. 63- 65.

3. Корзун С.А. Локус-контроль как копинг-ресурс совладающего поведения студентов педагогического вуза // Репозиторий БГПУ. - Режим доступа: https://core.ac.uk/download/pdf/743355641.pdf (дата обращения: 02.07.19).

4. Красильников И.А. Ценностная конфликтность, копинг-статегии и темперамент / И.А. Красильникова // Известие Саратовского государственного университета. Серия Акмеология образования. Психология развития. - 2012. - С. 29- 32.

5. Селье Г. Стресс без дистресса. М.: Прогресс, 2002. - 336 с.

6. Сергеева М.А., Пройдисвет А.П. Взаимосвязь темперамента человека и копинг- стратегий / М.А. Сергеева, А.П. Пройдисвет // Наука и инновации в XXI веке: актуальные вопросы, открытия и достижения. - 2017. - С. $219-222$.

7. Хачатурова М.Р. Совладающий репертуар личности: обзор зарубежных исследований // Психология. Журнал Высшей школы экономики. - 2013. Т. 10, № 3. - С. 160-169.

8. Aldwin C.M., Sutton K.J., Lachman M. The development of coping resources in adulthood // Journal of personality. - 1996. Vol. 64. Issue 4. - P 837-871.

9. Amirkhan J.H. Seeking person-related predictors of coping: Exploratory analyses // European Journal of Personality. - 1999. Vol. 4. - P. 13-30.

10. Folkman S., Lazarus R.S. Coping as a mediator of emotion // Journal of Personal and Social Psychology. 1988. Vol. 54. - P. 466-475.

11. Folkman S. Stress, positive emotion, and coping / S. Folkman, J. T. Moskowitz // Current Directions in Psychological Science. - 2000. Vol. 9. Issue 4. - P. 115-118.

12. Taylor S.E., Stanton A.L. Coping Resources, Coping Processes, and Mental Health // Annual Review of Clinical Psychology. - 2007. Vol . 3. - P. 377-401. 


\section{СОЦИОЛОГИЧЕСКИЕ НАУКИ}

\section{СОЦИАЛЬНО-ДЕМАГРАФИЧЕСКАЯ СТРУКТУРА В ТАДЖИКСКОЙ РЕСПУБЛИКЕ}

Аннотация: После получения независимости в таджикистане произошли некоторые изменения в структуре демографического общества, неравномерно распределённое население таджикистана, главным образом в быстро развивающемся среднем западе, в то время как в горно-бадахшан на востоке наблюдается самая низкая плотность населения и медленное социальное развитие.Доля населения города таджикистана составляет около $30 \%$, и существует тенденция к обратной урбанизации.Таджикистан является молодой страной с относительно большим населением молодежи и активными ресурсами рабочей силы.Но ситуация с трудовым обеспечением в таджикистане неблагоприятна, поскольку доля безработных составляет почти $50 \%$, и выбор большого числа рабочих мест в такие страны, как Россия, в качестве рабочих мест оказывает определенное влияние на долгосрочное развитие страны и региональную безопасность.

Ключевые слова: Таджикистан; Население; Социальная структура

Население является одним из элементов, составляющих государство и самым важным активом страны.Исследование демографических проблем является одной из самых важных и важнейших областей в исследовании социальных проблем страны, а также одним из важнейших аспектов изучения политических, социальных и экономических проблем страны.Таджикистан находится в центре азиатско-европейского континента, вдали от океанов, климат характеризуется сильной континентальной сушей и засухой, климатические условия на востоке и западе отличаются друг от друга, таким образом, распределение населения также зависит от климатических условий.Горные и горные плато в пределах территории тауэрского государства составляют $90 \%$ от общей площади и около половины от общей высоты более 3000 метров над уровнем моря, что является непригодным для обитания человека.Естественное распределение населения тесно связано с такими факторами, как естественная среда, климатические условия региона, а также с такими факторами, как питание и питание для населения.Основными демографическими и экономическими видами деятельности в тауэрском государстве являются горы, расположенные между бассейнами и долинами, а низкими горами и низкими горами в северных, центральных и юго-западных районах являются наиболее интенсивные места распределения населения страны.После распада советского союза население таджикистана стало «стабильным и стабильным», с каждым годом число рождений стабильно росло, число смертей в основном было равным или слегка возросло, а природосберегающее прирост растет год за годом. Таджикистан, Один из стран центральной азии, тесно связан с нашей страной в плане истории и этнических групп, и исследование вопроса о народе таджикистана, кажется особенно важным для нашей страны.В этой статье в первую очередь изучается социальная структура населения таджикистана в таких областях, как региональное распределение населения, структура города и деревни, структура возраста, а также уровень образования населения таджикистана, а также влияние на его социальное развитие, региональную безопасность и т.д.

I Социально-демографическая структура Таджикистана

\section{1. Географическая структура населения}

В настоящее время в Таджикистане действуют два области, автономная область, город центрального подчинения, и территория республики непосредственно под центральным правительством. И в таблице 1 приведены изменения в численности населения во всем таджикистане. Судя по объективным условиям этих пяти административных единиц объективные условия природной среды и климатических условий ГорноБадахшанской автономной области и пригодность населенных пунктов являются наихудшими. Пострадавшие от эт х условий, эта автономная область имеет наименьшее население и самый медленный темп роста.Из-за этих условий в этом районе наименьшее население и самый медленный рост. Статистика показывает, что в 2000 году население Горно-Бадахшанской автономной области составляло 206 000 . Через 10 лет население всего штата по-прежнему составляет 206000 человек к 2010 году, а доля населения в стране поддерживается примерно на 3 процента. Основной причиной низкой численности населения и медленного роста государства является влияние природной среды и климатических условий, то есть на нее влияет географическая среда жителей. 
ТАБЛИЦА 1

ИЗМЕНЕНИЯ В НАСЕЛЕНИИ РАЗНЫХ РЕГИОНОВ ТАДЖИКИСТАНА С 2000 ПО 2010 ГОД (ТЫС. ЧЕЛ.)

\begin{tabular}{|c|c|c|c|c|c|c|}
\hline \multirow[b]{2}{*}{ Район } & \multicolumn{2}{|c|}{$\begin{array}{c}\text { Численность } \\
\text { населения } \\
\end{array}$} & \multirow{2}{*}{$\begin{array}{c}\text { Соотношение } \\
\text { между } 2010 \text { и } \\
2000 \text { годами（ } \\
\%)\end{array}$} & \multicolumn{3}{|c|}{$\begin{array}{c}\text { Увеличение населения с } 2000 \text { по } 2010 \\
\text { год }\end{array}$} \\
\hline & 2000 & 2010 & & Всего & $\begin{array}{l}\text { Естественный } \\
\text { рост }\end{array}$ & Миграция \\
\hline Таджикстан & 6127 & 7565 & 123 & 1438 & 1563 & -125 \\
\hline $\begin{array}{c}\text { Горно-Бадахшанская } \\
\text { автономная область }\end{array}$ & 206 & 206 & 99.93 & 0 & 12 & -12 \\
\hline Согдийская область & 1872 & 2237 & 119 & 365 & 412 & -47 \\
\hline Хатлонская область & 2150 & 2676 & 124 & 526 & 591 & -65 \\
\hline Душанбе & 562 & 724 & 129 & 162 & 148 & 14 \\
\hline $\begin{array}{c}\text { Районы } \\
\text { республиканского } \\
\text { подчинения }\end{array}$ & 1337 & 1722 & 129 & 385 & 400 & -15 \\
\hline
\end{tabular}

(Источник: СМ.艾莱提·托洪巴依主编. 中亚五国人口研究[M]. 北京: 科学出版社, 2014.)

Как видно из таблицы 1, за исключением Горно-Бадахшанской автономной области, население Таджикистана и Согдийской области, Хатлонской области, районы республиканского подчинения и города Душанбе увеличилось с 2000 по 2010 год. : Таджикистан увеличился на 1,438 млн., т.е. на 23,5\%, Согдт увеличился на 365000 , т.е. на 19,5\%, а Хатлон увеличился на 526 000, т.е. на 24,5\%,районы республиканского подчинения увеличились на 385000 человек, т.е. на 28,8\%, город Душанбе, увеличился на 162000 человек, т.е. на 28,8\%.Видно, что регионы с быстрым ростом населения расположены в центральных и западных районах страны, перед низкими горами или по обе стороны реки. Столица Душанбе находится в бассейне Гиссара на высоте 750-930 метров. Аналогичная ситуация наблюдается и в других городах центрального правительства.

Географическая структура населения в основном является результатом социально-экономического развития, однако нынешняя ситуация с географической структурой населения в свою очередь оказывает значительное влияние на развитие социальной экономики. Например, распределение и перераспределение населения в разных регионах оказывает очень непосредственное влияние на корректировку компоновки производительных сил, а также на развитие и использование природных ресурсов. Население постепенно распространилось с наиболее подходящей природной среды на периферию. В то же время первоначальная бесплодная земля была разработана и даже сформирована в новом экономическом центре. В центральных и западных районах страны, перед низкими горами или по обе стороны реки Таджикстана именно климат здесь мягкие, не только подходят для населенных пунктов, но также способствуют развитию сельского хозяйства и животноводства, промышленного производства и транспортировки, чтобы обеспечить потребности людей. Поэтому уровень жизни этих городов намного выше, чем на Востоке. Оригинальные жители готовы продолжать сохранять, но также могут привлекать иностранных жителей (например, восточных жителей) для работы и проживания здесь. Таким образом, население в центральных и западных регионах и городах увеличилось, а темпы роста в восточном регионе и сельском населении были медленными.

\section{2.Городская и сельская структура населения}

Если в советский период в стране росло и городское, и сельское население, то за последние 11 лет городское население уменьшилось (это не в последнюю очередь связано с выездом русскоязычного населения) на 45,8 тысячи человек (на 2,7\%), а сельское выросло на 1063,7 тысячи человек (на 30,9\%). При этом доля городского населения упала с 33\% в 1989 до 26\% в 2000 году. 
ТАБЛИЦА 2

ГОРОДСКОЕ И СЕЛЬСКОЕ НАСЕЛЕНИЕ ТАДЖИКИСТАНА (ТЫСЯЧ ЧЕЛОВЕК)

\begin{tabular}{|c|c|c|c|c|}
\hline Год переписи & Все население & Городское & Сельское & $\begin{array}{c}\text { Доля городского } \\
\text { населения (\%) }\end{array}$ \\
\hline 1979 & 3801 & 1325 & 2476 & 34.9 \\
\hline 1989 & 5109 & 1668 & 3441 & 32.6 \\
\hline 2000 & 6127 & 1623 & 4504 & 26.5 \\
\hline 2005 & 6550 & 1729 & 4821 & 26.5 \\
\hline
\end{tabular}

(Источник: СМ. 艾莱提·托洪巴依主编. 中亚五国人口研究[M]. 北京: 科学出版社, 2014.)

Из таблицы 2 видно, что с 1979 по 2010 год городское население Таджикистана увеличилось с 1,325 млн. До 1,874 млн. Очевидно, что прирост населения очень мал. По сравнению с городским населением численность сельского населения составляет от в 1979 году число 2,467 миллиона человек увеличилось до 5,188 миллионов в 2010 году, а население увеличилось на 2,712 миллиона, что является большим увеличением. Из доли городского населения в общей численности населения он снизился с 34,9\% в 1979 году до $26,5 \%$ в 2010 году, что на $8,4 \%$ меньше.

Это также отражает процесс борьбы с деурбанизацией в Таджикистане. Дезурбанизация в Таджикистане в постсоветский период является следствием гражданской войны и социальноэкономического кризиса, которые сопровождались массовыми перемещениями населения как внутри страны, так и за ее пределы. В частности, период 1991-2001 годов характеризуется двумя волнами миграции из Таджикистана русскоязычного населения, основная часть которого проживала в городах. Первая волна миграции имела место в 1990-1991 годах, сразу после распада СССР. Поводом для второй волны в 19921995 годах стала гражданская война в Таджикистане. При этом вторая волна была гораздо мощнее, чем первая - около 100 тыс. семей, опасаясь трагических последствий войны,были вынуждены окончательно покинуть Таджикистан и переселиться в РФ, Украину, Белоруссию, Германию, Израиль, Казахстан и Узбекистан. Мотивы переезда сельских жителей в города за последние 20 лет серьезно изменились. Если в 1991-2001 гг. сельское население перебиралось в города в поисках безопасности, то в 2001-2010 гг. основными мотивами стали социально-экономические факторы. Однако такой прирост городского населения нестабилен, поскольку невозможность найти работу и рост цен на продовольствие зачастую вынуждают мигрантов возвращаться обратно в село.

Распад СССР и получение независимости страной сопровождались в Таджикистане гражданской войной (1992-1997г.г), что привело к массовому оттоку городских жителей, большинство которых составляло русскоязычное население. Например, отток русских, украинцев и белорусов оказал определенное влияние на увеличение городского населения Таджикистана, потому что в советский период россияне были политическими, экономическими, технологическими и в Таджикистане из высокого уровня образования. Многие из различных отделов образования занимают важные позиции и играют важную роль в социальной жизни Таджикистана, в основном это городское население, поэтому потеря этих не предметных национальностей привела к потере большого количества высококвалифицированных рабочих сил и социально-экономического развития Таджикистана. Это тяжелый удар.

\section{3. Возрастная структура}

Социальное воздействие возрастной структуры населения впервые показано как влияние на рождаемость, смертность и уровень воспроизводства населения. Возрастная структура населения обычно относится к трем различным типам: молодым, взрослым и пожилым людям. Если возрастная структура молода, это означает, что число людей, вступающих в брак и детородный возраст, возрастет, а рождаемость возрастет. Напротив, если возрастная структура стареет, это снизит рождаемость, уменьшит рождаемость и даже может привести к атрофии общего населения. Возрастная структура населения также оказывает незаменимое влияние на структуру образования, структуру потребления, политику социального обеспечения, трудовые ресурсы и проблемы занятости. Многие социально-экономические политики должны основываться на возрастной структуре населения. В то же время возрастная структура населения является важной основой для изучения и анализа молодежи и старения населения, а также разработки национальной политики в области народонаселения и планов развития населения. (Таблица 2.5) 


\section{ВОЗРАСТНАЯ ГРУППА ПОСТОЯННЫХ ЖИТЕЛЕЙ ТАДЖИКИСТАНА}

ТАБЛИЦА 3 (1 ЯНВАРЯ 2010 Г.)(ТЫС. ЧЕЛ.)

\begin{tabular}{|c|c|c|c|}
\hline \multirow{2}{*}{ Возрастной диапазон } & \multicolumn{3}{|c|}{ Общая численность населения } \\
\cline { 2 - 4 } & общий & мужчина & Женщина \\
\hline $0 \sim 4$ & 941.0 & 481.9 & 459.1 \\
\hline $5 \sim 9$ & 828.0 & 424.6 & 403.4 \\
\hline $10 \sim 14$ & 866.1 & 440.0 & 426.1 \\
\hline $15 \sim 19$ & 869.0 & 441.0 & 413.3 \\
\hline $20 \sim 24$ & 833.1 & 419.8 & 321.6 \\
\hline $25 \sim 29$ & 645.9 & 324.3 & 256.0 \\
\hline $30 \sim 34$ & 506.5 & 250.5 & 226.0 \\
\hline $35 \sim 39$ & 443.4 & 217.4 & 201.3 \\
\hline $40 \sim 44$ & 393.7 & 192.4 & 186.6 \\
\hline $45 \sim 49$ & 366.3 & 179.7 & 91.5 \\
\hline $50 \sim 54$ & 270.3 & 133.0 & 50.8 \\
\hline $55 \sim 59$ & 179.4 & 87.9 & 34.6 \\
\hline $60 \sim 64$ & 100.3 & 49.5 & 42.9 \\
\hline $65 \sim 69$ & 72.7 & 38.1 & 34.1 \\
\hline $70 \sim 74$ & 82.6 & 39.7 & 30.3 \\
\hline $75 \sim 80$ & 62.5 & 28.4 & 3752.9 \\
\hline Более 80 & 68.4 & 28.1 & 3776.3 \\
\hline Всего & 7529.2 & \multicolumn{3}{|c|}{. } & & \\
\hline
\end{tabular}

(Источник: СМ. 艾莱提·托洪巴依主编. 中亚五国人口研究[M]. 北京: 科学出版社, 2014.)

Судя по статистике, опубликованной в Таблице 3 , Таджикистан является молодой страной. Всего в возрасте 60 лет насчитывается только 386500 пожилых людей, что составляет 5,13\% от общей численности населения страны. Население от 0 до 39 лет имеет 59,3300 млн. Человек, что составляет 78,8\% от общей численности населения, а население в возрасте 40-59 лет составляет лишь 1,2097 млн. Человек, что составляет всего $16,1 \%$ населения. При постоянном росте и темпах естественного роста население страны, вероятно, будет еще моложе.

В международном сообществе от 15 до 64 лет, как правило, перечисляются как население трудоспособного возраста. Из данных в таблице 2.2 видно, что население населения Таджикистана в возрасте 15-64 лет составляет 4607900 человек, то есть рабочая сила, на долю которой приходится $61 \%$ общей численности населения. Население людей в возрасте до 15 лет и старше 64 составляет 2921300 человек, то есть не рабочая сила, на которую приходится $39 \%$ от общей численности населения.

Поскольку население трудоспособного возраста в возрасте от 15 до 64 лет создает общественное благосостояние, помимо собственного потребления также необходимо поддерживать иждивенцев в возрастных группах от 0 до 14 и 65 лет и старше. Из этого можно сделать вывод, что население трудоспособного возраста в Таджикистане доля населения, на долю которого приходится более половины населения, может повысить уровень жизни людей, факторы социальной стабильности и уменьшить возникновение ряда социальных проблем, что оказывает положительное влияние на формирование структур образования, структур потребления, политики социального обеспечения и социально-экономической политики. Хорошая основа была обеспечена долговременной стабильностью и устойчивым развитием.

II Ситуация образования и занятости населения Таджикистана

3.1 Ситуация образования

В советский период государство придавало большое значение образованию. После обретения независимости Таджикистан унаследовал прекрасную традицию Советского Союза по приданию важности образованию, последовал за системой образования Советского Союза и продолжил практику светского образования, но отменил предоставление бесплатного образования. Государство поощряет частные школы, и ситуация с государственными школами и негосударственными школами сосуществует. В этой ситуации не все дети и люди, которым нужно учиться, могут позволить себе начать учебу. Это неизбежно скажется на качестве граждан и уровне образования. В частности, гражданская война оказывает наибольшее влияние на образование. По неполным статистическим данным, во время Гражданской войны 17 школ были полностью разрушены, 79 школ были частично разрушены, а 45 профессионально-технических училищ были частично или полностью уничтожены. Отсутствует национальное финансирование образования, и отсутствуют учебники, учебные материалы и оборудование. Заработная плата учителей слишком низкая, что приводит к большому оттоку учителей. После появления частных школ число школ увеличилось, но 
число учеников не увеличилось, особенно число учащихся средних специальных школ. Вышеизложенная ситуация имеет большое влияние на образование страны, и она также имеет далеко идущие последствияЭто не только повлияет на настоящее, но также может повлиять на будущее.

В 1990-е гг. в Таджикистане обозначилась тревожная тенденция к все большему сокращению времени пребывания детей в школе и снижению качества получаемого ими образования, причем данное явление заявляло о себе не только в сельской местности, но и в крупных городах - так, в период с 1999 по 2003 гг. произошло значительное снижение посещаемости детьми начальной школы (Таджикистан в цифрах 2010). Несмотря на некоторое увеличение финансирования образовательной системы страны из государственного бюджета, большинство школ испытывают недостаток материально-технического оснащения и обновленных учебных программ.

В сфере школьного образования Таджикистана существует целый ряд проблем, которые руководству страны не удавалось решить на протяжении многих лет. К таковым относится хроническая недостаточность финансирования, сокращение числа дошкольных и общеобразовательных учреждений, а также несоответствие качества обучения государственным стандартам образования. Ситуация осложняется нехваткой учителей, а также затрудненностью посещения школ детьми в труднодоступных районах страны.

Что касается высшего образования, то, очевидно, слабая школьная подготовка абитуриентов снижает уровень поступающих в высшие учебные заведения. Кроме того, вузам Таджикистана был нанесен существенный урон в ходе гражданской войны, когда происходил массовый отток русскоязычных специалистов, в том числе преподавателей, из страны; престиж высших учебных заведений стал падать (Шарипов 2000). Отсутствие квалифицированных преподавателей и по сей день сказывается на качестве подготовки студентов, а также на состоянии научно-исследовательской базы университетов.

В настоящее время, степень образования для граждан Таджикистана, мы можем привести два набора цифр для анализа. Одна группа - это количество студентов университетов на 10000 жителей. В 2010 году количество студентов университетов в Таджикистане составляло в среднем 20000 учащихся на 10000 жителей. В год независимости (1991 год) этот показатель составлял 124 человека. Напротив, наблюдался больший рост. Другая группа в среднем состоит из 50 учащихся на 10000 жителей в средних профессиональных учебных заведениях. В год независимости (1991 год) этот показатель составлял 73 года. Напротив, население значительно сократилось. В целом, растет или уменьшается население, оно попрежнему остается низким для абсолютных чисел.

Образование, особенно высшее, имеет огромное значение для развития НИР и определяет способности овладевать инновациями и адаптироваться к ним. Страны, опережающие другие по темпам развития НИР, приобретают долгосрочные преимущества над конкурентами. Укрепление образования поможет улучшить научную культуру населения, идеологическое и нравственное качество, тем самым способствуя устойчивому развитию общества, регулируя социальные конфликты и способствуя гармоничному и здоровому социальному развитию. Для того, чтобы Таджикистан развивался всесторонне, необходимо уделять первоочередное внимание развитию образования. Ключом к развитию образования является создание современной концепции образования, а не только для исключения абсолютной изоляции иностранной культуры, но и для предотвращения развития этнического образования исключительно в доминирующей культурной модели. Лидеры должны постепенно формировать современную образовательную осведомленность, менять обратную сторону, заставлять людей осознавать актуальность принятия современного образования и приобретения производственных и жизненных навыков, активно развивать современное этническое образование и вносить должный вклад в модернизацию этнического общества, экономики и населения.

3.2 Ситуация занятости населения

Занятость является одной из сфер, где три компонента политики, направленной на человека, человеческое развитие,человеческая безопасность и человеческие права - сводятся в одну точку. В Республике Таджикистан уделяется большое внимание совершенствованию политики занятости как неотъемлемой части социальной политики государства и методам ее реализации.

Исходя из норм, определенных законодательством Республики Таджикистан, число официально зарегистрированных безработных в службах занятости населения на конец мая 2008 г. в Таджикистане составило 50,9 тыс. человек. Из них женщины составили 26,6 тыс.

Среднемесячная номинальная заработная плата в январе - мае 2008 г. по сравнению с соответствующим периодом 2007 г. выросла в 1,4 раза и составила 210,56 сомони. Реальная заработная плата, рассчитанная с учетом индекса цен на потребительские товары, за этот же период по сравнению с прошлогодним показателем выросла на 14,4\%.

Вместе с тем исследования показывают, что в службу занятости населения обращаются не все безработные. Данные проведенных обследований показали, что уровень общей безработицы с учетом определений и методологии Международной организации труда значительно выше, чем уровень регистрируемой.

В 2007 г. средний уровень заработной платы в Таджикистане вырос на 41,1\% и составил 156,74 сомони (1 долл. - 3,49 сомони). Но рост инфляции, который в прошлом году составил 19,7\%, фактически поглотил это достижение. Например, мука - один из основных продуктов питания в Таджикистане, за год подорожала 
на 70\%, а нефтепродукты более чем на 50\%, что в итоге стало причиной скачка цен на все виды продукции и услуг. Стоимость потребительской корзины для трудоспособного населения за прошлый год составила 203,57 сомони, для пенсионеров - 154,1 сомони, для детей - 185,47 сомони и согласно реальному потреблению составляет 161,36 сомони. За 2007 г. наибольшая средняя заработная плата была отмечена в связи - 409,35 сомони, строительстве - 429,11 сомони, транспорте - 394,39 сомони и промышленности 297,39 сомони, а самый низкий уровень наблюдался в области сельского - 47,99 и лесного - 51,85 сомони хозяйств.

Во время переходного периода рынок труда Таджикистана претерпел значительные трудности,связанные с массовым увольнением из государственных предприятий, неспособностью формально частного сектора поглотить увеличившееся количество населения в трудоспособном возрасте,эмиграцией квалифицированных работников, а так же массовой сезонной эмиграцией, особенно в Россию и Казахстан. Одновременно развивался неформальный сектор, обычно в форме сельских хозяйств и торговли. Таким образом, с 1991 г. характер трудоустройства изменился. Государство больше не является основным работодателем, его заменил частный сектор. Большие государственные предприятия в промышленности и сельском хозяйстве, которые в прошлом предоставляли рабочие места подавляющей части рабочей силы в Таджикистане, перестали существовать. Многие предприятия были либо разрушены или перестали функционировать во время и после гражданской войны. Несмотря на приватизацию некоторых промышленных объектов и услуг, а так же осуществление земельной реформы, разрешающей образовывать мелкие земельные хозяйства,частный сектор развивается медленно, и никоим образом не может возместить потерю, государственных рабочих мест. Крупные промышленные и сельскохозяйственные комплексы остаются в собственности государства, но они настолько обременены задолженностями и нуждаются в модернизации, что их приватизация трудно исполнима. Таким образом, значимость различных секторов тоже изменилась. Наибольшая потеря рабочих мест произошла в строительстве и производящей промышленности. Сельское хозяйство, однако, остается доминирующим сектором по трудоустройству. Еще одна черта изменившейся системы трудоустройства связана с тем, что оно создано в небольших и маленьких компаниях и посредством патентной деятельности. Бывшие крупные государственные предприятия, которые требовали определенных навыков, открыли дорогу частному предпринимательству в маленьких и средних компаниях, особенно в неформальном секторе.В результате требуемые типы знаний, навыков и ориентации значительно изменились. Эти изменения вылились в высокий уровень безработицы, широко распространенную бедность, увеличение неформальной экономики, основанной на основных нуждах, и высокий уровень внутренней и внешней миграции.

Высокий уровень рождаемости в последние десятилетия увеличил количество населения в трудоспособном возрасте. Эта часть населения возросла с 2,5 миллионов в 1991 г. до 3,9 миллионов в 2006 г. (общее население: 7,1 миллионов в апреле 2007 г. с городским населением в 2 миллиона).

Таджикский рынок труда испытывает недостаток квалифицированных работников практически во всех областях промышленности (медицина, строительство и т.д.), он недостаточно структуризирован и на 70\% является сельскохозяйственным. Главными его характеристиками является безработица и низкая заработная плата. Позиция женщин на формальном рынке труда очень слаба. Женщины обычно трудоустраиваются на низкооплачиваемую работу, особенно в сфере образования, здравоохранения и сельского хозяйства, где процентное отношение женщин намного выше, но профессиональный уровень очень низок.

Во время первого квартала 2009 г. 119 ярмарок труда было организовано, во время которых 3058 человек были трудоустроены и еще 1827 человек были направлены на повышение квалификации.

Однако, согласно сообщениям трудовых мигрантов, предприятия, участвовавшие в ярмарках труда, предлагали низкую заработную плату, которая не соответствовала даже минимальному уровню,утвержденному правительством.

Экономический рост является результатом трудовой деятельности человека и сам создает основы для расширения возможностей занятости либо в виде дополнительных рабочих мест, либо в виде принципиально новых видов работ. Таким образом, экономический рост и занятость выступают одновременно как источник и результат друг друга.

\section{Заключение}

Социальная структура населения является важной частью демографических проблем Таджикистана, мы лучше поняли демографические проблемы Таджикистана и помогли нам понимать в политике, обществе и экономике Таджикистана.

За время гражданской войны экономика Таджикистана была подорвана. Таджикистан стал одной из беднейших стран мира. Огромное количество беженцев покинуло страну. Многие таджики эмигрировали в Афганистан. Кроме того, многие русские, немцы, украинцы, евреи и представители других некоренных народов вынуждены были искать убежища в России и других странах. Это влияло на социальнодемографическую структуру Таджикстана.

Интенсивный рост населения Таджикистану уже давно вызывает озабоченность правительства. Еще в 2002 году президент страны Эмомали Рахмон провел совещание, посвященное демографическим проблемам, планированию семьи и устойчивому развитию. Президент заявил, что вопросы регулирования рождаемости в Таджикистане не являются частным, семейным делом граждан, а входят в круг 
государственных проблем. По предложению главы страны были разработаны и утверждены «Концепция государственной демографической политики» и «Программа реализации Концепции государственной демографической политики на 2003-2015 гг.», целью которой являлось создание условий для становления рационального типа демографического развития и повышения качества жизни населения. Правительство Таджикистана прилагает усилия для принятия соответствующих мер по повышению уровня образования людей и качества населения, а также для усиления макроконтроля над перемещениями населения. Цель состоит в том, чтобы производство населения не только соответствовало собственным законам населения, но и делало это развитие экономики будет скоординировано для адаптации надстройки к экономической основе.

\section{Список литературы}

[1] Бададжнова Р. М. Человеческое развитие[М]. Душанбе, 2014.

[2] Баходур Эшонов и его группа.Урбанизация в Центральной Азии:вызовы, проблемы и перспективы[М]. Ташкент, 2013.

[3] Петрушков М.Г. Анализ демографической картины Республики Таджикистан[М]. Екатеринбург, 2007.

\section{Электронные ресурсы:}

[1] Михаил Петрушков, Демографическая политика в Республике Таджикистан. -Режим доступа: http://cabar.asia/ru/mihail-petrushkov-demograficheskaya-politika-v-respublike-tadzhikistan/.2016

[2] Демографические аномалии Таджикистана | Общество | Диалог: Таджикистан и мир -Режим доступа : http://www.dialog.tj/news/demograficheskie-anomalii-tadzhikistana.2016. 


\title{
ТЕХНИЧЕСКИЕ НАУКИ \\ УДК 519.24 \\ АЛГОРИТМ ПОДГОТОВКИ ТАБЛИЦЫ МНОГОМЕРНЫХ ПАССИВНЫХ ЭКСПЕРИМЕНТАЛЬНЫХ ДАННЫХ ДЛЯ ПОЛУЧЕНИЯ АДЕКВАТНЫХ МАТЕМАТИЧЕСКИХ МОДЕЛЕЙ
}

\author{
Долгов Юрий Александрович
} академик РАЕН,

доктор технических наук, профессор Приднестровского государственного университета им. Т.Г. Шевченко,

2. Тирасполь

Балашова Юлия Владимировна

стариий преподаватель кафедры интегрированных компьютерных технологий и систем Приднестровского государственного университета им. Т.Г. Шевченко,

2. Тирасполь

Терещенко Елена Владимировна старший преподаватель кафедры программного обеспечения вычислительной техники и автоматизированных систем Приднестровского государственного университета им. Т.Г. Шевченко,

2. Тирасполь

Аннотация. Рассматривается алгоритм сокращения размерности факторного пространства экспериментальных данных без существенной потери полезной информации с целью получения адекватной многомерной математической модели и определения её информационной ёмкости.

Abstract. It is shown the algorithm of factor space dimension reducing of experimental data without any information loss to generation of adequate multivariate mathematical model and its information capacity.

Ключевые слова: размерность факторного пространства, адекватная математическая модель, информационная ёмкость.

Key words: factor space dimension, adequate mathematical model, information capacity.

Пассивный эксперимент представляет собой наблюдение и фиксацию числовых значений, параметров (факторов) и целевых функций объекта исследования при его естественном ходе без искусственного вмешательства экспериментатора [3]. Результатом является таблица, $N$ строк представляет собой конкретные числовые значения целевой функции при конкретном наборе факторов, а $M$ столбцов числовые (бальные, дихотомические) значения каждого фактора в отдельности, то есть $M$ выборок объёмом $N$ каждая. Из этой таблицы предстоит извлечь скрытую информацию в виде многомерной регрессионной модели, что представляет достаточно сложную задачу.

Во-первых, вопреки классической теории планирования эксперимента [1], никакого искусственного изменения (управления) факторов нет, а имеет место беспорядочное, иногда довольно маленькое, варьирование, и чтобы отличить воздействие конкретного фактора на целевую функцию от шума эксперимента требуется достаточно длинная таблица.

Во-вторых, в первоначальном списке могут быть сильно коррелированные факторы, что, как известно $[3,1]$, не способствует нахождению математической модели объекта исследования. Необходимо из каждой пары (или группы) сильно коррелированных факторов выбрать для дальнейших вычислений только один, что существенно сокращает размерность факторного пространства, а это, в свою очередь, существенно сокращает трудоёмкость нахождения модели. Наиболее простым способом осуществить эту операцию является метод корреляционных плеяд [4].

В-третьих, в первоначальном списке также могут оказаться факторы, не влияющие на целевую функцию, но, к сожалению, это можно выяснить либо непосредственно в ходе моделирования, либо дополнительными экспертными исследованиями.

Таким образом, алгоритм подготовки исходных пассивных экспериментальных данных к адекватному моделированию может быть представлен в виде нижеприведённого рисунка. 


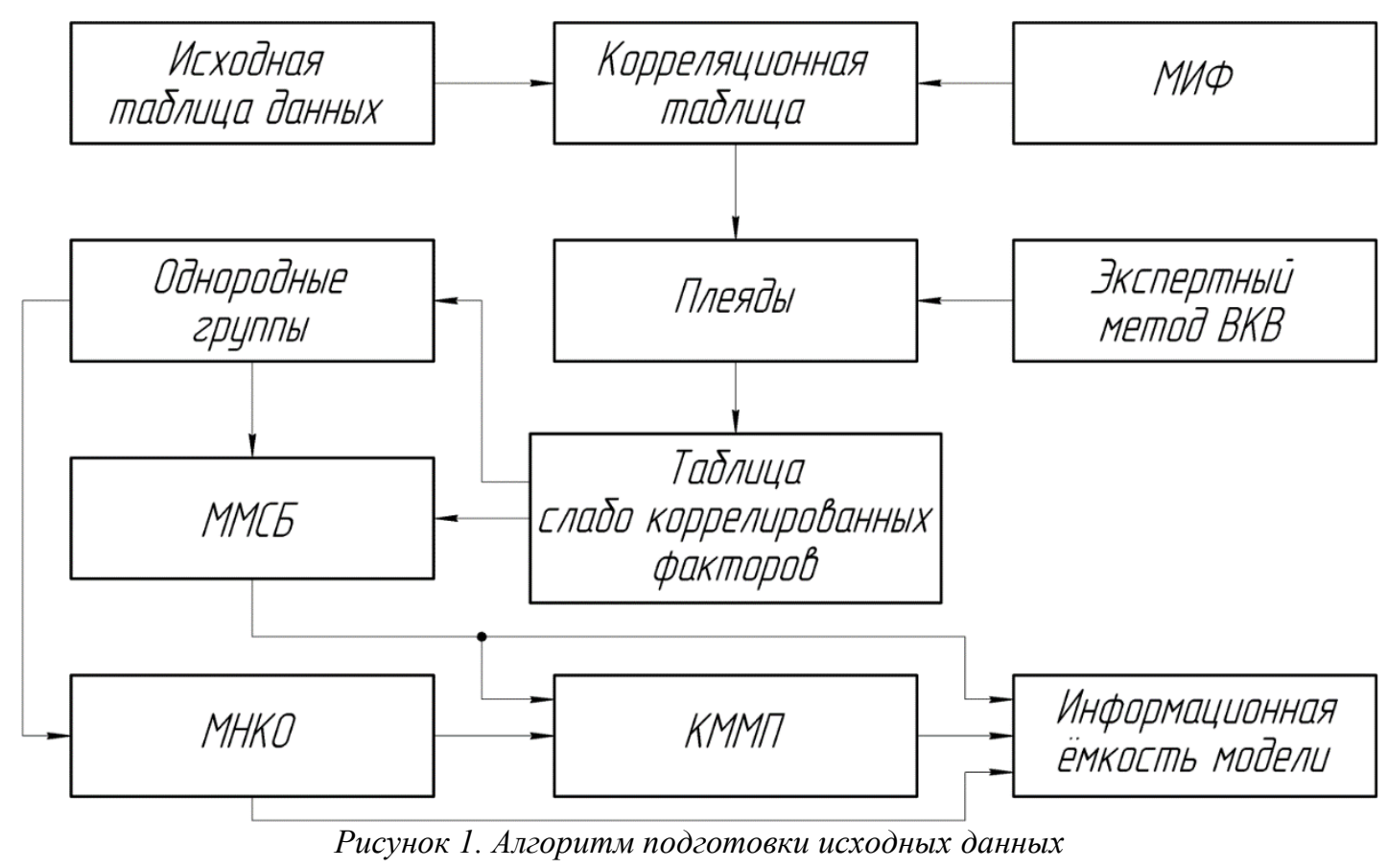

Из опыта нашей работы ясно, что корреляционную таблицу лучше всего вычислять не с помощью коэффициента линейной корреляции, пригодных только при числовых представлениях данных, а с помощью модифицированного индекса Фехнера (МИФ) [3,2], который практически совпадает по величине с коэффициентом корреляции в диапазоне значений $|0,2-1,0|$ но в отличии от него носит универсальных характер, то есть, пригоден для использования не только числовых данных, но и балльных, и дихотомических, чего коэффициент корреляции не может. Кроме того, МИФ нечувствителен к наличию в таблице данных грубых промахов как линейного, так и парного характера до 6-7\% от объёма выборки, тем самым отпадает трудоёмкая процедура их поиска и замены.

Выделение из каждой плеяды главного фактора можно производить любым экспертным методом, однако, на наш взгляд, наиболее удобным для этого является метод весовых коэффициентов важности (ВКВ) [3], который не только вдвое точнее любого другого экспертного метода, но и обладает рядом только ему присущих преимуществ: удобство работы эксперта, определение коэффициента компетентности (непротиворечивости ответов) эксперта и, следовательно, возможности отсева заведомо ложных экспертиз, а также выявление отдельных факторов, по которым мнения экспертов разошлись, и доказательство непротиворечивости конечной ранжировки законам природы.

Что касается непосредственно адекватного моделирования, то укажем на три авторских метода: модифицированный метод случайного баланса (ММСБ) [3]; метод наименьших квадратов с предварительной ортогонализацией факторов (МНКО) [3]; комбинированный метод моделирования по пассивным данным (КММП) [3]. Кроме того, все эти три метода могут быть дополнительно оценены по качеству с помощью коэффициента информационной ёмкости [3], то есть, по количеству информации, которую модели выбрали из таблицы данных.

ММСБ - самый скоростной метод, менее трудоёмок, его коэффициенты одновременно являются весами факторов, однако он требует длинной таблицы данных, не даёт квадратичных членов, факторы представлены в относительном виде, что затрудняет использование модели, а информационная ёмкость составляет $15-30 \%$.

МНКО - обладает повышенной трудоёмкостью, которая удваивается с каждым новым фактором; может использоваться при малом числе строк таблицы данных $(N \geq \mathrm{s})$ при условии, что число столбцов хотя бы на единицу меньше; может работать при повышенной корреляции между факторами; может давать квадратичные, кубичные и т.д. члены; модель представлена в естественных единицах измерения факторов; информационная емкость модели составляет 30-65\%.

КММП является комбинацией ММСБ и МНКО; информационная емкость модели составляет 50-85\%.

\section{Выводы}

Использование предложенного алгоритма гарантирует получения высококачественный математической модели, пригодной как для управления, например, технологическим процессом; так и для совершенствования объекта исследования.

\section{Список литературы}

1. Адлер Ю.П., Маркова Е.В., Грановский Ю.В. Планирование эксперимента при поиске оптимальных условий. -2-е изд., перераб., и доп.- М.: Наука, 1976 - 279 с. 
2. Долгов Ю.А., Долгов А.Ю., Терещенко Е.В. Модифицированный индекс Фехнера как мера тесноты линейной связи (Вестник Приднестр. Ун-а. - 2015 - N3 - С. 92 - 98).

3. Долгов Ю.А. Статистическое моделирование: Учебник для вузов.-2 изд. доп.-Тирасполь: Полиграфист , 2011-352c.

4. Дружинин Г.В. Методы оценки и прогнозирования качества - М.: Радио и связь 1982-160с.

\section{РАЗРАБОТКА МОДЕЛИ УПРАВЛЕНИЯ ПРОИЗВОДСТВЕННОЙ СИСТЕМОЙ НА БАЗЕ КЛАССИЧЕСКОЙ ТЕОРИИ АВТОМАТИЧЕСКОГО УПРАВЛЕНИЯ}

Сергеев Антон Владимирович

Кандидат технических наук,

ФГБОУ ВПО «Самарский государственный технический университет»,

Настоящая работа является продолжением исследований автора и его коллег вопроса о возможности применения математического аппарата и методов классической теории автоматического управления (ТАУ) для анализа и синтеза систем управления производственными и бизнес-процессами предприятий. Конечную цель предпринятого исследования автор видит в разработке единой методологической платформы, как для построения отдельных функциональных блоков систем, так и автоматизированных систем управления предприятиями ERP-класса в целом, в том числе реализующих и оптимальные алгоритмы управления [2].

В работе [3] была предложена математическая модель автоматизированной системы управления складом в форме дискретной передаточной функции (рис. 1).

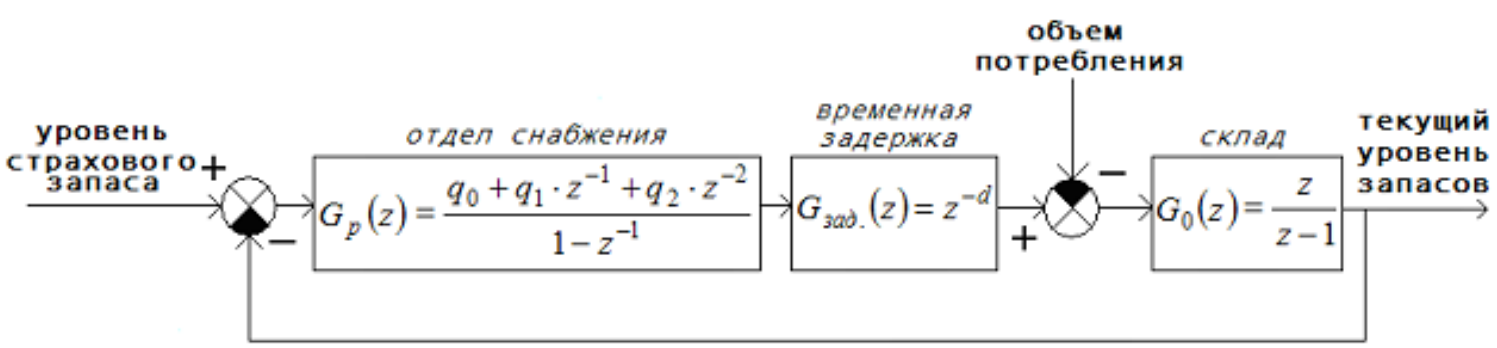

Рисунок 1. Структурно-функииональное представление модели управления запасами

В приведенной модели входным сигналом является заданный уровень так называемого «страхового запаса». Объектом управления является склад, который представлен в модели интегрирующим звеном. На входе объекта управления действует возмущающее воздействие - потребление сырья и материалов со склада. Органом управления является структурное подразделение предприятия (например, отдел снабжения), отвечающее за обеспечение производственного процесса необходимыми материалами, или в более узком смысле - поддерживающее необходимый уровень запасов на складах. Его передаточная функция определяется применяемым в подразделении алгоритмом расчета необходимого объема заказа на основании информации о разнице между текущим и заданным уровнем запасов (т. е. принятым алгоритмом регулирования уровня запасов). Исходя из практики построения систем автоматического управления наиболее широко используемым алгоритмом регулирования является ПИД-алгоритм, который и предлагается применять здесь в указанных целях. В связи с наличием временных задержек по поставкам в модель управления включено звено запаздывания. Процесс учета товарно-материальных ценностей на складе представляет собой обратную связь в системе управления запасами

Попробуем распространить подход к моделированию производственных объектов, предложенный в [3], на обобщённое представление производственной системы, включающей в себя три объекта, связанных между собой материальными потоками: склад сырья и материалов, производственную площадку (цех) и склад готовой продукции. Определим, что главной и непосредственной целью управления такой системой будет являться обеспечение бесперебойного производства требуемого объёма конечной продукции, который в свою очередь будет определяться спросом на неё со стороны её покупателей. При известном графике реализации готовой продукции могут быть без принципиальных трудностей однозначно определены все остальные составляющие производственного процесса. Применительно к рассматриваемой здесь производственной системе это - график производства продукции и графики поставки сырья и материалов на предприятие и выдачи их в производство. При этом ключевым условием, соблюдение которого необходимо при определении графиков движения материальных потоков в производственной системе, исходя из указанной выше цели управления, является их согласованность между собой в смысле равенства суммарных приходов и расходов материалов. В противном случае, несогласованность графиков поставки и производства, рано или поздно, может привести к сбоям в работе предприятия или к срыву поставок готовой продукции по одной из следующих причин: возникновение дефицита тех или иных материалов, или готовых изделий; затоваривание одного из участков производственной системы. 
В реальных условиях добиться абсолютной сбалансированности производственной системы в указанном выше смысле не представляется возможным в силу наличия случайных факторов, вызывающих отклонения от плановых графиков движения материальных потоков. И самым существенным из таких факторов, определяющим интенсивность движения всех материальных потоков в системе, является спрос на продукцию предприятия, в силу случайного характера которого график её реализации будет представлять собой случайный процесс. В этом случае принципиально невозможно заранее, для каждого момента времени, определить такой объём производства, который бы строго соответствовал спросу на производимую продукцию. Как известно, широко распространённым решением, позволяющим снизить риск остановки производства и неудовлетворения спроса, является создание запасов исходного сырья и материалов и готовой продукции. В упомянутой выше работе [3] показано, что в системе управления материальными потоками, математическая модель склада, как объекта управления, основной функцией которого является накопление и хранение запасов, в теории автоматического управления может быть представлена типовым интегрирующим звеном. Контролируемым параметром склада в этом случае является уровень запасов, текущее значение которого равно разности между суммарным приходом материалов на склад и суммарным расходом материалов со склада за период с начального до текущего момента времени, с учётом имевшихся на начальный момент времени на складе остатков запасов:

$$
L(k)=\sum_{n=1}^{k} P(n)-\sum_{n=1}^{k} R(n)+L_{0}
$$

где $L$ - уровень запасов на складе; $P$ - приход материалов на склад; $R$ - расход материалов со склад; $L_{0}$ - уровень запасов на начальный момент времени. Отметим, что рассматриваемые здесь и далее производственные процессы, включая и движение материалов на складе, можно считать дискретными, поскольку в дальнейшем нас будут интересовать их значения только в определённые моменты времени, когда, в соответствии с установленным графиком работы, лицо ответственное за материально-техническое снабжение производства, производит контроль состояния материальных запасов. Безусловно, движение материалов происходит и между этими моментами времени, однако соответствующие промежуточные состояния игнорируются системой управления, то есть другими словами можно сказать, что они для неё не существуют.

Преобразуем уравнение (1) следующим образом:

$$
L(k)=L_{0}+\left(\sum_{n=1}^{k-1} P(n)-\sum_{n=1}^{k-1} R(n)\right)+(P(k)-R(k)),
$$

то есть выделим из суммы всех поступлений на склад значение прихода в текущий момент времени $k$ и из суммы всех убытий со склада - значение расхода, также соответствующее текущему моменту времени (вторая скобка в уравнении (2)). Оставшиеся слагаемые - $L_{0}+\left(\sum_{n=1}^{k-1} P(n)-\sum_{n=1}^{k-1} R(n)\right)-$ определяют уровень запасов на момент времени $k$-1. Таким образом, из уравнения (2) следует, что уровень запасов в текущий момент времени $k$ равен сумме его значения в предыдущий момент времени $k-1$ и разности между текущим приходом и расходом (3):

$$
L(k)=L(k-1)+(P(k)-R(k)) .
$$

Переходя к операторной форме записи разностного уравнения, построим дискретную передаточную функцию склада как объекта управления входным сигналом которого является разность между приходом и расходом материалов, а выходным - контролируемый параметр - уровень запасов (4) - (7).

$$
\begin{gathered}
L(z)=L(z) \cdot z^{-1}+(P(z)-R(z)), \\
L(z)-L(z) \cdot z^{-1}=(P(z)-R(z)), \\
L(z)\left(1-z^{-1}\right)=(P(z)-R(z)), \\
\frac{L(z)}{(P(z)-R(z))}=\frac{1}{1-z^{-1}}
\end{gathered}
$$

Выражение в правой части последнего уравнения, как известно, представляет собой дискретную передаточную функцию типового интегрирующего звена.

С целью обеспечения непрерывности производственного процесса, запасы создаются не только на складах предприятия, но и на производственных площадках, которые в контексте задачи управления материальными потоками, аналогично складам, могут быть представлены интегрирующими звеньями. Таким образом математическая модель всей производственной системы в целом, в рамках аппарата ТАУ, может быть представлена совокупностью интегрирующих звеньев, связанных между собой материальными потоками. Для рассматриваемой здесь системы: исходящий поток со склада сырья и материалов является входящим потоком для производственной площадки, а исходящий поток с производственной площадки является входящим потоком для склада готовой продукции. В математической модели системы в форме передаточных функций данная ситуация будет отображаться путём заведения одного и того же сигнала, моделирующего материальный поток, на вход связанных этим потоком объектов, но с разными знаками: поток со склада сырья и материалов будет действовать в сторону снижения уровня складских запасов и увеличивать уровень запасов на производственной площадке; поток готовой продукции будет уменьшать уровень запасов на производственной площадке и увеличивать, соответственно, уровень запасов готовой продукции на соответствующем складе.

С учётом вышеизложенного передаточная функция производственной системы в целом будет выглядеть следующим образом (см. рис. 2). 


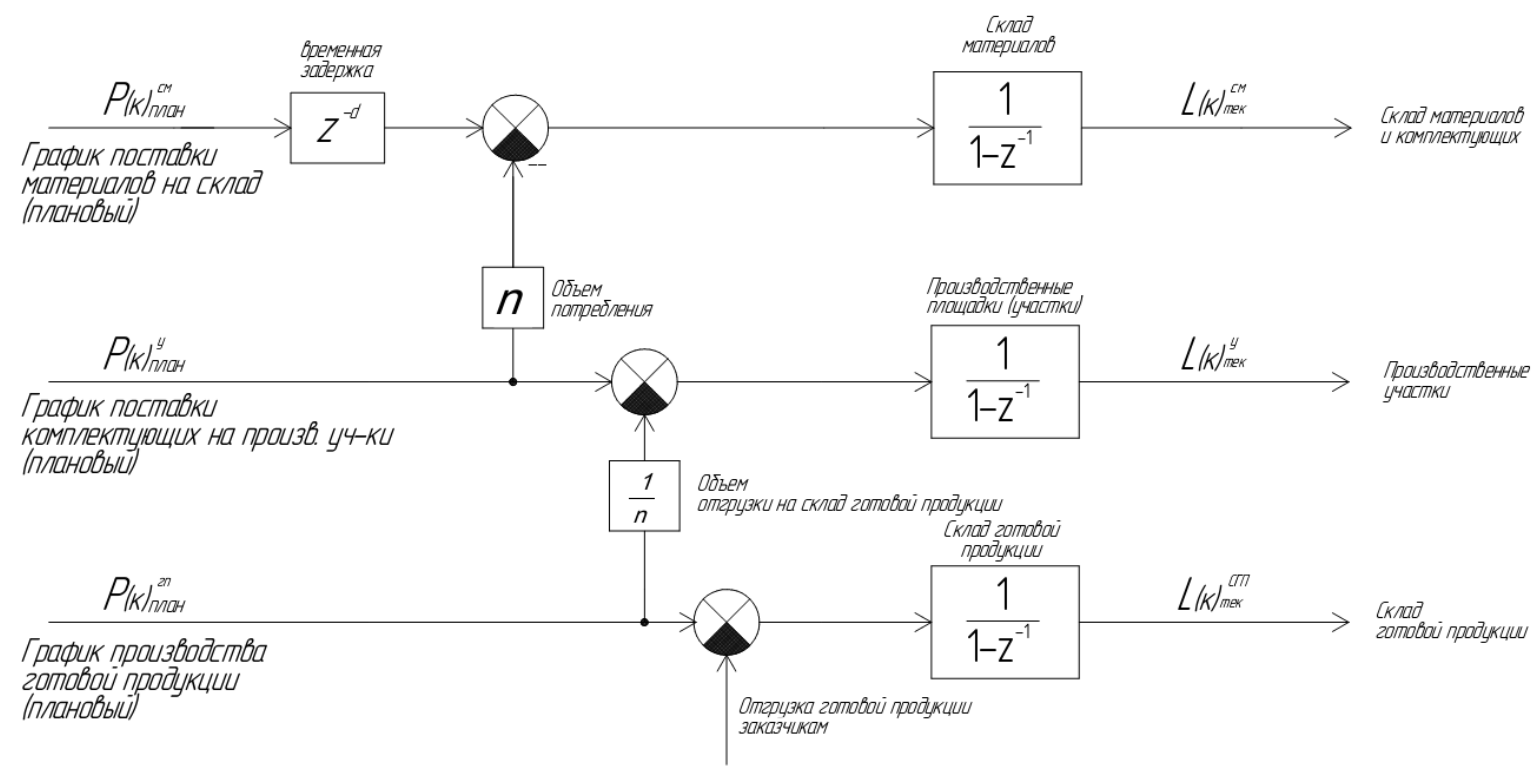

Рисунок 2. Структурно-функциональное представление модели программного управления производственной системой

Здесь пропорциональные звенья с коэффициентами $n$ и $\frac{1}{n}$ между объектами производственной системы предназначены для отображения в модели распространённого подхода к организации производственной площадки, когда в её состав входят $n$ идентичных производственных участков, потребность каждого из которых в материалах удовлетворяется с общего склада материалов, а готовые изделия с них уходят на общий склад готовой продукции. Поскольку мы предполагаем полную идентичность всех $n$ производственных участков, в модели их можно представить одним звеном, отмасштабировав соответствующим образом потоки, связывающие его с остальными звеньями системы (т.е. складами).

На входе системы действуют три управляющих сигнала: графики поставки материалов и комплектующих на склад материалов и на производственные участки и график производства готовой продукции, в совокупности представляющие собой общий план-график производства. Данные графики согласованы между собой и сформированы исходя из предполагаемого спроса на производимую предприятием продукцию, который в рассматриваемой системе, в терминах ТАУ, будет представлять собой возмущающее воздействие, которое системе необходимо отработать. Такой тип управления, когда управляющее воздействие отрабатывает известное возмущение, называется в ТАУ программным управлением [1, с. 71]. Если исключить влияние всех случайных факторов, то при таком подходе, принципиально, можно добиться устойчивого функционирования предприятия при нулевом уровне всех запасов.

Однако, как уже было отмечено выше, в реальных условиях этого достичь невозможно, и минимальный уровень запасов, обеспечивающий стабильную работу предприятия в таких условиях, т.н. «страховой запас», должен быть на каждом из объектов производственной системы. Таким образом, к задаче выполнения заданного графика производства добавляется задача поддержания необходимого уровня страховых запасов. С точки зрения ТАУ здесь идёт речь о классической задаче регулирования, эффективным решением которой является применение отрицательной обратной связи по выходу объекта. Применительно к рассматриваемой здесь системе управление с помощью отрицательной обратной связи будет построено, как показано на следующей функциональной схеме (рис. 3) 


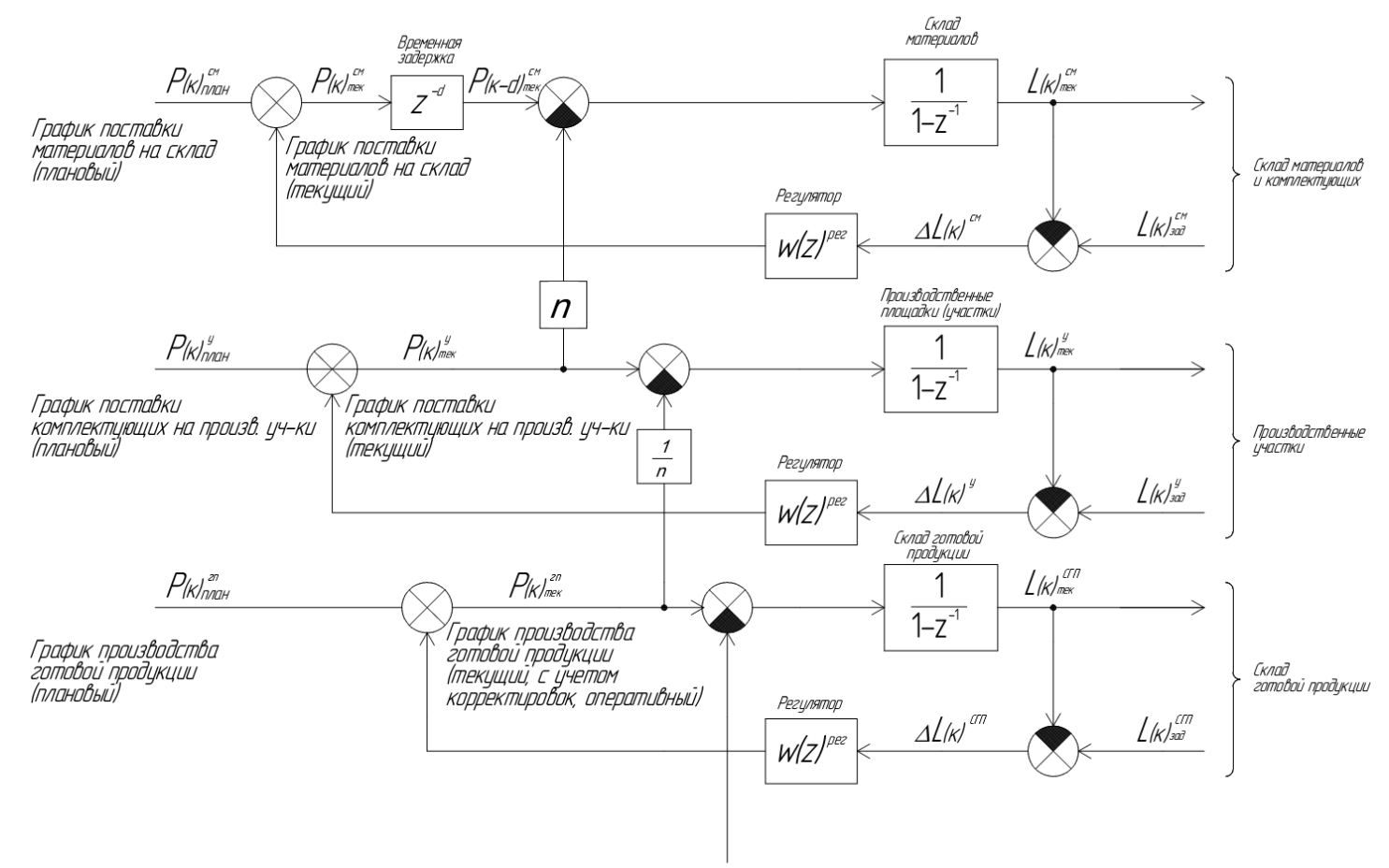

Рисунок 3. Структурно-функциональное представление модели управления производственной системой с обратной связью по ошибке

Здесь выход каждого объекта - текущий уровень запасов - сопоставляется с требуемым уровнем страхового запаса, отклонение от которого поступает на вход регулятора (управляющего устройства). Выход регулятор представляет собой корректировку плановых графиков, обеспечивающую минимизацию выявленных расхождений.

При практической реализации регуляторы будут представлять собой программно-реализованные алгоритмы расчёта корректировок соответствующих плановых графиков производства и поставок, параметры которых будут рассчитаны методами ТАУ, исходя из условия обеспечения требуемых динамических свойств управляемой системы, как минимум - её устойчивости.

Безусловно, практическая реализация предложенного здесь подхода к построению управления производственной системой, в том числе выбор структуры и настройка параметров регуляторов, требуют рассмотрения большого числа деталей, отличающих реально функционирующие предприятия от их модельного представления. Результаты выявления и поиска решения этих проблем автор предполагает представить в своих следующих работах по данной теме.

\section{Список литературы}

1. Первозванский А. А. Курс теории автоматического управления: Учебное пособие. 2-е изд., стер. СПб.: Издательство «Лань», 2010. - 624 с.

2. Сергеев А.В. Предпосылки к применению классического аппарата теории автоматического управления в качестве методологической платформы для разработки ERP-систем. Вестник Самарского государственного технического университета. Серия «Технические науки». Выпуск №2(34): Самара, 2012. С. $39-43$.

3. Сергеев А.В., Новиков А.А. Разработка модели системы управления поставками материалов для промышленных предприятий на базе классической теории автоматического управления // Вестник Самарского государственного технического университета. Сер. Технические науки. - 2013. - № 3(39). C. $41-47$. 


\section{УДК 622.271 .325}

ОСОБЕННОСТИ ПРИМЕНЕНИЯ ТРАНСПОРТНОЙ СИСТЕМЫ RAIL-VEYOR

Труфанова Инна Сергеевна

кандидат технических наук, дочент,

Санкт-Петербургский горный университет,

Попова Юлия Михайловна

студентка,

Санкт-Петербургский горный университет

Аннотация. Статья посвящена рассмотрению задачи, направленной на обоснование применения новой транспортной системы конвейерных поездов, разработанных канадской компанией «Rail-Veyor». B публикации рассматривается конструкция, технические характеристики и особенности применения конвейерных поездов.

Ключевые слова: конвейерный поезд, конвейер, поезд, приводная станция, электродвигатели, тяговое усилие, железнодорожные пути.

Keywords: conveyor train, conveyor, train, drive station, electric motors, traction effort, railway tracks.

Система конвейерных поездов представляет собой отдельные секции грузонесущих тележек, соединенных конвейерной лентой, которые перемещаются по рельсам с помощью внешних промежуточных приводов, установленных стационарно на трассе. Системы конвейерных поездов сочетают преимущества конструкции ленточных конвейеров и железнодорожного транспорта. В отличие от ленточных конвейеров у конвейерных поездов отсутствует перекатывание грузонесущего полотна по роликам, за счёт чего реализуются высокие скорости движения и увеличивается срок службы грузонесущего полотна. В пунктах разгрузки и загрузки поезда движутся с небольшой скоростью. Загрузка горной массы может осуществляться непрерывно. Поэтому устройства для загрузки конвейерных поездов не отличаются от устройств для загрузки конвейеров.

Ещё в 1967 году на одном из меднорудных горных предприятий, расположенных в штате Мичиган, были проведены промышленные испытания конвейерных поездов, разработанных существовавшей в то время компанией «Дашевейер» (рис. 1). Однако конвейерные поезда компании «Дашевейер» так и не получили распространения. В них использовался собственный привод, что усложняло конструкцию поезда, тем самым повышая его стоимость и соответственно затраты на эксплуатационные расходы. $[1,3]$

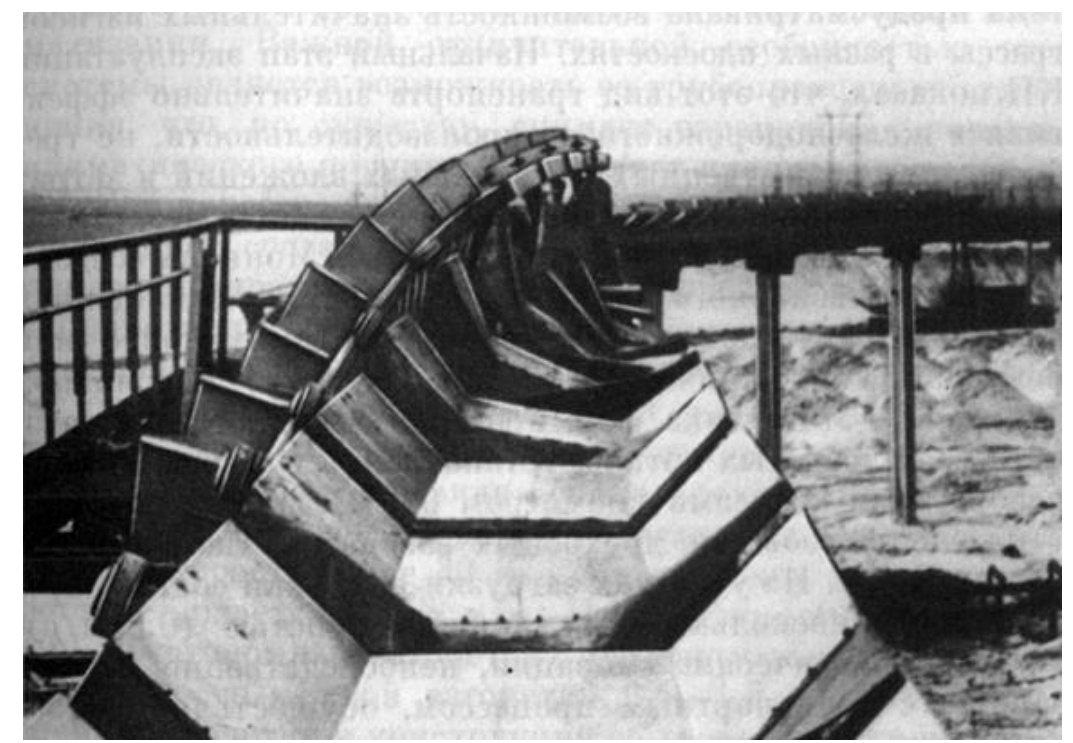

Рис. 1 - Конвейерный поезд, разработанный компанией «Дешевейер» (1967.) [2]

Отличительной чертой новой системы конвейерных поездов, разработанных канадской компанией «RAIL-VEYOR», является использование внешних стационарных промежуточных приводов, расположенных по трассе (рис.2). Передача тягового усилия составу производится за счёт фрикционного воздействия резиновых автомобильных шин на боковые пластины тележек.

Tрасса для системы конвейерных поездов Rail-Veyor может быть изгибающейся и в плане, и в профиле. Угол наклона трассы в вертикальной плоскости составляет 20\%, а радиус закругления составляет минимум 30 метров. Данная система достаточно компактна, что позволяет использовать её в подземных условиях. 


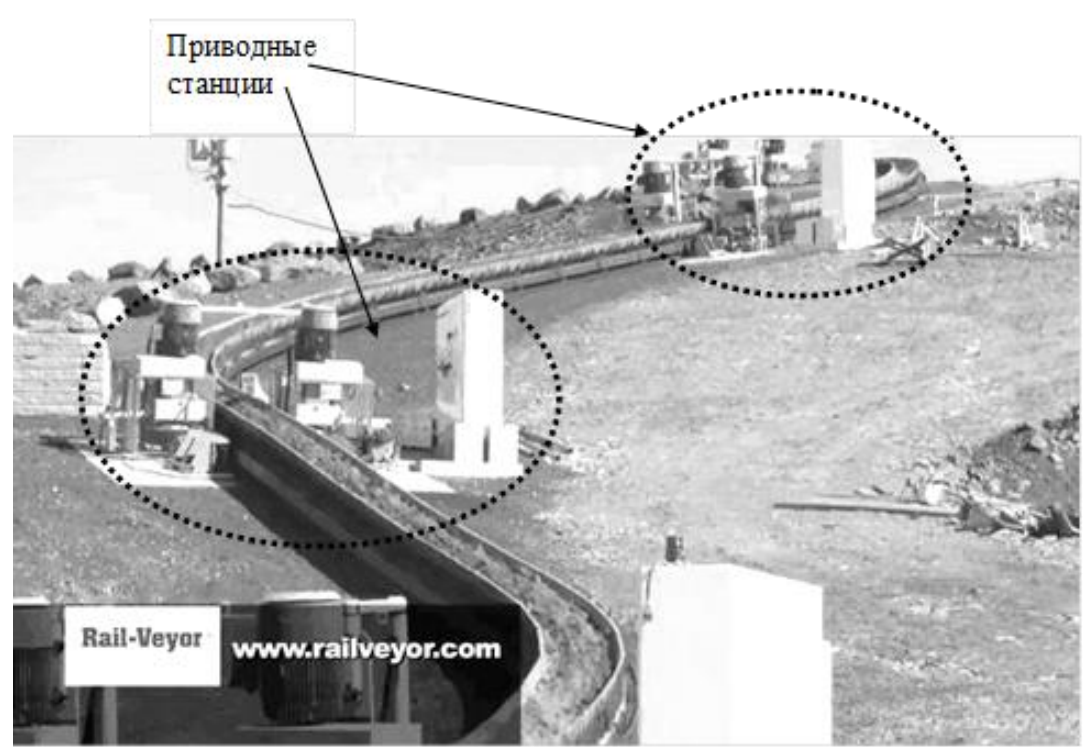

Pис. 2 - Трасса конвейерного поезда Rail-Veyor [4]

Скорость движения конвейерного поезда достигает 36 км/ч $(10$ м/с), каждая секция (движимая на двух колесах) может вмещать до 3 тонн, количество секций в поезде технически не ограничено,

Система приходит в движение за счет фрикционного взаимодействия горизонтально размещенных колес, приводимых в движение электродвигателями, с боковыми пластинами тележек, таким образом происходит перемещение конвейерного поезда (рис.3).

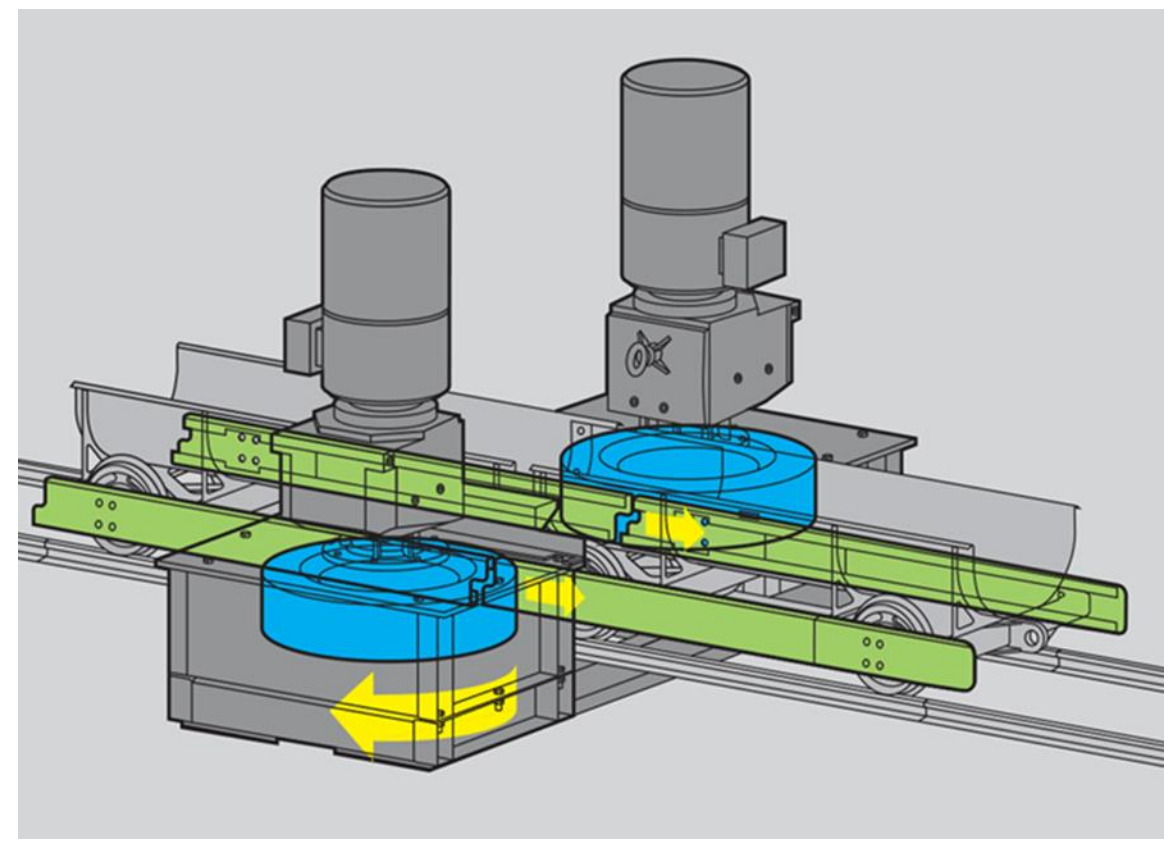

Puс. 3 - Приводная станщия системы Rail-Veyor [5]

Приводная станция данной системы может располагаться как вертикально, так и горизонтально. При подземных горных работах (в условиях ограниченности пространства) целесообразно расположить приводную станцию горизонтально.

Строительство железнодорожных путей для конвейерного поезда фирмы Rail-Veyor занимает относительно немного времени. Это объясняется тем, что в данной системе используются более легкие рельсы (что позволяет уменьшить толщину балластного слоя), а также облегченные стальные шпалы, устанавливаемые просто и быстро, а рельсы соединяются друг с другом с помощью соединительных накладок и болтов. Конструкция быстро-сборочная, что очень удобно при наращивании железнодорожных путей в подземных условиях. Например, бригада из 6 человек может установить 37 метров пути за 1 час. [5] 
Для разгрузки конвейерных поездов необходимо сооружение специальных металлоконструкций Пути конвейерного поезда преобразуются в петлю, а особая конструкция секций конвейерного поезда позволяет горной породе скатываться под тяжестью собственного веса (рис. 4).

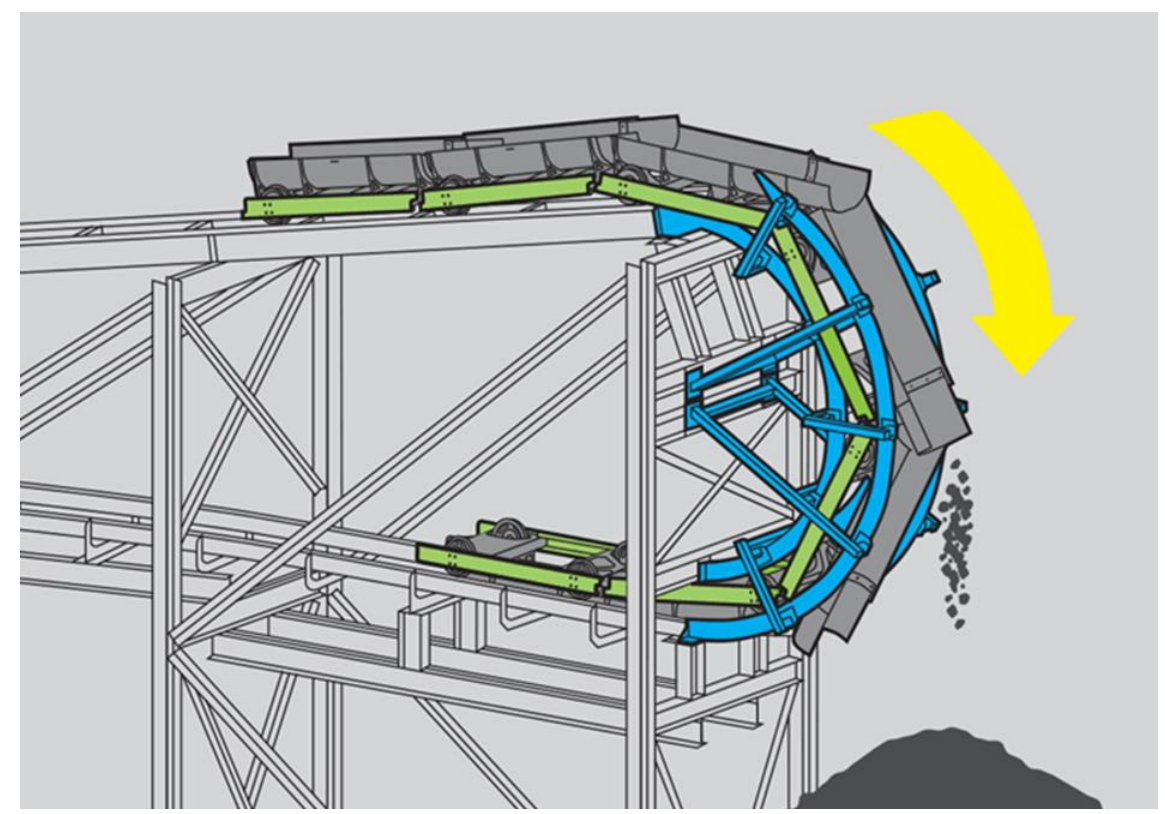

Pис. 4 - Разгрузочная станция конвейерного поезда Rail-Veyor [5]

Главным недостатком этой системы является громоздкость разгрузочной станции.

Разгрузочные станции могут быть сконструированы в виде одной кругообразной петли или двух петель, похожих на знак бесконечности.

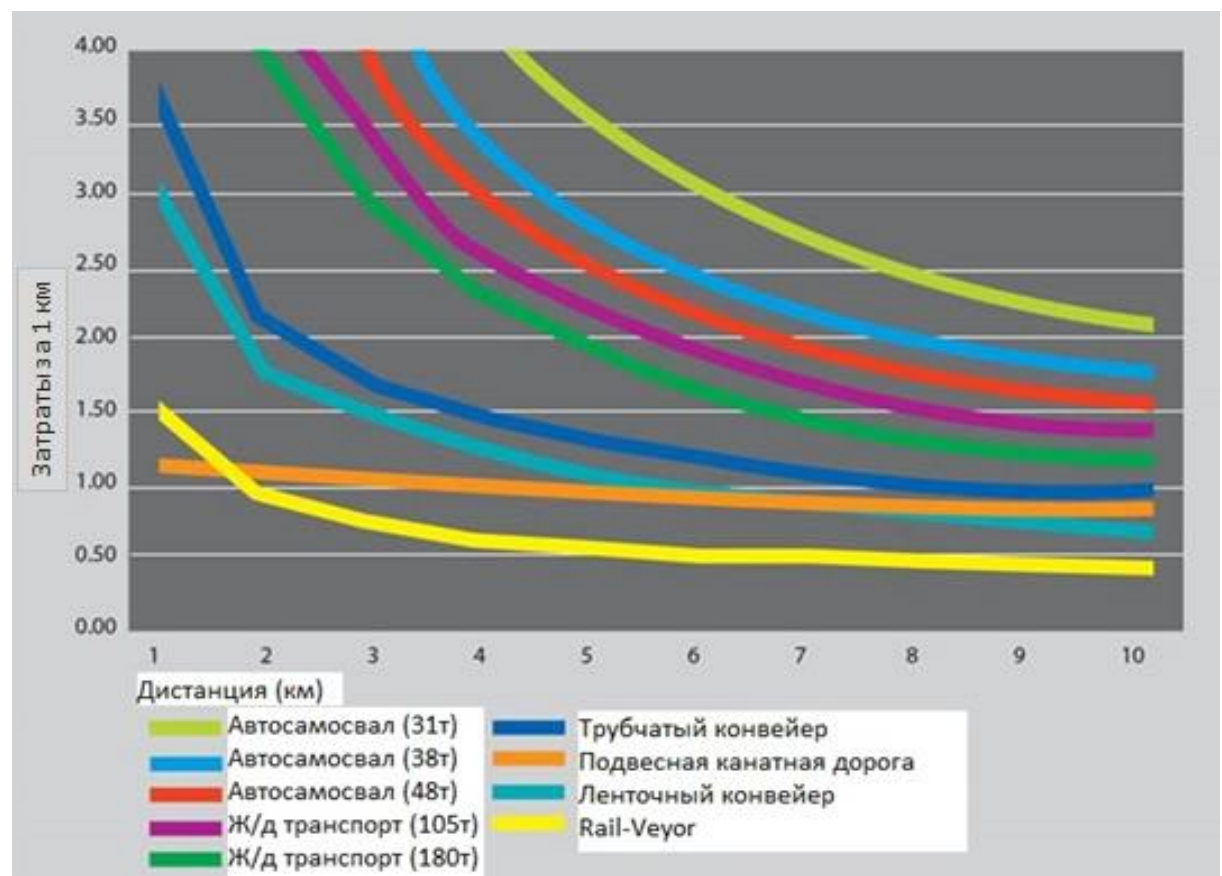

Рис. 5 - График зависимости сравнения затрат транспортной единищы на расстоянии до 10 км [5]

На графике (рис. 5) наглядно можно оценить, как снижаются удельные затраты на каждый километр пути при увеличении пути до 10 км (в данном случае). Зависимость для системы Rail-Veyor представлена ярко-жёлтым цветом (нижняя линия на графике).

Система Rail-Veyor имеет очень низкий коэффициент сопротивления движению, способна перевозить грузы любой абразивности, как сыпучие, так и штучные, и допускает возможность применения разветвленной сети с развилками и пересечениями, что позволяет, например, транспортировать разные фракции горной породы. Также данная система конвейерных поездов не боится снежных северных зим, 
поезд, первая тележка которого оборудована специальным навесным лемехом, сам расчищает перед собой заметенный снегом путь.

\section{Список литературы:}

1. Васильев М.В., Волотковский В.С., Кармаев Г.Д. Конвейеры большой протяженности на открытых горных работах. - М.: Недра, 1977.

2. Горизонты транспортной техники. - М.: Транспорт, 1988. -256 с.

3. Мулухов К.К. Транспортные машины на горных предприятиях США. - М.: Недра, 1981.

4. Труфанова И.С., Лавренко С.А. Горные транспортные машины и оборудование. Применение промежуточных линейных приводов с прижимными элементами для ленточных конвейеров: Учебное пособие. - СПб.: Политехника Сервис, 2019. - 88 с.

5. Транспортная система Rail-Veyor [Электронный ресурс]. - Режим доступа: https://www.railveyor.com/ (Дата обращения 01.07.2019) 


\title{
ФИЛОЛОГИЧЕСКИЕ НАУКИ
}

\section{ИМЯ ДЕЙСТВИЯ/ДЕЯТЕЛЯ В ДРЕВНИХ И НОВЫХ ИНДОЕВРОПЕЙСКИХ И СЕМИТСКИХ ЯЗЫКАХ}

\author{
Балута Анастасия Анатольевна \\ Доцент, доктор филологических наук \\ Московский государственный областной университет, Москва \\ Профессор кафедры романистики и германистики
}

Имя действия и имя деятеля редко выделяется в индоевропейских языках в отдельную категорию и обычно функционирует как отглагольное существительное. Чаще такие формы выделяются в языках арийской (санскрит, хиндустани, панджаби, урду) и иранской ветви (талышский), хотя здесь они могут внешне совпадать с инфинитивом (урду) или восходить к арабским масдарам (талышский).

В санскрите для образования имён существительных, обозначающих действие как процесс, часть тела, выполняющую это действие, а также различные абстрактные понятия, часто употреблялись суффиксы: -ktin, -ghañ, -al (его варианты: -av, -aș) и -anaḍ. Данные существительные являлись довольно древними формами, так как, вступая в соединение со «слабым» глагольным корнем, словообразовательный формант, изменённый по правилам сандхи, практически исчезал. У некоторых существительных, образованных от наиболее древних глагольных основ, в настоящее время суффикс имени действия почти не виден и восстанавливается лишь с помощью этимологического анализа.

1. От глагольных основ с помощью суффикса -ktin (в соединении - ti) образовывались существительные женского рода, склоняющиеся по гласному склонению на $-\check{l}$, типа mati «мнение»: gam «идти» - gati «скорость, цель»; gai «петь» - gīti «песня»; srj «создавать» - sṛșți «создание»; bhaj «воспевать» - bhakti «преданность»; ram «радовать» - rati «любовь, привязанность».

2. От глагольных основ с помощью суффикса - ghañ образовывались существительные мужского рода, склоняющиеся по гласному склонению на - ă, типа nara «человек»: paḍh «читать» - pāḍha «урок»; han «убивать» - ghāta «удар»; kudh «сердиться» - krīdha «гнев»; āh «собирать» - āhāra «еда».

3. От глагольных основ с помощью суффикса -al образовывались существительные мужского рода, склоняющиеся по гласному склонению на - ă, типа nara «человек»: ji «побеждать» - јауа «победа»; vi «собирать» - vaуa «собрание»; nī «нести» - пауа «ноша»; li «таять» - laya «исчезновение»; kṛ «делать» - kara «рука».

4. От глагольных основ с помощью суффикса -anadh (в соединении - an) образовывались существительные среднего рода, склоняющиеся по гласному склонению на - ă, типа phala «фрукт»: śī «спать» - śaya «кровать»; bhram «гулять» - bhramana «прогулка»; pā «пить» - pāna «питьё»; саг «ходить» carana «нога»; loc «смотреть» - locana «глаз» [9, p. 690].

Когда к глагольному слабому корню (обычно с приставкой или в составе сложного слова) добавлялся суффикс -ṇini (в соединении - in), получались существительные мужского или женского рода, обозначающие человека (деятеля), обладающего каким-либо качеством или занимающего какую-либо должность. Склонялись эти имена по согласному склонению, типа guṇin «человек» м. род или nadī «река»ж. род: mantra «советовать» - mantrin «советник, министр»; madyapā «пить вино» - madyapāyin «пьяница»; aparadh «быть виноватым» - aparadhn «грешник, злодей»; grah «хватать, брать» - grahin «получающий качество» [9, р. 691].

В хиндустани имя деятеля (nomen agentis) образуется от основы косвенных форм инфинитива с помощью суффикса -wālā: sunnā «слушать» (инф.)- sunnewālā «слушатель» (имя д.); paṛhnā «читать» (инф.) - parhnewālā «читатель» (имя д.) [1, с. 69].

В панджаби глагольное имя действия с абстрактным значением (обычно женского рода) может выглядеть как чистая глагольная основа, без инфинитивной морфемы -nā/-ṇā: kheḍnā «играть» (инф.) - kheḍ «игра» (имя д.) [8, с. 31]. Имя деятеля образуется от Общекосвенного падежа инфинитива с помощью суффиксов - vāla и -hār. Имя деятеля может иметь как субстантивное, так и адвербиальное значение: vekhaṇvālā «зритель» и «смотрящий»; karanhār «деятель» и «делающий». В то же время имя деятеля в панджаби является аналогом латинского причастия будущего времени и выражает намерение совершить действие: uh āunvvālā hâe «он собирается прийти» или «он вот-вот придет» [8, с. 31].

В языке урду (арийская ветвь) инфинитив одновременно представляет собой имя действия с абстрактным значением: ānā «приходить» и «приход»; jānā «уходить» и «уход»; likhnā «писать» и «писание». В качестве имени действия инфинитив представляет собой форму мужского рода единственного числа и даже различает формы падежей: Прямого и Косвенного. Окончание Прямого падежа инфинитива $-n \bar{a}$ указано в словаре, в Косвенном падеже конечная гласная меняется на $-e$ : ānā - ānē, jānā - jānē. B форме Косвенного падежа инфинитив употребляется со всеми послелогами существительного: рі̄ne kā «питьевой», khāne ko «для еды». В значении имени действия инфинитив употребляется в предложении в тех же функциях, что и существительное: bāhar se naukar ke han̄sne kī āwāz āyī hai «с улицы донесся смех (букв. «звук смеха» слуги»). Форма косвенного падежа инфинитива также может употребляться самостоятельно, без послелога [3, с. 154]. 
В талышском языке (иранская ветвь) значительная часть имен действия (abstracta) образована от арабских имен действия (masdar). Эти глагольные имена склоняются, причем падежное значение у них выражается как с помощью флексий, так и аналитическим путем, посредством предлогов и послелогов. Например, так выглядит флективное выражение Отложительно-направительного падежа с помощью суффикса $-o$ : i gala rǘkü be-šejo «для перехода через речку», «через речку чтобы перейти» (от bе-šе «переходить», «выходить»). Выражение Косвенного падежа с помощью послелога -ro в значении причины и цели: šim ba biǰor bo devan kardé- ro «я пошел на чалтычное поле, чтобы жать» «...для жатвы», «... для делания жатвы». Выражение Местного или Локативного падежа с помощью послелога - ada: išti votéada hozómon «по твоему слову мы готовы» [6, с. 188].

Талышское глагольное имя действия с последлгом - $d a$, присоединив показатели лица, вошло в состав слитно-сложной формы настоящего времени: vaté-da-m «я говорю» и «я в говорении нахожусь». Такая форма похожа на активное причастие в иврите, которое одновременно является формой настоящего времени глагола, но не имеет показателей спряжения. Кроме того, талышское имя действия в Местом падеже с послелогом - ada употребляется для выражения деепричастных значений [6, с. 188].

В языках славянской группы имена действия и деятеля обычно не выделяются в самостоятельную грамматическую категорию, но почти везде существуют отглагольные существительные, которые можно назвать именами действия. Например, в словацком языке такие существительные образуются от глагольных основ с помощью суффиксов -nie, -enie, -tie: čakaf - čakanie «ожидание», praf - pratie «стирка» [7, с. 274]. Аналогичная ситуация существует и в современном русском языке. В болгарском языке глагольное имя действия образуется преимущественно от основ имперфекта с помощью окончания -не и представляет собой форму среднего рода ед. числа: приби́ране реко́лтата «собирание урожая», заси́лване те́мпото «усиление темпа». Это глагольное имя может управлять, как и глагол, прямым дополнением без предлога, в то время как у отглагольных существительных на -ниј, -ениј эта функция отсутствует [5, с. 285]. В этом языке имя действия (почти как в арабском) является эквивалентом выходящего из употребления инфинитива.

В кельтских языках это глагольное имя действия может входить в состав описательного спряжения или употребляться вместо спрягаемой формы глагола. Например, валлийском языке глагольное имя действия с предлогом уn образует в сочетании с глаголом «быть» описательное спряжение: yr wyf yn meddwl «я думаю». Если глагольное имя стоит в начале предложения, то уn может опускаться. В бриттских языках глагольное имя действия часто употребляется в сочетании с глаголом «делать». В валлийском языке это явление наблюдается преимущественно в предложениях с инверсией: a-th gyrchu a wha «и он нападает на тебя» (ср.-вал.); wreugh why tryge «вы не останетесь» (корн.); hoz trugarecat a raf «благодарю вас» (ср.-брет.) $[4$, c. 363]. В валлийском языке имя действия может быть использовано вместо спрягаемой глагольной формы или как infinitivus historicum: a llawen uu y uorwyn wrthaw a chyfarch dwell idaw «и девушки радушно встречали и приветствовали его» (ср.-вал.) [4, с. 363].

В большинстве индоевропейских языков имя действия не выделяется в самостоятельную категорию, но его аналогом можно считать другие глагольные имена субстантивного характера, например, латинский герундий.

В арабском языке имя действия (масдар) может выражать различные значения. 1) Имя действия без дополнительных значений, обозначает глагольное действие: qatl-un «удар», fahm-un «понимание». Это имя изменяется по падежам и является доминантным представителем данной категории. Кроме доминантного имени действия, в арабском языке существует ряд глагольных имен с дополнительными смысловыми оттенками. 2) Имя неоднократности действия: ğalsatun «одно сидение», «заседание». 3) Имя способа действия: mišiatun «манера ходить». 4) Имя места и времени действия: maktabun «место, где пишут», «школа». 5) Имя орудия действия: mibradun «напильник»; 6) Имя сосуда или вместилища: miḥlabun «подойник» [2, с. 386].

В большинстве семитских языков имя действия имя действия так же как и в индоевропейских, в самостоятельную грамматическую категорию практически не выделяется.

\section{Список литературы:}

1. Баранников А.П. Хиндустани (урду и хинди). Учебник. Л., Изд-е Ленинградского Восточного Института, 1934. 518 с.

2. Гранде Б.М. Введение в сравнительное изучение семитских языков. 2-е изд. Монография. М., Издательская фирма «Восточная литература» РАН, 1998. 439 с.

3. Дымшиц 3.М. Грамматика языка урду. Монография. М., Издательская фирма «Восточная литература» PAH, 2001. $596 \mathrm{c}$.

4. Льюис Г., Педерсен Х. Краткая сравнительная грамматика кельтских языков. Пер. с англ. А.А. Смирнова. 2-е изд. испр. Учебное пособие. М., УРСС, 2002. 512 с.

5. Маслов Ю.С. Грамматика болгарского языка. Учебное пособие. М., «Высшая школа», 1981. 407 с.

6. Миллер Б.В. Талышский язык. Учебник. М., Издательство АН СССР, 1953. 267 с.

7. Мистрик Й., Тугушева Р. Учебник словацкого языка: для вузов. М., Высш. школа, 1981. 423 с.

8. Толстая Н.И. Язык панджаби. Учебное пособие. М., Издательство Восточной литературы, 1960. 60 с.

9. Kale M.R. A Higer Sanskrit Grammar. Deli, M/S Gopal Narain \& Co, 1961. 710 p. 


\title{
ГРАММАТИЧЕСКИЕ ТРАНСФОРМАЦИИ ПРИ ПЕРЕВОДЕ ТЕКСТА ЗАКОНА С АНГЛИЙСКОГО ЯЗЫКА НА РУССКИЙ
}

\author{
Краутман Татьяна Евгеньевна \\ кандидат филологических наук, \\ дочент кафедры гуманитарных и сочиильно-экономических дисииплин \\ Крымского филиала Краснодарского университета МВД России, \\ Симферополь
}

В теории перевода принято считать, что типологические признаки юридических текстов характеризуются однородностью, так как их коммуникативная задача состоит в передаче полной и точной информации. Согласно работе И.С. Алексеевой «Профессиональный тренинг переводчика» [1], предписывающий характер текста закона, выражается в ряде лексико-грамматических особенностей, общих для всех юридических текстов. По мнению исследователя, в процессе перевода необходимо обращать внимание на наличие юридических терминов, глаголов в настоящем времени и пассивных конструкций, структур со значением условия и причины, большое количество однородных членов предложения и однородных придаточных, тавтологической когезии.

Следуя за исследованием В.Н. Комисарова «Лингвистика перевода» [3], который выделяет среди характеристик текста как единицы перевода коммуникативную функциональность, ситуативную ориентированность, избирательность способа описания ситуации, И.С. Алексеева обращает внимание, что на процесс перевода юридического текста, в том числе и закона, оказывают влияние стилевые (официальноделовой) характеристики и форма письменной речи, а так же неизбежные отличия в языковых системах.

С.Ю. Соломатина в статье «Грамматические трансформации при переводе текстов с английского языка на русский (на материале английских эссе)» [4] среди причин грамматических расхождений языка оригинала и языка перевода выделяет отсутствие в языке перевода какого-либо элемента, свойственного языку оригинала; наличие в языке перевода элементов формально не соответствующих языку оригинала, но широко применяющихся; наличие в языке перевода грамматических элементов, соответствующих языку оригинала, но выполняющих отличные функции.

Процесс перевода, согласно работе «Язык и перевод» [2] Л.С. Бархударова, должен быть связан с установлением референциальных, прагматических и внутрилингвистических значений знаков, при этом эквивалентность текста оригинала и текста перевода возможно достичь путем сохранения отношений между знаком и предметом, знаком и человеком, знаком и другими знаками. Должен учитывается характер переводимого текста, то есть его жанровая разновидность, которая влияет на преобладание тех или иных значений. Среди способов передачи семантики текста оригинала исследователь выделяет переводческую транслитерацию и транскрипцию, калькирование, описательный перевод, приближенный перевод, трансформационный перевод. Особый интерес представляет последний, который связан с лексикограмматическими трансформациями, подразумевающими необходимость перестройки синтаксической структуры предложения и лексических замен. Сущность перевода Л.С. Бархударов определяет как возможность изменения поверхностной структуры текста при сохранении глубинной структуры. Среди основных поверхностно-синтаксических трансформаций выделяются перестановки, замены, добавления и опущения.

Таким образом, разница в системах языка текста оригинала и текста перевода неизбежно приводит к необходимости в процессе перевода прибегать к лексико-грамматическим трансформациям.

В качестве материала исследования послужила глава «Provisions of the Orders» закона острова Мэн о терроризме и финансировании терроризма («Terrorism and the Financing of Terrorism»), принятый в феврале 2012 года и обновленный 5 февраля 2016 года.

В процессе перевода текста закона с английского языка на русский возможны следующие грамматические трансформации, изменяющие структуру текста:

- перестановка частей сложного предложения, приводящая к замене главных и второстепенных членов предложения:

\begin{tabular}{|l|l|}
\hline \multicolumn{1}{|c|}{ Оригинал } & \multicolumn{1}{|c|}{ Перевод } \\
\hline 16. It is an offence to invite funds, or to receive or & $\begin{array}{l}\text { Привлечение средств или их получение и } \\
\text { обеспечение считается преступлением, если есть }\end{array}$ \\
provide funds if it is known, or there is reasonable cause \\
to suspect, the funds may be used for the purposes of \\
terrorism, or the person or entity appears on a published \\
list.
\end{tabular}


- замена частей речи:

\begin{tabular}{|l|l|}
\hline \multicolumn{1}{|c|}{ Оригинал } & \multicolumn{1}{|c|}{ Перевод } \\
\hline 17. It is an offence to make available any funds or & $\begin{array}{l}\text { Предоставление каких-либо средств, финансовых } \\
\text { financial or related services to, or for the benefit of, } \\
\text { или связанных с ними услуг ради выгоды лиц, } \\
\text { those involved in terrorism, or those controlled by } \\
\text { колерые участвуют в терроризме или тех, кто } \\
\text { находятся под контролем первых или действуют от } \\
\text { их имени, считается преступлением. }\end{array}$ \\
\hline
\end{tabular}

- замена отрицательной формы глагола на положительную:

\begin{tabular}{|c|c|}
\hline Оригинал & Перевод \\
\hline $\begin{array}{l}\text { 18. The Treasury may issue a notice directing that } \\
\text { funds should not be frozen and may not be made } \\
\text { available to any person except under the authority of a } \\
\text { licence issued by the Treasury. }\end{array}$ & $\begin{array}{l}\text { Казначейство может выдать уведомление о том, что } \\
\text { средства не должны замораживаться, но могут } \\
\text { быть предоставлены какому-либо лицу лишь на } \\
\text { основании лицензии, выданной Казначейством. }\end{array}$ \\
\hline
\end{tabular}

- замена местоимения существительным:

\begin{tabular}{|l|l|}
\hline \multicolumn{1}{|c|}{ Оригинал } & \multicolumn{1}{|c|}{ Перевод } \\
\hline $\begin{array}{l}\text { 19. Any person who intentionally engages in activities } \\
\text { designed to enable or facilitate the making available of } \\
\text { funds shall be guilty of an offence. }\end{array}$ & $\begin{array}{l}\text { Виновным в совершении преступления считается } \\
\text { любое лицо, преднамеренно участвующее в } \\
\text { деятельности, направленной на обеспечение или } \\
\text { облегчение предоставления средств. }\end{array}$ \\
\hline
\end{tabular}

- замена глагола существительным и изменение порядка с лов с целью коммуникативного членения предложения:

\begin{tabular}{|c|c|}
\hline Оригинал & Перевод \\
\hline $\begin{array}{l}20 . \quad \text { It is an offence for an institution not to } \\
\text { disclose to the Treasury information relating to those it } \\
\text { had dealings with (since } 10 \text { October 2001), if it knows } \\
\text { or suspects that that person is involved in any way in } \\
\text { terrorism. There is also legal cover for the disclosure } \\
\text { of such information to the Treasury. }\end{array}$ & 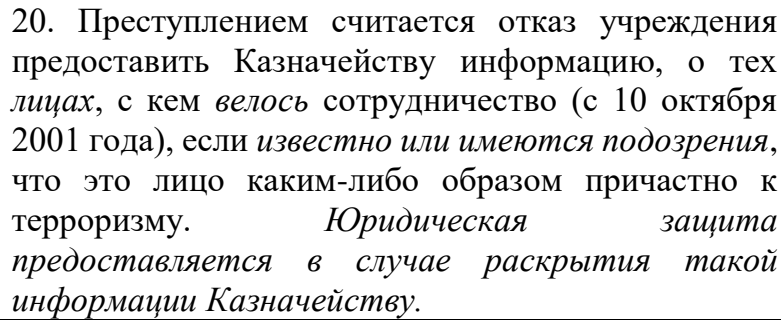 \\
\hline
\end{tabular}

- замена сложного предложения простым:

\begin{tabular}{|l|l|}
\hline \multicolumn{1}{|c|}{ Оригинал } & \multicolumn{1}{|c|}{ Перевод } \\
\hline $\begin{array}{l}\text { 21. The Treasury may issue licences, which must } \\
\text { be in writing, for the release of funds. }\end{array}$ & $\begin{array}{l}\text { 21. Казначейство может выдавать письменные } \\
\text { лищензии для освобождения средств. }\end{array}$ \\
\hline
\end{tabular}

- замена множественного числа местоимения на единственное:

\begin{tabular}{|c|c|}
\hline Оригинал & Перевод \\
\hline $\begin{array}{l}22 . \text { The Treasury can serve a written notice on } \\
\text { anyone to whom the measures apply, requiring them to } \\
\text { furnish the Treasury with any information in their } \\
\text { possession or control, or produce any document in their } \\
\text { possession or control, for the owner of those funds } \\
\text { shall furnish the Treasury with any information in their } \\
\text { possession or control, or produce any document in their } \\
\text { possession or control, for the purpose of allowing the } \\
\text { Treasury to ensure compliance with, or detect evasion } \\
\text { of, the sanctions. Failure to furnish such information } \\
\text { or documents without reasonable excuse is an offence. }\end{array}$ & $\begin{array}{l}\text { 22. Казначейство может направить письменное } \\
\text { уведомление любому лицу, к которому } \\
\text { применяются меры, требуя от него предоставить } \\
\text { любую информацию, находящуюся в его владении } \\
\text { или контроле, или представить любой документ, } \\
\text { находящийся в его распоряжении или контроле, с } \\
\text { целью позволить Казначейству обеспечить } \\
\text { соблюдение санкиий или обнаружить уклонение от } \\
\text { них. Непредоставление такой информации или } \\
\text { документов без уважительных причин является } \\
\text { преступлением. }\end{array}$ \\
\hline
\end{tabular}

Таким образом, примеры перевода текста закона показывают, что

1. Наиболее распространенной грамматической трансформацией является перестановка частей сложного предложения (пп. 16 - 22). Прямой порядок слов утвердительного предложения английского языка заменяется коммуникативным членением предложения [2;118], свойственным русскому языку (пп. $16,17,19,20)$. В данных пунктах тавтологическая когезия в тексте оригинала утрачивает форму и, частично, содержание. При переводе текста закона встречается изменение порядка следования главного предложения 
и придаточного, приводящее к замене синтаксической связи (сложноподчиненное предложение становится сложносочиненным);

2. Текст закона в процессе перевода подвергается таким типам замен, как замена формы слова (множественное число указательного местоимения заменяется на единственное число) (п. 22), замена местоимения существительным (п. 17), замена глагола существительным (п.16, 17, 20, 22).

3. Замена членов предложения, как правило, сопровождается перестроением структуры предложения, что вызвано необходимостью точной передачи коммуникативного членения предложения. Английское подлежащее заменяется при переводе на второстепенный член предложения, а второстепенный член предложения в русском языке становится подлежащим (пп. 16, 17, 20). При замене пассивной конструкции английского языка на активную в русском языке употребляется неопределенно-личная конструкция (п. 19).

4. Среди синтаксических трансформаций сложного предложения при переводе текста закона встречаются замена сложного предложения простым (п. 21). Встречается необходимость антонимического перевода, то есть лексико-грамматическая замена утвердительной конструкции на отрицательную с заменой одного из слов на его антоним (п. 18).

5. Эквивалентность текста оригинала и текста перевод может достигаться с помощью перераспределения семантических элементов между отдельными частями предложения.

\section{Список литературы:}

1. Алексеева И.С. Профессиональный тренинг переводчика / И.С. Алексеева: учеб. пособие. СПб.: СОЮЗ, 2001.

2. Бархударов Л.С. Язык и перевод (Вопросы общей и частной теории перевода) / Л.С. Бархударов. М.: «Международные отношения», 1975.

3. Комисаров В.Н. Лингвистика перевода / В.Н. Комисаров / Предисл. М.Я. Цвиллинга. Изд. 3-е. - М.: Книжный дом «ЛИБРОКОМ», 2009.

4. Соломатина С.Ю. Грамматические трансформации при переводе текстов с английского языка на русский (на материале английских эссе) / С.Ю. Соломатина // Вестник Удмуртского университета, 2016. Т.26, вып.6. С. 74-77. 


\title{
ЭКОНОМИЧЕСКИЕ НАУКИ
}

\author{
УДК 331 \\ РАЗВИТИЕ САМОЗАНЯТОСТИ НАСЕЛЕНИЯ КАК ПУТЬ РЕШЕНИЯ ПРОБЛЕМЫ \\ ЗАНЯТОСТИ
}

Исаев М.X.

аспирант базовой кафедры Торгово-промышленной палаты «Развитие человеческого капитала» ФГБОУ ВО «РЭУ им. Г.В. Плеханова»

\begin{abstract}
Аннотация. В статье освещены проблемы и перспективы развития самозанятости населения в РФ. Рассмотрены и обобщены современные теоретические подходы к самозанятости населения. Уточнено понятие самозанятого населения в современных экономических условиях. Определены основные причины возникновения самозанятости и перехода населения РФ к работе в условиях самостоятельной занятости, выявлены резервы роста численности самозанятого населения. Раскрыты особенности самозанятости в условиях информационного общества. Обоснована необходимость государственной поддержки развития самозанятости населения путем совершенствования системы регулирования отношений с субъектами бизнеса в указанной сфере.
\end{abstract}

Ключевые слова: занятость, самозанятость, предпринимательство, государственное регулирование.

Постановка проблемы. Обеспечение занятости населения является одной из ведущих проблем в условиях санкций и трудного положения в экономике. Во-первых, именно занятые создают ВВП государства, продуцируют необходимые обществу товары, продукты и услуги.

Во-вторых, занятость создает условия, с одного стороны, для реализации способностей и знаний, умений человека, то есть, его самореализации, а с другой, каждый человек получает возможность удовлетворения своих материальных, духовных и других потребностей через тот доход, что получает благодаря своей занятости.

Обеспечение занятости является предметом исследования учеными разных профессиональных направлений, представителями определенных научных школ, идеологами, политиками. Но ведущее место среди них занимает проблема занятости как комплекса особых функций, направленных на обеспечение развития и совершенствования хозяйственного механизма, постоянное обновление экономики хозяйствующих субъектов, создание инновационного поля деятельности, а также как одну из форм обеспечения самостоятельной занятости населения. Именно это направление социально-экономического развития становится предметом исследования не только ученых, но и тех, кого интересует возможность практического внедрения идей, связанных с различными аспектами осуществления предпринимательской деятельности.

Анализ исследований по данной проблеме. Проблемами самостоятельной занятости в контексте осуществления предпринимательской деятельности, занимались ведущие отечественные ученые экономисты: Н. Вишневской, Н. Волгина, Б. Генкина, И. Заславского и др.

Результаты исследований. Рыночная система с присущими ей формами собственности, свободой предпринимательства и свободой выбора, мотивацией с учетом личных интересов, конкуренцией и ценообразованием создает объективные основы для совершенствования различных организационно хозяйственных форм привлечения трудоспособного населения к процессу активной трудовой деятельности.

Одной из таких форм предпринимательства в современных условиях экономического развития является самостоятельная занятость населения. Самозанятость - относительно новое явление в отечественной экономике, которое начало развиваться в переходный период к рыночным условиям хозяйствования. В научной литературе и статистической практике различных стран понятие “самостоятельная занятость” и “самозанятость" используется для обозначения занятости без юридического оформления трудовых договоров. По определению Международной классификации статуса занятых (ICSE - 93) самозанятость означает работу на собственном предприятии, когда вознаграждение непосредственно зависит от дохода, полученного от производства продукции и услуг [1].

Самостоятельная занятость в рыночных условиях превращается в обязательный, объективно существующий элемент рыночных отношений. Ее развитие обусловлено действием ряда экономических и социальных факторов. С другой стороны, самозанятость в РФ была всегда (ведение личного подсобного хозяйства, подработки во время отпусков и после окончания основного рабочего дня, репетиторство и тому подобное). Рыночная экономика выводит самозанятость на новый уровень использования рабочей силы. Экономическая идеология рынка, прежде всего, предусматривает переход каждого трудоспособного к самообеспечению. Самостоятельная занятость населения постоянно присутствует в системе национальной экономики. Ее обычно определяют как форму предпринимательства на основании того, что в современной отечественной и зарубежной экономической литературе предпринимательство трактуется, прежде всего, 
как самостоятельная экономическая деятельность граждан, основанная на использовании собственных идей, рабочей силы и средств производства [1]. Благодаря развитию самостоятельной занятости, особенно в условиях трансформационной экономики, создаются дополнительные рабочие места, а также появляется возможность проявить собственную инициативу и получить доходы. Такая форма занятости не требует государственных капитальных вложений, имеет мобильную организационную структуру, базируется на сильной мотивации труда, ориентируется на потребности потребителя и оперативно удовлетворяет их.

Самозанятыми в РФ считаются те, кто сам обеспечивает и сам организует свою деятельность, которая служит им основным источником дохода, самостоятельно обеспечивает себя работой. К основным причинам перехода населения нашей страны к работе в условиях самостоятельной занятости, относятся:

-недостаточное количество средств для жизни;

-задержки с выплатой заработной платы и социальных трансфертов (пенсий, пособий), для работников бюджетной сферы - несвоевременная индексация тарифных ставок;

-потеря работы в результате увольнения (сокращение штатов, банкротство предприятий) - тем самым потеря основного источника формирования средств на существование [4];

-поиск более стабильного источника надлежащего по размеру дохода; поиск работы, что обеспечивает возможность самореализации, удовлетворения потребностей и амбиций, а также усиливает интерес к предпринимательству.

Значительная часть самозанятых занимается предпринимательством. Несостоятельность государства и отдельных работодателей обеспечить должное предложение рабочих мест приводит к расширению масштабов самозанятости населения.

К современным формам самозанятости как вида предпринимательства, возникших в условиях трансформации общества в глобальное информационное, относят предоставление деловых услуг, покупкупродажу через сеть Internet и Online услуги.

По данным компании Miniwatts Marketing Group, с 2012 года сектор Internet - услуг в РФ вырос в 25 раз. [3]. Глобальная сеть Internet предоставляет неограниченные возможности для осуществления электронной экономической деятельности, а это означает, что бизнес-процессы осуществляются мгновенно в любом месте по различным направлениям. Новая виртуальная организационная форма бизнеса возникла как необходимость обеспечения конкуренции за ограниченных ресурсов и финансов с целью скорейшей реализации запросов клиентов. Преимуществами такой формы занятости является сокращение времени и размера стартового капитала для открытия дела; устранение влияния географического фактора, возможность привлечения специалистов высокого уровня независимо от их места проживания;

-высокий уровень производительности труда;

- экономия затрат на помещение, транспорт;

- применение гибкой организации труда; скорость выполнения заказа;

-снижение барьеров при выходе на новые рынки [2].

Самостоятельная занятость является актуальной для лиц, которым свойственны такие черты, как активность, инициативность, настойчивость, готовность к риску и др. Однако развитие предпринимательства, в том числе, которое связано с самозанятостью в нашей стране осложняется многими причинами, к основным из них следует отнести нестабильность законодательства, регулирующего отношения собственности и налоговую систему. Необходимо обратить внимание и на то, что самостоятельная занятость населения может иметь и негативные проявления, а именно: неорганизованный, неуправляемый характер, что может вызывать ряд диспропорций. Кроме того, этот вид занятости, обычно, носит нелегитимный характер, не учитывается и не облагается налогами, что наносит значительные экономические потери государству. Все это свидетельствует о несовершенстве законодательной базы и недостаточное вмешательство государства в сферу предпринимательской деятельности в ее новых формах. Выводы. Самозанятость как конкретная форма особого вида экономической активности предпринимательства, обеспечивает части населения создание новых рабочих мест. Самозанятость как относительно автономный сегмент отечественной экономики обеспечивает улучшения показателей предпринимательской деятельности. Разработка конкретных организационно - экономических инструментов поддержки развития самозанятости должна осуществляться последовательно. Первоочередной задачей в этой сфере является внедрение региональных стратегий поддержки самозанятости, составными элементами которых должны быть:

-разработка документов нормативно - правовой регламентации деятельности самозанятых граждан;

-определение приоритетных сфер приложения труда;

-разработка территориальных программ содействия развитию микробизнеса;

-финансово - кредитное регулирование, снижение уровня риска. Следующим шагом должно стать совершенствование организационно - экономического механизма взаимодействия предпринимателей с местными органами власти, что должно направлять к легализации неформальной занятости и детенизации занятости, оптимизации налоговых платежей и конструирование системы социальной защиты самозанятых. Проблемы самозанятости требуют дальнейшего исследования, потому что в следствие перехода экономики к новому информационно - коммуникативного типа численность охваченных этой формой занятости в будущем будет расти. 


\title{
Список источников литературы
}

1.Абрамова Е. А. Кризисная самозанятость в России: классификация, структура и уровни развития // Современные наукоёмкие технологии. Региональное приложение. - Иваново : Изд-во Ивановского государственного химико-технологического университета. - 2012. - № 4. - С. 7.

2.Бубновская Т. А. Самозанятость в российском туризме как способ импортозамещения в данной отрасли // Туризм: право и экономика. - 2015. - № 3. - С. 25-28.

3.Козачун Г. У., Легчилина Е. Ю. Самозанятость как направление государственной политики в области управления человеческими ресурсами в инновационном предпринимательстве // Вестник Сибирской автомобильно-дорожной академии (Омск). - 2012. - № 4. - С. 134.

4 Киреенко А. П., Климова М. О. Самозанятость населения и теневой рынок труда в России // Проблемы экономики. - 2015. - № 3. - С. 9-12.

УДК 656.073

\section{ПЕРСПЕКТИВЫ ПЕРЕВОЗОК СКОРОПОРТЯЩИХСЯ ГРУЗОВ В РОССИИ}

Эглит Я.Я.

д.m.н.,профессор,заведующий кафедрой УТС

ГУМРФ им.адм. С.О.Макарова;

Андорская А.В.

ст.преподаватель кафедры УТС

ГУМРФ им.адм. С.О.Макарова

Шаповалова М.И.

доцент кафедры УТС

ГУМРФ им.адм. С.О.Макарова

\section{PROSPECTS OF TRANSPORTATION OF PERISHABLE GOODS IN RUSSIA}

Ya. Ya. Eglit

$D t S$, Professor, head of department TSM

Admiral Makarov State University of Maritime and Inland Shipping

A.V.Andorskaya

senior lecture of department TSM

Admiral Makarov State University of Maritime and Inland Shipping

M.I. Shapovalova

PhD, docent of department TSM

Admiral Makarov State University of Maritime and Inland Shipping

\begin{abstract}
Аннотация. Рассмотрены перспективы перевозок скоропортящихся грузов морским транспортом, а также проблемы, возникающие в процессе транспортировки и пути их решения. Для повышения эффективности перевозок скоропортящихся грузов предложена система использования функционала 5 plпровайдера от перевозчика; использование e-commerce, включая оплату за хранение и демередж контейнеров кредитной картой; переход на сжиженный природный газ как новое экологическое топливо, соответствующее требованиям с 2020 года. А также необходимость в использовании последних информационных технологий, таких как применение rsm/traxens-технологии - системы gsm-слежения за реф-контейнерами и усовершенствования процессов перевозки.

Annotation. Considered the prospects of transportation of perishable goods by sea, as well as the problems arising in the process of transportation and ways to solve them. To improve the efficiency of transportation of perishable goods, a system of using the functionality of 5 Pl-provider; using e-commerce, including payment for storage and demurrage by credit card; using LPG as a new eco-fuel, which corresponds to new requirements of 2020 year. As well as the necessity to use high top information technology as RSM/TRAXENS-system of GSM-following up the units and improvement of transport processes.
\end{abstract}

Ключевые слова: морской вид транспорта, 5-pl провайдер, peф-установка Jen-Set, информационные технологии в логистике, СПГ, е-сommerce, RSM/TRAXENS - технологии.

Keywords: sea transport, 5-pl provider, Jet-Set, information technology in logistics, LPG fuel, e-commerce, Remote Container Management, TRAXENS - technologies.

Введение.

Российская Федерация - государство, обладающее крупнейшей в мире территорией. Транспортная система России характеризуется развитой транспортной сетью, одной из наиболее обширных в мире. [1] В транспортной сфере занято свыше 3,2 млн. человек, что составляет 4,6 \% работающего населения по данным 2019 года.

В статье рассмотрены: основные проблемы, возникающие в процессе транспортировки скоропортящихся грузов и инновационные методы их решения. 
Данная тема актуальна в связи с непрекращающимся экономическим кризисом в России, необходимостью сокращением издержек на логистику недешевых скоропортящихся грузов, сокращением времени на отслеживание доставки контейнеров, своевременной подачи информации о состоянии температурного режима и наличии пломбы на контейнере, а также защиты окружающей среды, путем использования сжиженного природного газа в контейнерных морских перевозках.

Таким образом, целью работы является изучение практических аспектов в области организации доставки скоропортящихся грузов.

Объект исследования - проблемы организации доставки скоропортящихся грузов.

Предмет исследования - пути решения проблем организации скоропортящихся грузов.

В соответствии с поставленной целью определены следующие задачи:

1) определить основные проблемы доставки скоропортящихся грузов;

2) назвать и описать пути решения данных проблем.

1. Проблемы организации доставки скоропортящихся грузов

Перевозка скоропортящихся продуктов в прямых смешанных сообщениях является наиболее экономичной и прогрессивной. На сегодняшний день существуют преимущественно железнодорожноводные, автомобильно-водные и железнодорожно-автомобильные перевозки скоропортящихся грузов. При перевозках скоропортящихся грузов в прямом смешанном сообщении к документам обязательно прилагаются сертификаты или удостоверения качества. В этих документах кроме информации, описывающей состояние перевозимых грузов, указывают сроки возможной транспортировки с учетом условий перевозки на конкретных видах транспорта. [2]

Говоря о морском транспорте, REFконтейнер предназначен для перевозки любых видов скоропортящихся грузов на любые расстояния. Его отличительной особенностью является тот фактор, что температура в REFконтейнере поддерживается на постоянном уровне в течение всего времени следования. Это гарантирует сохранение температуры груза на том уровне, который он имел при погрузке. [4] REFконтейнер используется для перевозки замороженных и охлажденных грузов (мяса, рыбы, полуфабрикатов), свежих фруктов и овощей, медикаментов, химикатов, цветов и других. Для перевозки скоропортящихся грузов используются следующие виды рефрижераторов -20, -40 футовые стандартные рефконтейнеры, -40 футовые высокие рефконтейнеры, -45 футовые высокие рефконтейнеры. Поддержание температуры груза в пути следования в необходимом диапазоне обеспечивается за счет теплоизоляции контейнера и запаса тепловой энергии при погрузке груза. Вследствие этого контейнеры-термосы имеют ограничения по срокам и дальности перевозки в них грузов. В контейнерах-термосах могут перевозиться различные скоропортящиеся грузы, например, пиво, соки, напитки и другие скоропортящиеся и термочувствительные грузы, за исключением свежих овощей и фруктов. Эти грузы, как правило, предварительно охлаждены или нагреты, хотя могут быть и термически не обработаны. Необходимый температурный режим транспортировки поддерживается посредством следующих факторов:

1) теплоизоляционных материалов и специальной конструкции поверхностей (стен, пола и потолка) контейнера;

2) системы вентиляции;

3) непосредственно системы охлаждения (нагрева). [3]

Серьезное влияние на технологию перевозок скоропортящихся грузов оказывает:

1) погодные условия и сезонность;

2) неравномерность погрузки грузов, связанная с неритмичным подходом судовых партий;

3) отсутствие встречных грузопотоков, приводящее к значительным порожним пробегам изотермического подвижного состава[5].

Уменьшение объемов перевозок связано, безусловно, с сокращением производства продуктов питания в России, а также импорта этой продукции в условиях экономического кризиса.

В настоящее время развитию перевозок скоропортящихся грузов препятствует ряд проблем, требующих совместного решения всеми участниками транспортного рынка, а именно:

1) отсутствие должного инвестирования в информационные технологии в логистике, такие как GSMслежение за контейнерами;

2) несоответствие структуры портов и терминалов России для использования TRAXENSтехнологий/RSM;

3) физическое старение и исключение из эксплуатации по истечению срока службы контейнеров, невосполняемость REFконтейнерами смарт-рефами нового поколения;

4) отсутствие контроля качества находящихся в эксплуатации реф-контейнеров;

5) дефицит REFконтейнеров с надлежащими теплотехническими качествами, а также цистерн для перевозок наливных продовольственных грузов;

6) усилением экологических требований в сфере морских перевозок и регулирования выбросов вредных веществ в Мировом океане;

7) экономическая целесообразность переключения на СПГ с нефтепродуктов;

8) медленное создание бункеровочной инфраструктуры. 
Таким образом, можно сделать вывод о том, что перевозка скоропортящихся грузов в прямых смешанных сообщениях является наиболее экономичной и прогрессивной, так как, объединив положительные стороны каждого вида транспорта, можно получить наиболее выгодную либо оптимальную цепь поставок. Исходя из трудов Вальта Эрвина Бруновича следует, что в рефрижераторах температурный режим транспортировки поддерживается посредством таких факторов, как теплоизоляционные материалы и специальная конструкция поверхностей (стен, пола и потолка); системы вентиляции и непосредственно системы охлаждения (нагрева).

2. Пути решения проблем организации доставки скоропортящихся грузов

К 2020 году прогнозируется дальнейшее понижение объемов перевозок RЕFгрузов морским транспортом ввиду затяжного экономического кризиса. В отношении мяса птицы и свинины ожидается существенное (почти в 3 раза или на 500 тыс. тонн к уровню 2008 года) снижение объемов перевозок морским транспортом. Причиной этого будет служить импортозамещение, вызванное рядом санкций в отношении РФ, установленное в 2014 году.

В настоящее время приоритетная задача - кардинально изменить ситуацию, обеспечив условия для привлечения перевозок скоропортящихся грузов. Для этого:

1) повышается эффективность использования отключенных REFконтейнеров за счет организации перевозок непродовольственных грузов обратно по маршруту в так называемых NOR-ax.;

2) внедряются современные информационные технологии при оформлении перевозки груза такие как отслеживание температурного режима в режиме реального времени; отправка сообщений перевозчику о растарке, затарке, наличию пломбы и ЧП во время движения REFконтейнера;

3) реализованы предложения по новому порядку расчета сроков доставки грузов в рефконтейнерах, перевозимых на прямую на склады получателей за счет предоставления дверного, экспедиторского и таможенного сервиса, тем самым реализации себя как 5-PL провайдера - своеобразная added value service. Использование охлаждающей системы Jenset позволило существенно увеличить дальность перевозок грузов в рефконтейнерах;

4) применение е-соmmerce систем позволило сократить время ожидания на документацию, рассылку счетов, котировку ставок и тарифов, расчет транзитного времени.

Вследствие морального и физического старения используемых в настоящее время транспортных средств, а также прогнозируемого изменения в структуре спроса замороженных грузов и фруктов, для обеспечения возможности перевозок скоропортящихся грузов в период 2020-2030 гг. необходимо внедрение новых технологий перевозок, соответствующих изменениям потребностей рынка и использующих современные достижения научно-технического прогресса[6]. Это требует разработки и создания принципиально новых технологий в REFконтейнерах на базе существующих перспективных разработок в области конструкции вентиляции и работы JenSet, используемого на дальние расстояния для поддержания необходимой температуры. С учетом того, что в рассматриваемой перспективе в соответствии с вышеизложенными прогнозами развития рынка для перевозок скоропортящихся грузов будут использоваться в основном REFконтейнеры, необходима их доработка. В этом случае общая сумма инвестиций в обновление парка контейнеров для перевозок замороженных и охлажденных грузов составит около 32 млрд. руб. в ценах 2019 года. Для развития транспортной логистики помимо эффективного функционирования собственно транспорта необходимы современные перегрузочные комплексы, с системами подключения RSM/TRAXENS - технологии, которая позволяет подключать все контейнеры на борту к единой информационной сети и всегда быть на связи с коммуникационным центром. Где бы ни находился контейнер на судне, центр будет располагать самой свежей информацией о нём. Собранные данные будут поступать в головной офис перевозчика. Связавшись с офисом, отправители и получатели грузов, а также сотрудники страховых компаний смогут в режиме реального времени узнать, что происходит c их REFконтейнеры. RSM/Traxens предоставляет исчерпывающую информацию о положении, температуре, влажности, вибрации, физическом воздействии и непредусмотренном вскрытии контейнера. Технология может стать настоящей находкой для рефрижераторных перевозчиков, поскольку предоставляет возможность контроля и удалённого изменения температуры в контейнерах. Применение RSM/Traxens также существенно облегчит работу инспекторов во время плановых проверок [7].

Поэтому в целях эффективного развития перевозок скоропортящихся грузов необходимо работать в следующих направлениях:

1) создание новых портов, хабов и терминалов для подхода океанских судов с осадкой до 16 метров глубиной и вместимостью 22000 TEUS, а также своевременной электронной их обработки;

2) совершенствование нормативно-правовой базы, участие в разработке основных отраслевых законов и технических регламентов на едином мировом уровне;

3) расширение перечня услуг (added value service) - экспедирования и предоставления сервиса таможенной очистки от основных игроков контейнерного бизнеса, предоставляемых конечным пользователям, своеобразный переход к системе 4 и 5-PL провайдеров;

4) активизация создания и продвижения на рынке RSM/TRAXENS-технологий; 
5) развитие контейнерных перевозок скоропортящихся грузов путем глобализации и укрупнения морских линий в выгодные альянсы, тем самым увеличивая сетку покрытия земного шара и сокращения издержек в логистике;

6) полный переход на e-commerce (электронная документация, оплата по карте, использование приложения на телефоне, получения push-уведомления об изменениях контейнера, обеспечивающей рост перевозок как на внутреннем, так и на международном транспортном рынке[8];

7) полный переход на СПГ.

Исходя из вышеизложенного, существует ряд направлений, которые будут способствовать эффективному развитию и помогут решить проблемы организации доставки скоропортящихся грузов. Для этого всем участникам транспортного рынка необходимо сконцентрировать свое внимание на повышении качества перевозок скоропортящихся грузов за счет внедрения прорывных, инновационных научнотехнических решений и совершенствования взаимодействия субъектов перевозочного процесса.

Заключение.

В работе зучены проблемы доставки скоропортящихся грузов и пути их решения. Также, отмечано, что серьезное влияние на технологию перевозок скоропортящихся грузов оказывают: погодные условия и сезонность, неравномерность погрузки грузов, связанная с неритмичным подходом судовых партий; отсутствие встречных грузопотоков, приводящее к значительным порожним пробегам реф-контейнеров.

Определен ряд проблем, препятствующих успешной транспортировке скоропортящихся грузов. В настоящее время приоритетная задача - кардинально изменить ситуацию, обеспечив условия для их привлечения. Для этого повышается эффективность использования REFконтейнеров за счет организации перевозок непродовольственных грузов, внедряются современные информационные технологии при оформлении перевозки груза, реализованы предложения по новому порядку расчета сроков доставки грузов в REFконтейнерах до двери клиента, использование RSM/TRAXENS технологии и предоставления сервиса 5-Pl провайдера. Это позволит существенно уменьшить время, сократить затраты и увеличить объем перевозок и дальность перевозок грузов в рефконтейнерах.

Перевозки скоропортящихся грузов являются одним из наиболее высокодоходных секторов транспортного бизнеса и не следует допускать их снижения. Для этого всем участникам транспортного рынка необходимо сконцентрировать свое внимание на повышении качества перевозок скоропортящихся грузов за счет внедрения прорывных, инновационных научно-технических решений и совершенствования взаимодействия субъектов перевозочного процесса.

\section{Список литературы}

1. Википедия. Свободная энциклопедия [Электронный ресурс]. - Режим доступа: https://ru.wikipedia.org/wiki/Транспортная_система_России

2. Экономическая библиотека [Электронный ресурс]. - Режим доступа:

http://eclib.net/6/30.html

3. Вальт Э.Б. «Организация перевозок скоропортящихся грузов». - Е.: УрГУПС, 2000. - 365 с.

4. Эглит Я.Я. «Управление транспортными системами».- СПБ.: Феникс, 2004.-424c.

5. Русинов И.А. «Обработка и хранение рефрижераторных грузов на специализированных терминалах». - СПБ.:Издательство Санкт-Петербургского Института Истории РАН «Нестор-История», $2005.168 \mathrm{c}$.

6. https://www.maersk.com/news/2018/12/13/new-maersk-products-services (статья опубликована на английском 13/12/2018)

7. https://www.msc.com/rus/sustainability

8. https://www.cma-cgm.com/products-services/ecommerce 


\title{
ЮРИДИЧЕСКИЕ НАУКИ
}

\section{СОВРЕМЕННЫЕ ПРОБЛЕМЫ ПРАВОПРИМЕНИТЕЛЬНОЙ ДЕЯТЕЛЬНОСТИ В СФЕРЕ УГОЛОВНО-ПРАВОВОЙ ОХРАНЫ ПРАВ И ИНТЕРЕСОВ НЕСОВЕРШЕННОЛЕТНИХ С ПОЗИЦИЙ ВВЕДЕНИЯ «УГОЛОВНОГО ПРОСТУПКА» В ДЕЙСТВУЮЩЕЕ УГОЛОВНОЕ ЗАКОНОДАТЕЛЬСТВО}

\author{
Кулинич Валерий Валериевич \\ магистрант ФГБОУ ВО «Кубанский \\ государственный аграрный университет им. И.Т. Трубилина» \\ Белова Светлана Леонидовна \\ юрист ООО «Юридическая компания \\ «Юридический Советник Кубани» («ЮК «ЮСК») \\ Научный руководитель \\ Чапурко Татьяна Михайловна \\ д-р полит. наук, к.ю.н., профессор \\ 2. Краснодар
}

Современный прогноз преступности в отношении несовершеннолетних и малолетних выглядит неутешительным, так как существенные положительные изменения социально - экономических и политикоправовых условий в стране не реализованы с позиций необходимости и требовательности в данной сфере.

Вместе с тем методы правоприменительной деятельности в противодействии преступлений, совершаемых против несовершеннолетних и малолетних, должны определяться и осуществляться на основе принципа сочетания профилактики правонарушений [1], предупреждения преступлений (часть 1 статьи 2 УК РФ) и реализации уголовной ответственности. Основой такому системному подходу должна быть как можно более обширно-обеспеченная уголовно-правовая охрана прав и интересов общества относительно несовершеннолетних и малолетних лиц от преступных деяний, совершаемых взрослыми лицами.

По данному вопросу Конституционный Суд РФ и Верховный Суд РФ неоднократно излагали свои позиции, в том числе и относительно изменений в уголовное законодательство последнего времени в проект Ф3 «О внесении изменений в Уголовный кодекс Российской Федерации и Уголовно - процессуальный кодекс Российской Федерации в связи с введением понятия уголовного проступка»[2].

Однако в соответствии с предложениями о введении в действующее уголовное законодательство понятия «уголовный проступок» видится несколько проблематичным осуществление уголовно-правовой охраны прав и интересов несовершеннолетних от преступных посягательств взрослых лиц, так как предлагаемые в законопроекте условия разделения «преступлений» и «уголовных проступков» связаны в соответствии со статьей 14 УК РФ с преступлениями небольшой тяжести, которыми признаются умышленные и неосторожные деяния, за совершение которых максимальное наказание, предусмотренное уголовным законодательством, не превышает трех лет лишения свободы.

Подобная «гуманизация уголовного законодательства путем декриминализации определенных деяний, введения составов преступлений с административной преюдицией, расширения сферы применения института освобождения от уголовной ответственности» может привести в итоге к ослаблению или прямому отсутствию уголовно-правовой охраны прав и интересов малолетних и несовершеннолетних лиц от преступных действий взрослых лиц.

Тем более что актуализируются давние проблемы науки уголовного права связанные с оценкой соразмерности деяния и ответственности, что должно соблюдаться как на внутриотраслевом, так и межотраслевом уровнях при различных вариантах закрепления взаимосвязи уголовного права с другими отраслями права. Уголовная ответственность - самая карательная из всех видов ответственности и применяться должна только тогда, когда никакая из более легких мер не даст необходимого эффекта.

В связи с этим, есть необходимость обратить внимание на правоприменительные проблемные относительно положений диспозиции части 1 статьи 151 УК РФ, содержание которой таково, что перечень антиобщественных действий, вовлечение в которые несовершеннолетнего является преступлением, должен считаться исчерпывающим.

Однако в практической деятельности выявляются факты вовлечения несовершеннолетних в иные антиобщественные действия, которые по опасности разлагающего влияния на несовершеннолетних не уступают тем, что указаны законодателем.

К таким, в частности, можем отнести:

- использование труда несовершеннолетних при культивировании запрещенных к возделыванию растений (конопли, мака и других растений, содержащих наркотические вещества);

- использование труда несовершеннолетних как в притонах для потребления наркотических или психотропных веществ, так и в притонах для занятий проституцией, совершенные родителем или иным лицом, на которое законом возложены обязанности по воспитанию несовершеннолетнего. 
Детский труд пользуется большим спросом ввиду его дешевизны, а также ввиду того, что дети являются, естественно, более робкими, более послушными, чем взрослые, а также слишком запуганы, чтобы жаловаться. Детский труд, зачастую тяжелый и опасный, непоправимо подрывает здоровье детей, лишает их образования и обычных детских радостей. Работа, выполняемая детьми, зачастую сопряжена с травматизмом и искажением понятия о работе как об освобождающей силе или как об одном из средств возмужания.

В этом смысле, очевидно, что дать в законе исчерпывающий перечень антиобщественных действий, вовлечение в совершение которых способно искалечить психику несовершеннолетних, побудить их или приобщиться к совершению преступлений, невозможно. Поэтому возможно дополнить перечень в части 1 статьи 151 УК РФ указанием на «иные антиобщественные действия».

Далее, по степени общественной опасности отрицательного влияния на несовершеннолетних, к преступлениям, предусмотренным статьями 150 и 151 УК РФ, приближаются деяния взрослых лиц, совершенные в соучастии с несовершеннолетними. Речь идет о соучастии, инициатива в котором принадлежит самим несовершеннолетним (иначе будет вовлечение несовершеннолетнего в совершение преступления). Отрицательное, побуждающее к преступлениям влияние на несовершеннолетних в таких случаях заключается в укреплении их антиобщественного отношения к охраняемым законом интересам, что, несомненно, является весьма опасным нарушением общественного долга взрослых лиц по отношению к нравственному развитию несовершеннолетних. При соучастии с взрослым лицом несовершеннолетний получает достаточно большой опыт криминального поведения.

В такого рода объединениях создаются более благоприятные для обмена информацией и передачи социального опыта (в том числе, негативного), для эффективного решения общих групповых задач и стимуляции активности членов группы. Такие действия взрослых причиняют значительный вред нормальному развитию подростков, ведут к тому, что они вступают на преступный путь.

Однако никаких правовых форм, усиливающих уголовную ответственность взрослых лиц за совершенное преступление в соучастии с несовершеннолетними, действующий Уголовный кодекс РФ - не содержит. И это, конечно, пробел, который необходимо восполнить - включив в перечень обстоятельств, отягчающих наказание (статьи 63 УК РФ), указание на «совершение преступления взрослым лицом в соучастии с несовершеннолетним».

Так, по данным выборочного исследования 145 уголовных дел о преступлениях, совершенных смешанными группами, предварительному следствию и суду удалось доказать факт вовлечения несовершеннолетнего в совершение преступления лишь по 37 уголовным делам (24,5\%). По остальным 108 уголовным делам (75,5\%) взрослые преступники признавались как соучастники преступлений. И за период 2000 - 2016 гг. число таких ежегодно регистрируемых преступлений возросло в 2,5 раза [3].

Таким образом, явно прослеживается сокрытие преступных действий взрослых лиц, использующих в своих целях несовершеннолетних и малолетних лиц.

Далее, в правоприменительной деятельности заметное место занимают преступления, совершаемые взрослыми лицами в преступных и иных антиобщественных интересах несовершеннолетних, а именно, нередки факты покупки у несовершеннолетних похищенных ими вещей, предметов или угнанных автомобилей. И опасность отрицательного влияния указанных преступных контактов взрослых лиц на несовершеннолетних очевидна. Они укрепляют антиобщественное отношение несовершеннолетних к окружающим и тем самым побуждают их к совершению преступлений или иных антиобщественных действий.

К сожалению, Уголовный кодекс России прошел мимо и этой проблемы.

Но указанный пробел может быть восполнен двумя путями:

во-первых, дополнением перечня обстоятельств, отягчающих наказание (статья 63 УК РФ), указанием на совершение преступления в антиобщественных интересах несовершеннолетнего лица;

во-вторых, включением в статьи Уголовного кодекса РФ, предусматривающие преступления (которые часто совершаются в антиобщественных интересах несовершеннолетних), квалифицирующего признака, усиливающего санкцию за такое деяние, а именно, целесообразно: 1) дополнить часть 2 статьи 175 УК РФ пунктом «г) приобретение указанного имущества у несовершеннолетнего лица или сбыт его несовершеннолетнему лицу»; 2) дополнить часть 3 статьи 175 УК РФ - «а также приобретение автомобиля, заведомо добытого преступным путем у несовершеннолетнего лица, либо сбыт такого автомобиля несовершеннолетнему лицу»; 3) дополнить часть 2 статьи 222 УК РФ - «а также если в результате указанных деяний огнестрельное оружие, боеприпасы, взрывчатые вещества или взрывные устройства были получены у несовершеннолетнего лица либо переданы несовершеннолетнему лицу»; 4) дополнить часть 3 статьи 228 УК РФ пунктом «г) в отношении наркотических средств или психотропных веществ, переданных несовершеннолетнему лицу или полученных от несовершеннолетнего лица».

Далее необходимо обсудить вопрос об отрицательном воздействии на детей религиозных или общественных объединений, деятельность которых сопряжена с насилием над гражданами или иным причинением вреда их здоровью. Ответственность за создание такого религиозного или общественного объединения предусмотрена статьей 239 УК РФ - Создание некоммерческой организации, посягающей на личность и права граждан. 
Указанная уголовно-правовая норма формально противоречит статье 14 Декларации прав и свобод человека и гражданина, которая гласит, что «... каждому гарантируется свобода совести, вероисповедания, религиозной или атеистической деятельности. Каждый вправе свободно исповедовать любую религию или не исповедовать никакой, выбирать, иметь и распространять религиозные либо атеистические убеждения и действовать в соответствии с ними при условии соблюдения закона»[4].

Конституция Российской Федерации гарантирует свободу вероисповедания (статья 28) [5], однако, с другой стороны, государство должно ограждать своих несовершеннолетних граждан от религиозных и других организаций, исповедующих насилие и жертвоприношение или имеющих экстремистскую направленность. Вовлечение подростков в такие религиозные секты наносит обществу и государству значительный вред, так как состояние интеллекта, психики малолетних и несовершеннолетних сознательно приводится к культовому послушанию и в конечном итоге к деградации. Нередко культовые обряды связаны с жертвоприношением и в этом случае страшна как сама сцена и ситуация убийства, так и то, что подросток участвует в жертвоприношении.

Практика показывает, что родители зачастую совместно со своими несовершеннолетними детьми вовлекаются в такого рода объединения. Однако ответственность за вовлечение в них малолетних и несовершеннолетних законом не предусмотрена, видимо, законодатель не видит различия по характеру и степени общественной опасности указанного деяния, как в отношении взрослого, так и в отношении детей. Очевидна необходимость внесения в статью 239 УК РФ - части 4 следующего содержания - «4. Те же действия, совершенные с привлечением малолетних и несовершеннолетних лиц».

Сегодня, как никогда, необходимо в практической деятельности правоохранительных органов активизировать работу по выявлению и пресечению фактов преступного воздействия взрослых лиц на права и интересы несовершеннолетних и малолетних лиц.

\section{Список литературы:}

1. Об основах системы профилактики правонарушений в Российской Федерации: Федеральный закон от 23 июня 2016г. №182-Ф3 // Российская газета. 2016. 25 июня.

2. О внесении в Государственную Думу Федерального Собрания Российской Федерации проекта федерального закона «О внесении изменений в Уголовный кодекс Российской Федерации и Уголовнопроцессуальный кодекс Российской Федерации в связи с введением понятия уголовного проступка»: постановление Пленума Верховного Суда Российской Федерации от 31.10.2017г. № 42 [Электронный pecypc].

resolutions_plenum_supreme_court_russian\&year=2017

URL:http://www.supcourt.ru/documents/own/?category=

3. Статистические сведения ГУ МВД по Краснодарскому краю за 2016 год.

4. Декларация прав и свобод человека и гражданина. -М., ТОО «Иван». 1993.

5. Конституция Российской Федерации, принятая референдумом 12 декабря 1993г. / Российская газета. 1993. 25.12. 


\section{НАУЧНЫЙ ЖУРНАЛ \\ "GLOBUS" МУЛЬТИДИСЦИПЛИНАРНЫЙ \\ СБОРНИК НАУЧНЫХ ПУБЛИКАЦИЙ}

УДК 082

ББК 94.3

ISSN: 2658-5197

Редакционная коллегия:

Кежинбаева.А.М канд. экон. наук профессор

Фролов М.Г канд. мед. наук Научный сотрудник

Гамбарян.О,А д-р психол. наук Старший научный сотрудник

Максимов В.П канд. техн. наук Преподаватель

Герман А.О доцент

Сборник публикаций научного журнала "Globus" «Достижения и проблемы современной науки» г. Санкт-Петербурга: сборник со статьями (уровень стандарта, академический уровень). - С-П. : Научный журнал "Globus", 2019. $-216 \mathrm{c}$.

Тираж - 300 экз.

УДК 082

ББК 94.3

ISSN: $2658-5197$

Издательство не несет ответственности за материалы, опубликованные в сборнике. Все материалы поданы в авторской редакции и отображают персональную позицию участника конференции.

Контактная информация организационного комитета конференции:

Научный журнал "Globus"

Электронная почта: info@globus-science.ru

Официальный сайm: www.globus-science.ru

г. Санкт-Петербург- 2019

(C) Научный журнал "Globus" 